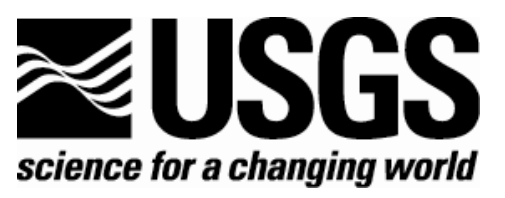

\title{
Type Region of the lone Formation (Eocene), Central California: Stratigraphy, Paleogeography, and Relation to Auriferous Gravels
}

\author{
By Scott Creely and Eric R. Force ${ }^{2}$
}

\section{Open-File Report 2006-1378}

2007

Any use of trade, firm, or product names is for descriptive purposes only and does not imply endorsement by the U.S. Government

U.S. Department of the Interior

U.S. Geological Survey

'San Jose State University (Emeritus), San Jose Calif.

${ }^{2}$ Center for Mineral Resources (U.S. Geological Survey and University of Arizona), Tucson Ariz. 


\section{Contents}

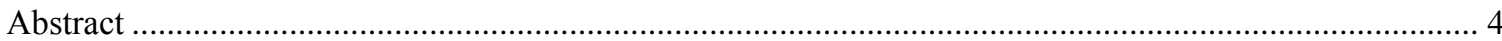

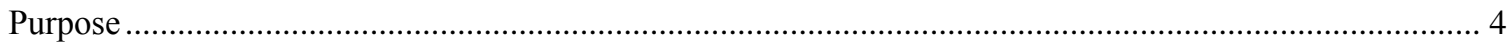

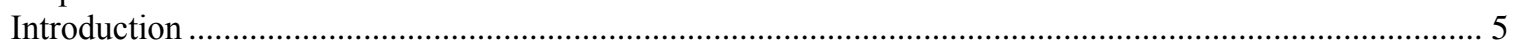

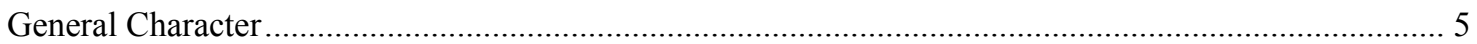

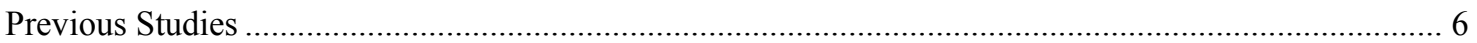

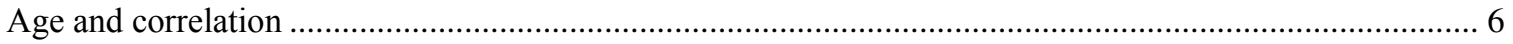

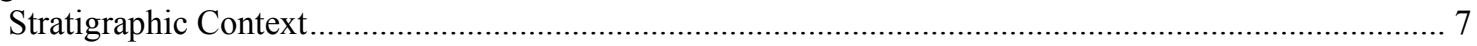

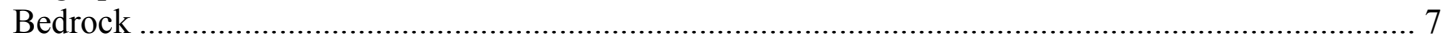

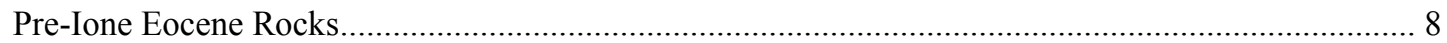

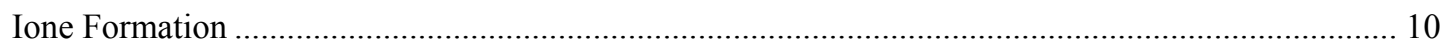

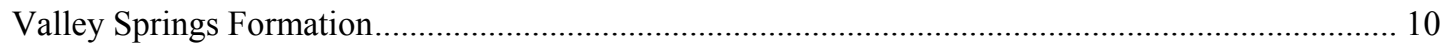

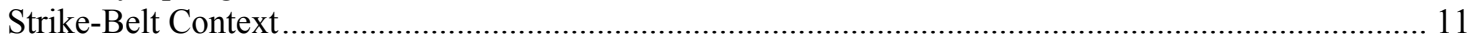

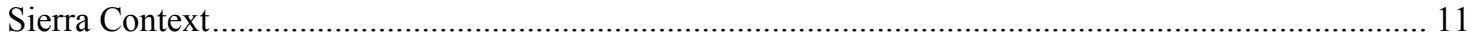

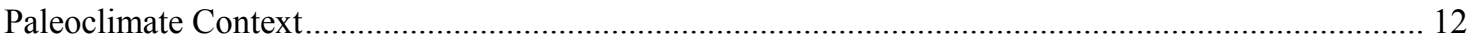

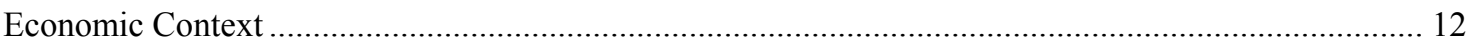

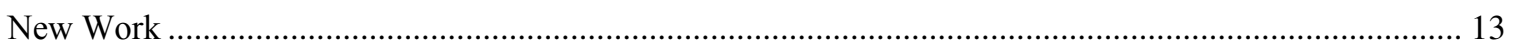

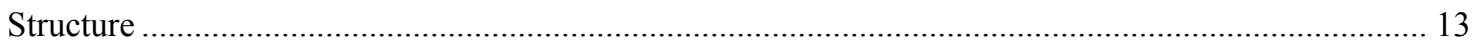

Depositional Setting: Description and Distribution of Facies ................................................................. 14

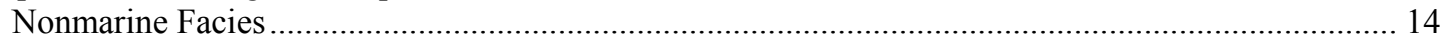

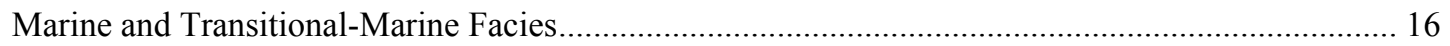

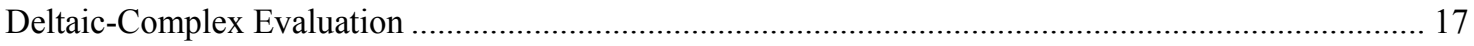

Paleontological Evidence for Marine/Estuarine Deposition ............................................................. 18

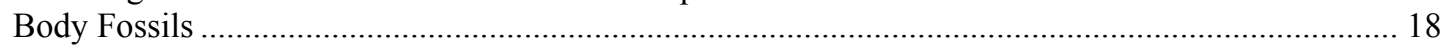

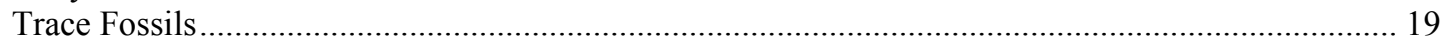

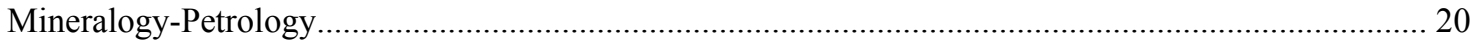

New Stratigraphic Framework.................................................................................................... 22

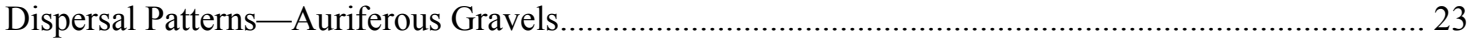

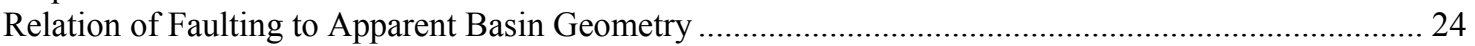

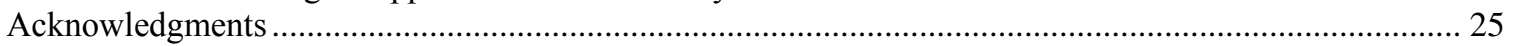

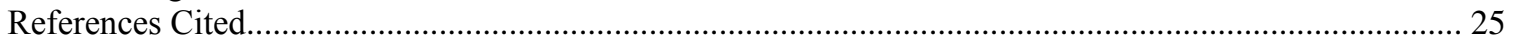

\section{Table}

Table 1. Generalized character of specimens of Ione Formation as functions of stratigraphic level and areal

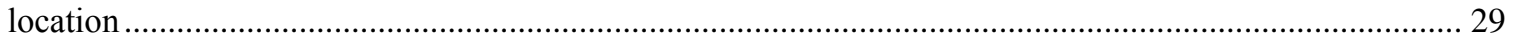

\section{Figures}

Figure 1. Surface distribution of the Ione Formation in central and northern California. ........................... 30

Figure 2. Areal geologic map of the Ione Formation in its type area, from Wagner and others (1981)...... 31

Figure 3. Mineral deposits of the type area of the Ione Formation in relation to geology............................ 32

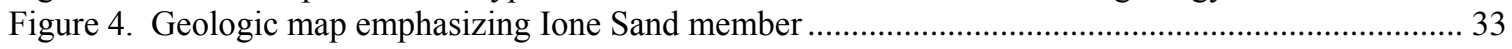

Figure 5. Generalized structure section across Ione Formation in type area. ............................................... 34

Figure 6. General stratigraphic column for western Amador County, California.......................................... 35

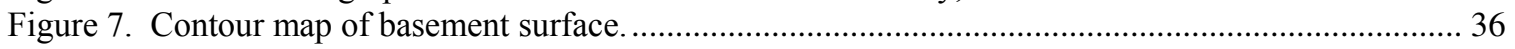

Figure 8. Geographic map of the type region of the Ione Formation ......................................................... 37

Figure 9. Structure contours on top of lower marine interval in the Ione area. ......................................... 38

Figure 10. Small normal-slip faults in shear zone .................................................................................. 39

Figure 11. Annotated photo of small tight anticline in thin-bedded shale and sandstone............................. 39

Figure 12. Diagram of maximum clast size of non-marine gravels .......................................................... 40

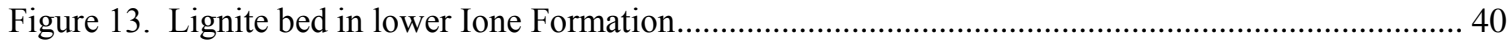

Figure 14. Unconformities, burrows, and low-angle cross-bedding in shoreline sandstone.......................... 41

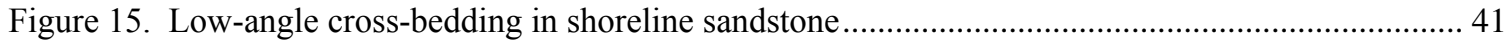

Figure 16. Structure contour map on the top of Ione Sand member.......................................................... 42 
Figure 17. North-south cross-section showing relation and extent of marine horizons........................... 42

Figure 18. Distribution of Ophiomorpha, other marine fossils, and glauconite .................................... 43

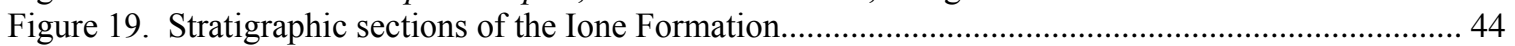

Figure 20. "Herringbone" cross-bedding in "hard orange sandstone" .............................................50

Figure 21. Clay drapes and rip-up clasts in sandstone................................................................... 50

Figure 22. Cast of Nuculana (?) in blocky tan mudstone near former calcining plant \#2 ........................ 51

Figure 23. Ophiomorpha burrow lined with dark clay showing knobby structure in sandstone ............... 51

Figure 24. Interior casts of Ophiomorpha burrows preserved as iron-oxide-cemented sand .................... 52

Figure 25. Ophiomorpha burrow with knobby structure within bedding of dark clay parting in

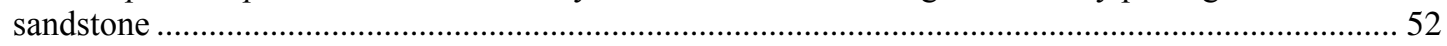

Figure 26. Thalassinoides (?) burrows in massive gray sandy mudstone........................................... 53

Figure 27. Relations of transitional-marine sand bodies in partial section of "hard orange sandstone"..... 53

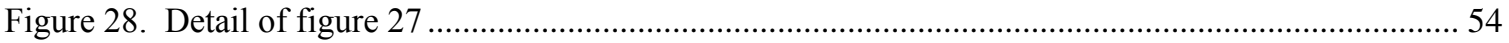

Figure 29. Bioturbated ("scrappy") sandstone with disruption of Fe-O-hardened layers........................ 54

Figure 30. Photomicrographs of Ione-Formation rocks.................................................................... 55

Figure 31. Structure sections through Ione Formation oriented generally east-west................................58

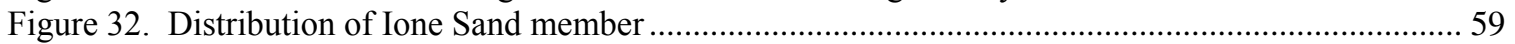

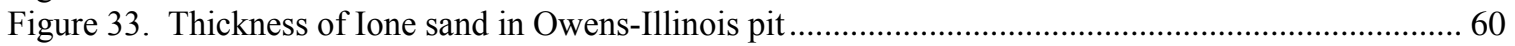

Figure 34. Irregular contact of shallow marine or estuarine deposits overlain by non-marine sandstone and conglomerate.

Figure 35. Structure-contour map on the top of the upper marine interval ("hard white sandstone")

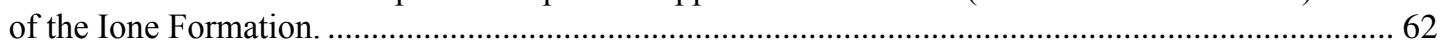

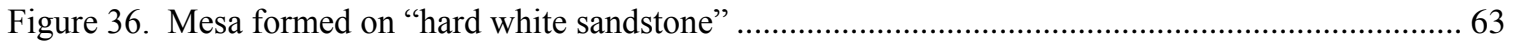

Figure 37. Waters Peak outlier, an erosion remnant of the Ione Formation ("hard white sandstone") ....... 63

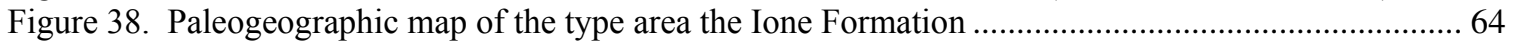

Figure 39. Hypothetical reconstruction of Eocene paleogeography of the type area of the Ione Formation 


\section{Abstract}

The middle Eocene Ione Formation extends over 200 miles $(320 \mathrm{~km})$ along the western edge of the Sierra Nevada. Our study was concentrated in the type region, 30 miles (48 $\mathrm{km}$ ) along strike. There a bedrock ridge forms the seaward western side of the Ione depositional tract, defining a subbasin margin. The eastern limit of the type Ione is locally defined by high-angle faults.

Ione sediments were spread over Upper Mesozoic metamorphic and plutonic bedrock, fed by gold-bearing streams dissecting the western slope of the ancestral Sierra Nevada. By middle Eocene time, a tropical or subtropical climate prevailed, leading to deep chemical weathering (including laterization) and a distinctively mature mineral assemblage was fed to and generated within Ione deposits. The Ione is noted for its abundant kaolinitic clay, some of it coarsely crystalline; the clay is present as both detrital grains and authigenic cement. Quartz is abundant, mostly as angular grains. Heavy mineral fractions are dominated by altered ilmenite and zircon. Distribution of feldspar is irregular, both stratigraphically and areally.

Non-marine facies are most voluminous, and include conglomerates, especially at the base and along the eastern margins of the formation where they pass into Sierran "auriferous gravels". Clays, grading into lignites, and gritty sands are also common facies. Both braided and meandering fluvial facies have been recognized.

Shallow marine waters flooded the basin probably twice. Tongues of sediment exhibiting a variety of estuarine to marine indicators are underlain and overlain by fluvial deposits. Marine body fossils are found at only a few localities, but burrows identified as Ophiomorpha and cf. Thalassinoides are abundant in many places. Other clues to marginal marine deposition are the occurrence of glauconite in one bed, typical relations of lagoonal to beach (locally heavy-mineral-rich) lithofacies, closed-basin threedimensional morphology of basinal facies, and high sulfur content of some marginal coals.

The Ione has been said to be deltaic; however the two transgressional-regressional cycles we propose imply that only the regressional parts were deltaic. At other times, much of the type Ione would better be termed an intertidal estuary. Because the lower marine sequence was deposited against a paleobasin margin on the west, deltaic morphology was constrained, but apparently progradation was from north to south despite drainage into the basin from the east. Relations to the south are unclear due to the Stockton arch. The eastern margin of the type-Ione basin, and to some extent even its marine facies, are poorly constrained. A surface on Sierran bedrock to the east may have been stripped of some Ione basinal facies, leaving only coeval entrenched fluvial channel deposits.

\section{Purpose}

The Ione Formation, due to its economic importance and its pivotal place in the evolution of geologic terranes in California, has been much discussed in the pertinent specialized literatures. No comprehensive description of the formation has appeared for 
over 50 years, however. This paper therefore addresses the Ione in its type area, in the hope of bridging these themes.

\section{Introduction}

The Ione Formation (Eocene) is "a distinctive sequence of clay-rich sedimentary rocks" (Glasmann and Wood, 1995) flanking the lower foothills of the western Sierra Nevada. It crops out as a narrow belt extending for approximately $320 \mathrm{~km} \mathrm{(200} \mathrm{mi)} \mathrm{from}$ north of Oroville (Oroville Table Mountain), on the Feather River, to Friant (near Fresno) on the south (fig. 1), dipping gently west.

The Ione Formation was named by Lindgren (1894) who stated: "During the Neocene period [the Ione was then believed to be Miocene] the auriferous gravels accumulated on the slope of the Sierra Nevada, and at the same time there was deposited in the gulf then occupying the Great Valley a sedimentary series consisting of clays and sands, to which the name Ione Formation has been given."

Turner (1894) described the Ione at the type locality, where he divided the formation into three members:

a. A lower white clay, in some places sandy, in others relatively pure (Turner mentioned that this clay was thought by some to have formed from rhyolite tuffs). b. Sandstone, usually white, but locally brick-red; in places contains white quartz pebbles, passing into conglomerates.

c. Clay rock, fine-grained, light-gray, with irregular fractures.

In an extensive regional study of the Ione Formation, Allen (1929) pointred out that the term Ione Formation "has been employed in a number of different ways and to include a variety of unrelated rock types": he proposed a redefinition of the term: "In the present paper, it is proposed to restrict the name Ione Formation to the beds along the foothills of the Sierra Nevada that have a mineral composition and history similar to the lower two members [previously listed by Turner, 1894] of the type locality."

\section{General Character}

The Ione Formation is dominantly siliciclastic. Clay is pervasive, both as clay rock and as matrix for sand or sandstone. In some sands, framework grains may be of clay (cf. Wood and others, 1995). Conglomerates are prominent in certain parts of the section, especially near the base. Several beds of lignite are present.

One hallmark of the Ione is its characteristic light color; white or near-white is typical. Locally, precipitation of iron oxides has rendered to these various hues of red, brown, or orange. Some of the mud rocks, including occasional shale, are rich in carbon and tend toward brown, and the lignites, of course, are dark brown or black.

The Ione is a relatively thin unit. In the type region (figs. 2 to 5), the largest thickness reported (excluding an apparently erroneous figure cited by Turner, 1894) is $190 \mathrm{~m}$ (630 feet) (Chapman and Bishop, 1975). Because the Ione is overlapped to the west by younger units, generally with slightly lesser dips, exposed parts of the Ione form westward-thickening wedges. 
Probable depositional environments are discussed below. Parts of the formation seem likely to be fluvial in origin. At least several parts, however, definitely represent marine or estuarine deposition.

\section{Previous Studies}

The Ione Formation has become the subject of a voluminous literature, much of it specialized in the following fields:

1) economic-mineralogic descriptions:

2) paleoclimatic influence on mineralogy;

3) environment of deposition; and

4) stratigraphic context to Great Valley units.

Such works will be referred to only as they pertain to our text. There are, however, relatively few comprehensive published areal-stratigraphic studies that cover the type area of the formation, and none of them are modern. The consequent need for an update led to the present study. We have no complaints about the studies currently in the literature, however; they gave us a valuable head start.

The extraordinary monograph by Allen (1929) is and should remain the most basic description of the Ione Formation, and emphasizes its type area as do we. Allen outlined the fundamental paleogeographic, paleoclimatic, stratigraphic, and mineralogic character of the formation.

The study by Pask and Turner (1952) is also of great value, as it includes a detailed stratigraphic study and geologic map (scale 1:12,000) of a central part of our study area. They divided the Ione into a lower more quartzose and clayey member and an upper more feldspathic member exposed south of Jackson Valley. The lower member they in turn divide into three units, of which the " upper lentil of clayey sand and sandy clay $\{$ is $\}$ locally called the Ione sand and Cheney Hill clay." Pask and Turner also included a study of clays and lignite in their lower member.

Chapman and Bishop (1975), though ostensibly a geophysical investigation, contributed tremendously to our knowledge of three-dimensional geometry and extent of the formation.

\section{Age and correlation}

The Ione Formation has long been regarded as middle Eocene. A limited molluscan fauna and an apparently firm correlation with the Domengine Formation (Coast Ranges and subsurface Great Valley) have led to this age assignment. However, lately, this correlation has been questioned. Ray Sullivan (San Fransisco State Univ., pers. comm., 2002), based on extensive study of well logs, interprets that the Ione is somewhat younger than the Domengine. Nevertheless, this would not preclude the Ione from being middle Eocene, as the Domengine lies well down in the Lutetian Stage (middle Eocene). Evidence presented below of marine transgressions into otherwise-non-marine Ione Formation in a non-marine Tertiary section would itself strongly suggest a middle Eocene age, as this is the time of greatest transgression in the Tertiary of the region (Bartow, 1991). 
If correlation to the west is uncertain, that to the east is unquestioned. The ties between the Ione and the so-called Tertiary "auriferous gravels" of the Sierra foothills have been widely accepted for some years. The concept of proximal Ione facies, with gravels marking the channels that served as the feeders for the finer-grained Ione sediments, is discussed in later sections.

The Ione seems to be readily recognized, based on lithology alone, over its entire $320 \mathrm{~km}$ length, though variations over this great distance are also notable.

\section{Stratigraphic Context}

In the type region, the Ione is generally the lowest exposed Tertiary unit of the Sierran Superjacent series of Lindgren and Turner (1894) (fig. 6). Pre-Ione Eocene beds are present (though not exposed, except in one or two places) in parts of the basin (see, e.g., Pask and Turner, 1952; Chapman and Bishop, 1975). We are not aware of any Cretaceous sediments in the immediate type-Ione tract, although Upper Cretaceous (Chico) strata underlie the Ione and pre-Ione Eocene at the far-north end of the general Ione belt. West of the Carabas paleo-ridge (fig. 3), successively older pre-Ione strata onlap bedrock westward in the subsurface, as shown by borehole data. The pre-Ione Eocene beds are discussed more fully below. The Ione is generally overlain by the Valley Springs Formation of early Miocene age.

\section{Bedrock}

Except where pre-Ione Eocene or Upper Cretaceous strata intervene, the rocks below the Ione Formation belong to the "Bedrock series," separated from the Ione by "The Great Unconformity" (of Lindgren and Turner, 1894). A great variety of supracrustal rock units, mostly of Jurassic age and all metamorphosed to low grades, make up most of this bedrock complex. Late Mesozoic granitoid plutons also are present locally. There is some variability as to degree and depth of pre-Ione weathering. This tropical-tosubtropical weathering is an influence of prime importance in determining the character of the Ione sediments.

In many places, the Ione rests on deeply weathered but still readily recognizable bedrock. Locally, this bedrock has been thoroughly transformed into laterite, and the immediately overlying basal Ione may be reworked laterite. Hand lens examination of such ambiguous material, however, reveals sand grains among laterite clasts.

Most of the bedrock underlying, and adjacent to, the type Ione Formation belongs to the western belt of the Sierran foothills metamorphic belt; these prebatholithic rocks "can best be characterized as a series of elongate northwest-trending belts separated from one another by major, steeply dipping fault zones (Schweickert and Cowan, 1975). The nearest of these major fault zones is the Bear Mountains fault zone, roughly 4-9 km (2.5$5.5 \mathrm{mi}$ ) east of the east edge of the Ione outcrops (fig. 2). The fault zone is marked by a narrow and fairly persistent belt of serpentinite. At this latitude, the fault zone separates the western belt from tectonic melange on the east. Bartow (1979) found that the Melones fault zone, parallel to and east of the Bear Mountain zone, shows some postMehrten movement. 
Two general kinds of rock, both Upper Jurassic, and together characterized as an island arc sequence, constitute the local bedrock. These are (1) "greenstone" metavolcanicslow-grade metamorphosed (greenschist facies) mafic to felsic rocks, mostly pyroclastic, but including some flows (partly pillow lavas); and (2) metasedimentary rocks - mostly dark gray to black slate (and some phyllite), with local interbedded lenses of metasandstone (graywacke) and conglomerate.

The greenstone has been mapped as Logtown Ridge Formation, while the slate was assigned to the Mariposa Formation (Pask and Turner, 1952; Chapman and Bishop, 1975). However, Clark (1964) proposed a revision of the stratigraphic relationships and nomenclature pertaining to these rocks. In, and only in, the western belt, greenstones formerly assigned to the Logtown Ridge Formation are now designated Gopher Ridge Volcanics; the metasedimentary rocks of the Mariposa Formation are named Salt Springs Slate. No age changes were indicated, and of course the rock types themselves remain unchanged. The Gopher Ridge Volcanics underlie and in part intertongue with the Salt Springs Slate. The latter carries late Oxfordian to early Kimmeridgian fossils. The metasedimentary rocks generally are less resistant to erosion than are the metavolcanics and "commonly underlie gentle valleys between ridges of the more resistant greenstone" (Chapman and Bishop, 1975). For example, the Carabas paleo-ridge, along the western edge of the type Ione region, is developed on greenstone.

\section{Pre-Ione Eocene Rocks}

Within the type Ione region, wherever the base of the formation crops out, it is seen to rest on bedrock. However, in some deep boreholes, there are intervening strata which probably are Eocene, but which differ significantly from the Ione. These rocks, in part because they are subsurface, have remained unnamed. Bateman and Wahrhaftig (1966) presented a useful summary of these pre-Ione deposits, both within the type Ione region and, more generally, along the belt as a whole.

In Jackson Valley, pre-Ione beds (Eocene?) are encountered in several boreholes (Pask and Turner,1952). The rocks are green, gray, and greenish white sands and clays; conglomerate amounts to less than 10 percent. Biotite is a prominent constituent, along with chlorite; quartz content is high, but feldspar approaches or exceeds 25 percent. Locally, the section is highly carbonaceous. The maximum thickness is about $39 \mathrm{~m} \mathrm{(130}$ feet), but it decreases rapidly toward the basin margins. And, as stated above, these beds do not reach the present outcrop.

Also in the type area, pre-Ione Eocene (?) rocks were encountered in two core holes near Carbondale (Chapman and Bishop, 1975). These rocks "appear not to have been subjected to the high degree of weathering associated with the Ione". They consist of gray sandstone and greenish clay, with minor conglomerate. Thicknesses encountered were about 18 and 24 meters (58 and 78 feet, respectively). Details of mineralogy are not reported, but the lithology is said to be closely similar to that described by Pask and Turner (1952) in Jackson Valley.

The distribution of basinal pre-Ione deposits in the subsurface suggests that the integrated paleochannel system on bedrock delineated by Chapman and Bishop (1975; our fig. 7 ) was excavated in pre-Ione time. Those portions of it below modern sea level 
are characteristically filled in part by pre-Ione deposits. This pre-Ione channel system is the precursor of the basin in which the type Ione Formation accumulated.

Not all of the pre-Ione Eocene strata are fine-grained basinal facies. Along the former extrabasinal fluvial channel now followed by highway 16 and Arkansas Creek,

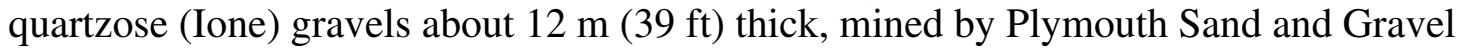
(fig. 8), are underlain by several meters of a more labile, carbonate-cemented cobble gravel that seems to form part of the fill of the same channel system. The angular clasts include quartz, chert, greenstone volcanics, slate, etc., and the sandy matrix contains feldspar and epidote. Pyrite forms part of the calcareous cement. Plant fragments have apparently been replaced by siderite. Gold is recovered from both this gravel and the overlying Ione gravel (Greg Huyser, Plymouth Sand and Gravel, oral commun., 1995). This lower unit expands our perception of pre-Ione deposits into the proximal fluvial environment.

Pre-Ione Eocene strata are known in a few areas beyond the type region. Such rocks were described from several boreholes in the northeastern San Joaquin Valley by Piper and others (1939). In one deep hole near Lockford, 24 kilometers (15 miles) southwest of Ione, the last 200 feet penetrated were dark gray and brown shale and brown sand, with carbonaceous streaks. Megafossils recovered were identified as marine, and included a form of Exilia said to be characteristic of the Meganos stage (currently regarded as lower Eocene).

North of the type Ione region, pre-Ione Eocene beds crop out in several areas, and have been given formation names. These include:

(1) at Lincoln, the Walkup clay, no thickness stated (Allen, 1929).

(2) at Sutter (Marysville) Buttes , the Dry Creek Sandstone Member has been included in the Ione as its lowest 15 meters (50 feet) (Stewart, 1949; see also Dickerson 1913, 1914, 1916; Williams, 1929; Allen, 1929; Johnson, 1943).

(3) at Oroville Table Mountain, the Dry Creek Formation, up to 24 meters (80 feet) thick (Dickerson 1913, 1914, 1916; Allen, 1929; Creely, 1965).

The marked variations of thickness seen in the pre-Ione Eocene rocks undoubtedly reflect irregularities of bedrock topography. The presence of these strata allowed the Ione itself to be more uniform in thickness. On another scale, the pre-Ione rocks must wedge out toward the east. Conversely, west of the study area these strata eventually "work free" of the constraints of the bedrock, as it were, and assume something like normal (i.e. regional) thicknesses and take their place as a conventional part of the Great Valley Late Mesozoic-Cenozoic stratigraphic pile. We believe that these pre-Ione Eocene rocks most likely correlate with the lower Eocene Capay Shale of the Northern Coast Ranges and subsurface Sacramento Valley. Generally, the Capay is regarded as a relatively deepwater deposit. In most cases, the pre-Ione rocks represent a shallow-water phase. But except for the Arkansas Creek occurrence, they are marine.

Biotite is present, along with chlorite and muscovite, in the pre-Ione Eocene rocks. Feldspar constitutes 20 to 30 percent of the grains, and other aspects of the mineral assemblages are similarly labile locally. Glauconite has not been reported here, although it is present in pre-Ione Eocene beds elsewhere. Clays are kaolinitic and share some characteristics with the upper Ione member. Granular kaolinite ("anauxite") is sparse to absent. 


\section{Ione Formation}

The Ione is commonly differentiated from adjacent units by its mineralogy, so this will be summarized here. The most characteristic mineral throughout the Ione is the pearlylustered granular kaolinite, up to very coarse sand size, known as "anauxite" (in literature described below). Quartz is abundant, in some sections to the near exclusion of other framework minerals. Feldspar content varies considerably, although not as simply as previous literature might suggest. Heavy mineral suites are characterized by the stable minerals ilmenite, zircon, andalusite, and rutile. Thus beds that are quartzose, anauxitic or otherwise kaolinitic, and with mature heavy mineral suites are likely to be Ione; the presence of as much as 20 percent fresh or altered feldspar, however, is to be expected. Pask and Turner (1952) divided the Ione of the Buena Vista area into two members, designated simply as lower Ione and upper Ione. These were based in part on detrital mineralogy. Feldspar grains are reported to constitute as much as 8-10 percent of grains in the lower member, but as much as 20-25 percent in the upper Ione. Biotite and chlorite are unusual in the lower member, whereas they are consistently present in the upper unit. The clays in both members are kaolinitic, but exhibit different DTA (differential thermal analysis) signatures (Pask and Turner, 1952). The lower Ione reportedly has a heavy-mineral suite dominated by the more stable minerals, such as zircon and ilmenite, while the upper member contains less resistant species like hornblende and epidote. A more detailed discussion of the petrography of the Ione sands is included in a later section.

\section{Valley Springs Formation}

In complete sections (fig. 6), the Ione is overlain by the Valley Springs Formation (Gale, in Piper and others, 1939) of early Miocene age. It consists mostly of relatively finegrained sedimentary and/or pyroclastic rock. Rhyolitic detritus is generally present, and in some instances is dominant. The most characteristic rock low in the section is hard claystone with numerous sub-vertical fractures (probably the "clay rock" of the early folios). It is typically light-colored, ranging from white to light gray or light tan, generally with a faint but distinct greenish cast. A few beds of conglomerate also are found. A distinctive basal conglomerate is present locally. For exmple, one near Lancha Plana (site) contains cobbles of hard, fresh rhyolite; clasts of fresh andesite are lacking.

The level at which to draw the contact between the Ione and Valley Springs units can be problematic (see, e.g., Gillam, 1974). In some places, however, where the lowest part of the Valley Springs contains the distinctive basal conglomerate described above, the contact is readily apparent. The contact between the Ione and the overlying Valley Springs Formation is a strong erosional unconformity. Accordingly, basal beds of the Valley Springs in different areas rest on different stratigraphic levels of the Ione, indicating that the Ione was differentially and deeply eroded prior to deposition of the Valley Springs. The most compelling evidence is seen in the contrast of the stratigraphic relations across Jackson Valley. In the south, the Ione section capped by the Valley Springs is complete, i.e. it includes both the upper and lower members of the Ione. But north of Jackson Valley, the Valley Springs rests directly on the lower Ione; the upper Ione was stripped prior to Valley 
Springs time. Once it was deposited, the Valley Springs played an important role in protecting the generally softer Ione from further weathering and erosion.

The Valley Springs contains rhyolitic glass (shards and pumice fragments), along with phenocrysts (euhedra) of quartz, sanidine, plagioclase, and biotite. At least some of the clays are smectitic. Anauxite is sporadically present in the lower beds, which we attribute to reworking of the underlying Ione.

\section{Strike-Belt Context}

Over the total outcrop belt length of $320 \mathrm{~km}$ (200 miles), the type region appropriately lies in the middle, and this core area is the largest of all the discontinuous exposures (Fig.1). The type region is defined as a more or less continuous outcrop area from the latitude of the Cosumnes River, on the north, to that of Valley Springs on the south (figs. 2-4). The bulk of this area lies in Amador County, with small parts in Sacramento County and Calaveras County. Thus defined, the type region is about $50 \mathrm{~km}$ (30 miles) parallel to strike and $7 \mathrm{~km}$ ( 4 or 5 miles) across the belt.

Generally, along the belt as a whole, since the formation dips mostly to the west, the east margin marks the base of the formation, while that on the west side represents the cover of younger rocks. West of the latter contact, the Ione occurs in the subsurface for a considerable distance (see section on Age and Correlation). One significant exception is in part of the type region itself, where the Ione onlaps the exposed bedrock of the Carabas paleo-ridge (figs. 2-5).

Outcrops beyond the core area are much more discontinuous (Fig.1), mostly because younger Tertiary units with slightly lower dips lap onto bedrock and conceal the Ione. The largest gap lies between Valley Springs, at the south end of the type region, and the small outcrop area centered on Knights Ferry, some $35 \mathrm{~km}$ ( 22 miles) to the south. The Valley Springs-Knights Ferry gap is directly in line with a northeastward extension of the Stockton arch, an elongate positive area during early Tertiary time. We infer that the Ione was deposited in this area and later subjected to differential uplift and erosion, because both the Valley Springs and Knights Ferry sections are fairly complete.

The study area, the type region of the Ione Formation, is unusual in the Ione outcrop belt in forming a sizeable discrete area of Ione Formation. This in turn may be a result of another unusual factor--the presence of a half-buried ridge of greenstone bedrock $22 \mathrm{~km}$ west of the main basin-foothills contact that extends NNW-SSE almost the length of the study area (including subsurface extensions; Chapman and Bishop, 1975), the Carabas paleo-ridge of this report (figs. 3,4,8). Given the generally westward dip of the Ione Formation, parts of this paleo-ridge must have stood high above the surface of Ione Formation accumulation, and together with bedrock of the Sierra foothills, must have delimited a discrete basin at the eastern margin of the larger Great Valley basin. As we shall see, it is the eastern rather than the western margin of this sub-basin that is problematic.

\section{Sierra Context}

The Ione Formation was deposited prior to the tilting that formed the modern Sierra Nevada, which began about $5 \mathrm{Ma}$ (Bateman and Wahrhaftig, 1966; Grant and McCleary, 
1977). The relief of the ancestral Sierra coeval with the Ione Formation is largely unknown, but discussed below.

Many authors have noted the mineralogic similarity of the Ione Formation to the Eocene auriferous gravels of the Sierra Nevada foothills, and have therefore proposed broad correlation. Some have mentioned interfingering relations (Lindgren, 1911; Allen, 1929). We find the relation even stronger than previously supposed; erosional remnants of Ione basinal facies extend into the area of auriferous gravels and include gritty to gravelly horizons formerly mined for gold. Therefore, some auriferous gravels of the Sierra foothills represent the fluvial feeder system of the Ione basin but others may be Ione basinal deposits with finer facies eroded away. Such relations are described below.

\section{Paleoclimate Context}

Eocene climates were generally marked by tropical or subtropical conditions of elevated temperatures and high rainfall. Vegetation was correspondingly dense. In the Sierra Nevada these influences combined with low relief to produce deep chemical decay. Paleosols were kaolin-rich and otherwise consisted of only the most stable minerals such as quartz. Ferruginous laterite was produced along the east flank of the greenstone paleoridge. Locally, to the east, slate bedrock was converted to more-or-less pure kaolinitic clay. In this case some coincindental influence of prior hydrothermal alteration (associated with mineralization along the Foothills copper belt) has been suggested. These supermature assemblages provided a very specialized and distinctive provenance for the Ione sediments. It is possible that local upward-increasing feldspar contents in the Ione reflect progressive stripping of deep soils in source areas.

Weathering of the Ione Formation itself is probably a product not only of Eocene paleoclimate but also of a later extended period before it was buried. The age of overlying Valley Spring Formation is thought to be about 20-23 Ma, whereas that of the Ione Formation seems likely to be more like $49 \mathrm{Ma}$. Evidence of in situ weathering includes sawtooth terminations of prismatic minerals like hornblende.

\section{Economic Context}

The Ione Formation is an intriguing target for economic geologists; virtually every rock type in it has current or potential value (see fig. 8 for exploitation sites). Its sands are mined for silica and other uses, and contain valuable heavy minerals. Its clays tend to be refractory and are used for firebrick and other ceramic products. Perhaps the most common rock type, clayey sand, is used in cement manufacture. Lignites of the Ione Formation are used for wax manufacture and power generation. Lateritic clays at the base of the formation are used as aluminous additives to cement and locally contain aluminum hydroxides. Thus the formation is one of California's most important industrial-mineral assets (Carlson and Clark, 1954; California Division of Mines, 1956). In addition, some gravels in the Ione Formation were formerly mined for gold, and correlate with the rich Tertiary gold placers of the adjacent Mother Lode area.

The economic value of so many Ione lithotypes partly derives from a scarcity of supermature mineral assemblages in western U.S. locales. That so much activty in the Ione is concentrated in the type area is due in addition to the low degree of induration of 
many lithotypes there, in marked contrast especially to Ione Formation south of the Stockton Arch, which is generally highly indurated.

Study of the Ione Formation by the second author was prompted by a need to investigate the heavy-mineral potential, said by Gomes and others (1979, repeated by Force and Lynd, 1984) to be considerable, and by a desire to understand the relation between gold and heavy mineral enrichment (Force, 1991). Some results are published separately by Force and Creely (2000).

\section{New Work}

\section{Structure}

The Ione Formation is in general structurally simple. In most of the study area it dips WSW about 1.5 degrees, based on correlation of beds rather than individual outcrops, where dips commonly vary by as much as 5 degrees. To the west, the Ione goes into the subsurface of the Great Valley.

The Carabas paleo-ridge (figs. 3, 8), composed of metavolcanic bedrock, forms the western margin of the basin containing the type area of the Ione. Adjacent to this feature, reversed (east) dips are as much as 7 degrees (Bates, 1945; Pask and Turner, 1952), i.e. the sequence is draped over the ridge due in part to differential compaction in the clay-rich sequence. Thus at least part of the Ione basin has the aspect of a shallow syncline (fig. 5). This syncline is readily seen, for example, in cross-sections based on drilling in the Jackson Valley (Pask and Turner, 1952).

The paleoridge as a physiographic feature is limited to the west-central part of the study area. However, the greenstone that forms the paleoridge crops out sufficiently far downstream in both the Cosumnes and Mokelumne riverbeds that we suspect its presence as a positive feature in the subsurface for the intervening distance, a conclusion supported by the geophysics of Chapman and Bishop (1975). Thus the importance of this paleoridge in determining synclinal structure, basin geometry, and depositional facies is considerable.

Depositional relief was appreciable along both basin margins, so that buttress unconformities of Ione Formation on bedrock are common. However, we think that the eastern basin margin is complicated by down-to-west faults in two segments (fig. 4):

1) In the Jackson Creek area (fig. 8), a west-facing nearly-straight escarpment typically 200 feet high separates bedrock from Ione Formation, except in valley bottoms where bedrock extends west of the escarpment. A near-vertical fault along this trend was noted by U.S. Army Corps of Engineers (1995) in the bedrock spillway for Lake Amador and in a nearby trench; it cuts some post-Ione deposits. The nearest Ione Formation is finegrained and dips eastward into the fault, making an unconformable relation unlikely. Down-to-west throw is probably no greater than 330 feet $(101 \mathrm{~m})$, based on correlation of the sub-Ione unconformity from Jackson Creek to Waters Peak, and on gravity profiles in Chapman and Bishop (1975). This fault could form the basin margin for three miles or more.

2) In the Willow Creek area (fig. 8), fine-grained Ione Formation about 150 feet thick (Chapman and Bishop, 1975, seismic section b-b' coupled with adjacent exposures) is 
juxtaposed against bedrock along a straight contact (not as shown by Bartow and Marchand, 1979). This fault was never observed directly, but it could form the basin margin for more than a mile.

The faults correspond to the straight segments of the Ione-bedrock contact as seen in plan. Bedding and structure contours in the Ione Formation form sags adjacent to these faults (fig. 9). In contrast, the apparently unfaulted eastern margins are digitate due to low-angle onlap of Ione outliers onto basin shoulders. Disconnected outliers continue to the northeast from the unfaulted segments, but are absent opposite the faulted segments, implying preferential uplift and erosion adjacent to the faulted segments.

The age of the basin-margin faults is uncertain, but the common presence of fine-grained facies and the lack of unusually coarse-grained conglomerates adjacent to these faults suggests they are post-Ione rather than syn-Ione. The clasts in the conglomerates just west of the faults are largely or exclusively milky quartz, not coarse fragments of recognizable local bedrock. However, the base of the Ione is locally offset more than horizons high within it, consistent with faulting coeval with upper Ione strata. This coupled with the apparent continuity in gradient of the late Miocene Mehrten Formation across the study area suggests the faults are post-mid Eocene but pre-late Miocene. Evidence relative to the Valley Springs Formation is unclear. These faults play an important part in the interpretation of paleogeography, as outlined in a later section.

Bartow and Marchand (1979) show several short (1.5 to $2.5 \mathrm{~km}$ long) high-angle (normal?) faults in the hills south and southwest of Buena Vista. Two of these in postIone rocks are closely spaced and form what appears to be a horst; another juxtaposes Ione and Valley Springs Formations. Elsewhere, faults in Ione rocks of a few meters displacement can be seen in several roadcuts (fig. 10), and no doubt others could be found if exposures were better. But internally, faulting in the Ione Formation appears not to be a major factor in lithologic distribution.

Other deformational structures in the Ione Formation of the study area include a small tight upright anticline (fig. 11). This isolated structure may have formed as a mud diapir.

\section{Depositional Setting: Description and Distribution of Facies}

One emphasis of our study is that of geographic and temporal variation of environments (environmental complexity). A major part of the Ione Formation represents deposition under nonmarine, especially fluvial, conditions. Lesser parts are marine and estuarine. These facies interfinger, and progradational parts of the sequence can be considered deltaic complexes.

\section{Nonmarine Facies}

A significant part of the Ione Formation in its type region appears to have been deposited under nonmarine conditions (Gillam, 1974; Rodgers, 1986; Wood and others 1995). A variety of subenvironments can be recognized. Much of the formation is fluvial, with lesser portions representing lacustrine and paludal deposition. Most of the sediments were derived ultimately from an eastern source, the remnants of an ancestral Sierra Nevada. This system has been viewed as a westward-prograding deltaic complex 
(Allen, 1929; Gillam, 1974), but we find that southward axial feed was important, especially from sources in the Muletown-Irish Hill area (fig. 8). Basin fill north of this area seems to be entirely non-marine and represents a separate dispersal system, mostly of pea-gravel conglomerates.

The basal deposits along the eastern margin of the basin, are gravels and coarse sands laid down on alluvial fans or aprons (Rodgers, 1986). Thick conglomerates as coarse as -6 to -8 phi are present (fig. 12), interbedded with sands, and overlain by sands and clays. These locally pass up-gradient (across basinal contacts) into extrabasinal deposits of the same kind, and seem to tie in to aurifierous gravel, i.e. proximal Ione, channels preserved in the higher parts of the range to the east.

Trends in maximum clast sizes in these conglomerates show westward-fining with local reversals where dips bring new horizons to the surface, but size trends show little relation to the contact of basinal deposits with bedrock (fig. 12). That is, non-marine basinal Ione conglomerates pass continuously into and are inseparable from extrabasinal "auriferous gravels." Clast-size trends crossing the basin margin along large Eocene drainages (profiles 1 and 4) may have more gradual gradients than those along lesser drainages.

At least three major feeders which furnished sediments to the type Ione can be identified as described below. They are marked by discrete and significant concentrations of gravel or conglomerate along the eastern basin margin. Clay-dominated sections such as that at the Gladding McBean pit north of the study area near Lincoln (fig. 1) probably represent former interfluves.

Succeeding finer-grained deposits spread westward and southward as extensive, wellbedded sheets of gravelly sand. Both braided- and meandering-stream deposits appear to be present. In the northern part of the area large volumes of clay were laid down as overbank deposits and clay plugs in abandoned channels.

In the Buena Vista area (fig. 8), Gillam (1974) interpreted an upward succession of facies from lagoonal at the base of the formation through interbedded meandering and braided fluvial deposits and a lacustrine interval, into shallow-marine deposits. Farther north, in the central part of the basin, Wood and others (1995) found structures indicative of a complex of anastomosing streams. They cite low-sinuousity channels $2+\mathrm{m}$ deep associated with thin-bedded braided fluvial deposits, mostly clayey sands. In their view, the cohesiveness of these sands may have favored the anastomosing nature of drainage. In the northern part of the basin, Wood and others noted thick and extensive clays formed as overbank deposits.

Interchannel areas accumulated light- to medium-brown ("chocolate" in some literature) shales, probably representing swampy to lacustrine conditions. Some silts and clays accumulated under a state of low oxygen such that some organic carbon was preserved. Extensive, heavily vegetated swamps formed early in Ione time ultimately led to the formation of valuable low-sulfur lignite beds (fig. 13; see also Stout in Wood and others, 1995). 


\section{Marine and Transitional-Marine Facies}

A basic observation of this study is that marine and estuarine facies, mostly sands, are widely distributed in the Ione Formation of the study area. Since this topic has been much mentioned, and to some extent debated, in previous work (see, e.g., Allen, 1929; Gillam, 1974; Palmer and Merrill, 1982; Merrill, 1984; Rodgers, 1986; Glasmann and Wood, 1995), we will focus on the evidence before proceeding. The presence and distribution of marine facies is based on several lines of evidence, falling into the categories of paleontology, mineralogy, sedimentology, and paleogeography.

Paleontologic evidence consists of both body fossils and trace fossils, and is discussed more fully in a later section. Marine molluscan assemblages have been found at two localities in the study area. Far more abundant are trace fossils of probable marine or estuarine origin; these are primarily Ophiomorpha and cf. Thalassinoides.

Mineralogic evidence of marine origin includes occurrences of glauconite and gypsum. Glauconite is abundant in a thin, hard sandstone cropping out west of the Gage pit (fig. 8). Numerous rosettes of gypsum (selenite) can be found weathering out of the clay in several localities, including the south part of the Bacon pit. These occurrences suggest open-marine and coastal evaporitic environments, respectively.

The sedimentologic evidence consists primarily of homogeneous, frameworksupported, moderately sorted sands in units typically 3-10 m thick. These are without interbedded gravel or clay, and generally are in large-scale, low-angle cross-sets. In some cases, low-angle cross bedding is marked by heavy-mineral laminae, suggesting a beach (foreshore) environment (figs. 14, 15). Locally, sands may be in high-angle sets (usually containing Ophiomorpha), associated with more finely interbedded but bioturbated sandclay alternations, some with rip-up horizons and some with herringbone cross-laminae. In one locality such beds contain gravel with bored clasts. We ascribe such sequences primarily to intertidal-flat and tidal-channel environments. For those localities that lack trace fossils, show high-angle cross-sets, and/or contain gypsum, we suggest associated supratidal-eolian environments, though some may be subtidal and others may be unfossiliferous intertidal deposits.

Paleogeographic evidence relates to the three-dimensional configuration of the facies thought to be marine. The base of this facies conforms to a closed depression in the central part of the Ione basin, as shown by drilling carried out by Owens-Illinois and reported by Gillam (1974). Her depiction (fig. 16) is robust, as this depression is closed both in current configuration and after correction for dip, and suggests the lack of an integrated fluvial system, at least in this basal, apparently marine horizon.

Applying these several criteria, we find that marine facies occur in at least two horizons, apparently forming transgressive-regressive wedges (fig. 17). These lie within the upper and lower halves, respectively, of the Ione Formation. The present distribution of these facies is presented in figure 18, based on stratigraphic sections like those of figure 19.

Because of the way that erosion has differentially affected these horizons, we have a more complete picture of the lower marine facies than of the upper. The original extent of the lower facies is not constrained except to the north, where marine deposits pinch out into fluvial deposits, and eventually (north of Ione) pass into a whole different sediment-distribution system. To the west, the lower marine deposits must onlap the 
Carabas paleo-ridge. Our knowledge of the situation to the south is limited; the measured section at Lancha Plana (fig. 19A) is of a reconnaissance nature, but may include both the lower and upper marine facies. The extent of marine deposits, or indeed any basinal deposits, to the east is confused in detail by faulting, described above. There is an indication of a pinchout of marine facies against the current eastern margin of the main outcrop belt on Mesozoic bedrock in only one locality, the Newman pit (fig. 19B). Indeed, much of the body-fossil and mineralogic evidence for a marine origin of the sand units comes from sequences located against this margin or in outliers slightly east of it (fig. 18).

Several of the more recognizable subdivisions of the type Ione discussed below coincide with marine facies. The "Ione sand" of Pask and Turner (1952; in this paper considered the Ione Sand member of the Ione Formation) constitutes part of the lower marine wedge. Similarly, the "hard white sandstone" (and its fossiliferous red variant) is an integral part of the upper marine horizon.

A significant portion of the Ione section exhibits features indicative of tidal influences. Several of the sand bodies can be interpreted as intertidal sand flats; features exhibited include herringbone and flaser bidirectional ripple sets, intertidal burrows (Ophiomorpha, Thalassinoides), reactiviation surfaces, clay drapes, sigmoidal cross bedding, and rip-ups (fig. 20). Sequences are commonly fining upward.

We have no evidence of tidal range, but note that if the basin was closed on the north, the geometry and size of the basin may have been such that tidal resonance produced high tides, consistent with the extent of intertidal facies.

Descriptions of Ione lignites (Stout in Wood and others, 1995) that emphasize their lowsulfur character (and hence non-marine origin), but these descriptions ignore the common presence of pyrite and/or gypsum in other, non-economic lignite occurrences located elsewhere. We suspect, but are unable to prove, that maps of Ione coal basins (fig. 3; Carlson and Clark, 1954) are outlining the non-marine parts of organic accumulations, and that some more sulfur-rich deposits represent coastal marshes.

Given the presence of both marine and non-marine deposits, the ubiquity of transitional facies, and the physiographic position of the Ione basin between flanking bedrock highlands, with entirely fluvial deposition at one end, it seems appropriate to describe the overall depositional setting as estuarine, with a possible fan-deltaic component as discussed in the next section.

\section{Deltaic-Complex Evaluation}

Several previous workers have characterized the Ione Formation as a deltaic complex (Allen, 1929; Gillam, 1974). This is an appealing idea, and one to which we subscribe, with reservations.

The Ione can be logically viewed as a deltaic complex in a broad sense, containing a fluvial sequence in a paleo-shoreline situation. This said, there is little evidence of some classic features of the standard deltaic model (such as delta shape, prodelta beds, etc.). One reason for this may be that the type Ione was deposited in a markedly narrow basin, i.e. there simply was no room for the growth of the typical delta shape. Rather, the Ione may represent a case of forced deposition, with the greenstone 
Carabas paleo-ridge acting like a gigantic shore-parallel groin. The presence of finegrained marine facies against the eastern margin of the Ione basin permits a slight development of typical delta shape on that margin, however.

Prodelta clays have not been recognized; but the Ione Sand member may be a delta-front sheet sand. Locally in the Ione, there are a probable mud diapir (Fig. 8) and contortional bedding, features frequently associated with deltas.

The regressive upper limbs of each transgressive-regressive wedge as described above (fig. 17) are the best candidates for truly deltaic deposition. Since coeval basinal deposits to the north of each regressive sequence include conglomerates, the term fandelta might be appropriate. At times of transgression, estuarine deposition probably would be a better description.

\section{Paleontological Evidence for Marine/Estuarine Deposition}

Except for trace fossils and occasional plant remains, fossils are nearly nonexistent in the Ione Formation. Body fossils, in the form of marine mollusks, have been found so far at only two widely separated stratal levels in the type Ione. The beds at those two horizons, however limited, are unquestionably marine. Trace fossils, in contrast, are abundant; discrete burrows of at least two varieties are widespread. We believe that these most likely formed under marine or estuarine conditions.

\section{Body Fossils}

Casts of marine mollusks have been found at two stratally separate localities. The pronounced paucity of fossils, other than trace fossils, in the Ione may be explainable as a function of deep chemical decay, which affected not only the source area prior to erosion, but which may have been prolonged into the post-depositional period as well. This could have led to the near-total destruction of such body fossils as may have been preserved up to that point.

The most prolific (though small) assemblage is in the stratigraphically highest portion of the Ione, just south of Camanche Parkway North (fig. 8). This locality was first noted by Turner (1894). The fauna was identified by Dickerson (1916) and includes seven genera (with three firm, and one tentative, species). Based on modern West Coast and Hawaiian analogs, three genera indicate marine waters ranging from "shallow" $(<30$ ft. or $9 \mathrm{~m}$ ) to "moderately deep" ( $80 \mathrm{ft}$. or $24 \mathrm{~m}$ to $200 \mathrm{ft}$. or $61 \mathrm{~m}$ )(Morris, 1966).

A new locality, discovered in this study, is in a shallow excavation just east of calcining plant no. 2 (fig. 8). There, a thin bed of light brown claystone in the lower Ione contains scattered casts of small bivalves. Two forms were identified by Charles Powell, U.S. Geological Survey, and, independently, Richard Squires, California State

University, Northridge. Both gentlemen agree that one form is almost certainly Nuculana (formerly Leda) (fig. 22). A second, less abundant form is possibly Cuspidaria. Marine water depths for modern species of Nuculana are in a wide range of $30 \mathrm{ft}$. $(9 \mathrm{~m})$ to over $200 \mathrm{ft}$. (>61 m). Cuspidaria characteristically occurs in "moderately deep" waters (80 ft. to $200 \mathrm{ft}$. or $24 \mathrm{~m}$ to $61 \mathrm{~m}$; Morris, 1966). 


\section{Trace Fossils}

The trace-fossil burrows Ophiomorpha and Thalassinoides are common in widely distributed parts of the study area. Since they are a major factor in our assignment of a marginal-marine to estuarine origin for their host deposits, some description is in order.

Ophiomorpha forms mostly-vertical slightly-indurated tubes about $0.5-1.5 \mathrm{~cm}$ in diameter with nodular or mammillated exterior surfaces (figs. 23-25). These commonly branch at depth to include nearly-horizontal tubes. Thus they compare well with Ophiomorpha as described by Frey and others (1978). Burrow host deposits are most commonly sands, generally loose sand, but locally include mudstone (cf. Frey and others, 1978). Tube fillings range from clays to grit and commonly contrast with the burrow host, they frequently exhibit meniscoid structure. Tube walls are generally sandy clay, presumeably pelletal where mammillated, and commonly iron-oxide cemented.

Thalassinoides burrows, about the same diameter but smooth-walled, form networks mostly parallel to bedding (cf. Hill, 1981 ) with branching at obtuse angles (fig. 26). Locally these networks are dense, with much overprinting of older burrows by younger. Generally both the host deposit and the burrow fill are muddy, commonly with flaser bedding, but locally the host is clayey sand or grit. The burrow fill is generally muddy fine sand. Some burrows, i.e. non-mammillated vertical burrows in a muddy host, etc., are difficult to assign between Thalassinoides and Ophiomorpha (cf. Frey and others., 1978; Ekdale and othersl, 1984; Bromley, 1996).

Based on modern equivalants of these burrows, and fossil occurrences elsewhere, marine-to-brackish conditions seem indicated (Frey and others, 1978; Ekdale and others, 1984). The most common environments proposed for Ophiomorpha are beach faces down to lower foreshore, tidal channels and sandy tidal flats, sandy storm deposits, sandy estuaries and lagoons (Frey and others, 1978; Ekdale and others, 1984; Curran, 1985). Environments proposed for Thalassinoides include offshore sub-wavebase deposits, muddy lagoons, estuaries, and tidal flats (Ekdale and others, 1984). In many areas, the environmental difference between Ophiomorpha and Thalassinoides seems more a function of the amount of loose sand accumulating than of paleodepth, per se (Ekdale and others, 1984; Bromley, 1996). In our study area, relations between overlying Ophiomorpha-bearing and underlying Thalassinoides-bearing deposits looks transgressive in some sequences (figs. 28, 29), so we are inclined to think that the two trace fossils generally record more beach-like and more lagoonal deposits, respectively.

Merrill (1984) recorded Ophiomorpha in the Ione Formation at the south end of the Ione belt but proposed a non-marine origin. Since Merrill's observation was along an unconformity, it is worth noting that marine burrows commonly do not represent exactly the same environment as the sediment in which they are found. Very few authors have proposed non-marine origins for Ophiomorpha (Ekdale and others, 1984, Chamberlain, 1975).

The importance of Ophiomorpha in the Ione Formation may extend beyond interpretation of depositional environments. Pryor (1975) noted that the modern equivalent of this burrower enriches kaolinite at the expense of mixed clays. Thus Ione intertidal flats may have functioned as kaolinite factories.

Besides Ophiomorpha and Thassinoides, nondescript forms recorded simply as "bioturbation" are abundant at various horizons in the Ione (fig. 27). No particular study 
of these was made, other than to note their presence, and no conclusions as to environmental significance were drawn.

\section{Mineralogy-Petrology}

Considering the rather uniform appearance of Ione deposits in outcrop, Ione sands differ remarkably within the study area in both primary and diagenetic character. Besides grain-size differences, Ione sands range from quartzose to arkosic, from framework- to matrix-supported, from those with rounded grains to those that are extremely angular. Clay in the sands may occur as grains and chips, primary matrix, or secondary-diagenetic cement (fig. 30). Heavy-mineral content varies from less than $0.1 \%$ to more than $4 \%$, and heavy-mineral assemblages differ considerably. Table 1 describes the distribution of these variables with respect to location and stratigraphic position in the study area.

Other petrographic aspects remain remarkably constant (Table 1), especially in contrast to other Tertiary formations of the area. Angular quartz is the predominant framework constituent (fig. 30), commonly accompanied by chert or metachert. Potassium feldspar dominates where feldspar is present. Detrital mica flakes are common. Clay chips and crystalline clay grains (see below) are widely distributed framework constituents; these are everywhere kaolinitic as documented by Wood and others (1995) and other authors. Volcanic components are nowhere in evidence in the type area of the Ione.

We find that feldspar concentrations are not regular in either a stratigraphic or areal sense (Table 1). Feldspar content varies considerably even in individual lithosomes, notably the "hard white sandstone" of the Lancha Plana area (figs. 8, 19A). The stratigraphic control of feldspar content noted in the Buena Vista area by Pask and Turner (1952) is apparently only a local phenomenon. In some specimens, replacement of feldspar by clay minerals is apparent, and this process clearly could lead to feldspar distributions that are not stratigraphically controlled.

Heavy mineral assemblages of the Ione Formation in the study area are notable for their maturity (Table 1). Generally the order of abundance everywhere is ilmenite $>$ zircon $>$ tourmaline $=$ andalusite $>$ rutile (cf. Allen, 1929; Morris, 1962). Chromite is ubiquitous, and far more abundant than the literature would imply. A little allanite, staurolite, and/or kyanite are common. Morris reports a little corundum and garnet; Allen records sillimanite. The presence of trace amounts of monazite was suggested by chemical analyses of Wollenberg and Dodge (1973); we observed monazite directly. Labile heavy minerals are absent except in feldspathic sands and toward the base of the section at the extremities of the study area. These include the section at Lancha Plana and the basal Ione along the Cosumnes River (fig. 8), where a few percent of epidote and magnetite are present. North and south of the study area, labile heavy minerals such as hornblende are far more common in the Ione, as noted by Creely $(1965,1997)$ and Merrill (1984), respectively. Even in the study area, labile prismatic minerals show sawtooth terminations, indicating in situ alteration.

Polished sections show that ilmenite is the predominant opaque mineral in the Ione of the study area, commonly as porous grains suggesting precursor intergrowths with hematite. Skeletal ilmenite suggestive of precursor magnetite-ilmenite trellis textures is less common. Secondary hematite-?anatase alteration is strong in some 
specimens. Morris (1962) found opaque minerals (+leucoxene) to constitute 65-75 percent of the heavy mineral assemblage (by number in sized fractions). The equivalent figure in Gomes and others (1979) is 78 percent; they also showed that ilmenite in Ione sand is altered partly to pseudorutile and locally contains 63.5 percent $\mathrm{TiO} 2$.

Two occurrences of authigenic minerals carry implications for depositional environments. These are glauconite in sandstones west of the Gage pit , and gypsum, occuring as rosettes of selenitic gypsum in clay of the Bacon pit (fig. 8). Glauconite occurs as rounded detrital grains, commonly with glauconite rimming other minerals (fig. 30B).

Kaolinitic single-crystal grains are common in sandstone of the Ione Formation. In hand specimen they form pearly grains with perfect cleavage, commonly deformed; in thin section they are clear-to-brown grains (fig. $30 \mathrm{~A}, \mathrm{D}$ ) consisting of deformed and, less commonly, vermicular single crystals (fig. 30 E-F). Generally they have been called "anauxite" as a field term for the coarsely crystalline clay (cf. Allen, 1929) with or without compositional information. The composition and crystallography of anauxite in Ione sandstones has been described by Allen (1928, 1929), Ross and Kerr (1930), Langston and Pask (1969), and Allen and others (1969). Keller (1982) concluded that anauxite is a mixture of kaolinite and amorphous silica. Some authors propose an in-situ authigenic origin for Ione anauxite (cf. Williams and others, 1982, fig. 12-2, our fig. $30 \mathrm{~F}$ ). Clearly authigenic clay is present in some samples, but this clay cement does not have the habit of anauxite (fig. 30C). Anauxite in the sands appears to us to have two main modes of occurrence, as clasts and as "porphyroblasts" in clay clasts. The first origin can be related to the second with minimal further transport. Evidence for the detrital nature of some anauxite includes: 1) Rounding of some anauxite grains (fig. 30D), 2) Hydrodynamic equivalence of anauxite grains with slightly finer quartz grains in well-sorted sandstones (fig. 30A), 3) Mixtures of anauxite grains of different colors in the same specimen, 4) Anauxite occurrence side-by-side with unaltered feldspar, muscovite, and biotite with no suggestion of replacement, and 5) Local rimming of anauxite by glauconite, in grains that are themselves detrital (fig. 30B). However, such occurrence in sandstone is no evidence against an authigenic origin in interbedded argillaceous beds; here anauxite may be vermiform in clay matrix (fig. 30E).

The clays of the Ione Formation are economically important and have been studied intensively through the years. Numerous accounts have been published (see especially Dietrich, 1928; Bates, 1945; Johnson and Ricker, 1948, Pask and Turner, 1952; Wood, 1994; Wood and others, 1995). We have nothing to add here except for the following items:

(1) Clays ("underclays") directly underlying significant lignite beds in at least two localities are densely packed with coarse (to $\sim 1 \mathrm{~mm}$ diam.), vermiform kaolinite crystals. These are almost certainly authigenic. They appear too fragile to have been transported. The gross appearance of the crystalline mass is distinctly that of a growth fabric (cf. fig. 30F). Note that we do not hold that all the kaolin itself is authigenic, only that the texture has arisen as a post-depositional feature, i.e. it represents recrystallization.

(2) The clays of the Gage pit rest directly on bedrock, which here is intensely altered Jurassic slate. In fact, some of the clay is bedrock--- pure, white, kaolinitic clay, comparable in quality to the normal clays of the district. It has been suggested that 
the alteration is of a dual character---that the pre-Ione weathering (see "paleoclimate context")) was preceded here by local wall-rock alteration associated with mineralization of the Foothills copper belt (David Sanders, oral commun., 1996). A second special feature here is the conglomerate/breccia at the base of the Ione section. It is very coarse grained (clasts to $\sim 20 \mathrm{~cm}$ diam.) and matrix-supported. Both matrix and clasts are clay, both equally soft. One is tempted to suggest that the clasts, in their present condition, are too fragile to have been moved. By implication, at least some of the weathering must have postdated the accumulation.

\section{New Stratigraphic Framework}

The type Ione is relatively thin $(<195 \mathrm{~m})$; laterally, we have considered the type area to be about $50 \times 7 \mathrm{~km}$. But within these limited ranges, there is considerable complexity. The two-fold lithology-based subdivision proposed by Pask and Turner (1952), is apparently only valid in the local area they studied. For example, Chapman and Bishop (1975) were unable to recognize Pask and Turner's subdivision in a deep borehole (hole 1967-2) $3.8 \mathrm{~km}$ south of Buena Vista. Complexity is especially apparent when one examines distribution of feldspar content in sandstones. This seems to show no vertical or lateral regularity (Table 1).

Though we do not propose a formal subdivision, the transgressive-regressive wedges in the Ione provide excellent markers (figs. 17, 31). In addition, some of the commercial clays are sufficiently recognizable and widespread as to constitute mappable units. It is thus useful to adopt a two-fold geometric subdivision as a frame of reference.

The lower Ione can be informally defined as the part that includes the lower marine horizon and its non-marine envelope (figs. 17, 31). As such it includes the Ione sand of previous workers (Ione Sand member), and their Edwin and Cheney Hill clay units (cf. Bates, 1945). The upper Ione can be similarly defined as the upper marine horizon and its non-marine envelope. It includes horizons previous workers have called the "hard white sandstone" and the Chitwood clay.

Thus defined, the lower Ione is present thoughout the type region, but the upper Ione mostly is found only in, and south of, Jackson Valley. To the north, erosion has differentially removed most of the upper Ione member, although remnants may be preserved beneath the cover of Valley Springs Formation.

Figure 9 shows structure contours on the top of the lower marine horizon north of the Jackson Valley and on the top of the lower member of the formation as shown by Pask and Turner (1952) in and south of the Jackson Valley. The horizons seem to match up, and we therefore conclude that the top of the lower member (of previous usage) roughly corresponds to the top of the marine part of the lower transgressive-regressive wedge.

The persistent clay-sand unit in the lower Ione commonly referred to as the "Ione sand" (locally a mixture of clay and sand in roughly 50:50 proportion, Pask and Turner, 1952; the Ione Sand member of this report) is ironically both one of the important commercial clays and an important silica sand resource in the Ione. Outcrops are dazzlingly white, and at first glance, structureless. However, closer examination, especially at low sunangle, reveals mid-scale cross stratification, heavy-mineral laminae, and abundant burrows (Ophiomorpha?). 
Figures 4 and 32 show the general distribution of Ione Sand member and correlative untis in outcrop and subsurface over an area of about $50 \mathrm{~km}^{2}$. To the west it pinches out against the Carabas paleo-ridge. To the east it commonly laps against the bedrock contact, i.e. the unit originally extended eastward. Correlation of the unit south of North Camanche Parkway and north of Carbondale is unclear. Thickness of the unit is as much as $30 \mathrm{~m}$ in the areas of current silica mining (Gillam, 1974), but average thickness is probably about $10 \mathrm{~m}$, taking into account its partial erosion where it is exposed (fig. 33).

Heavy mineral content varies in Ione Sand member, locally reaching 4.3 percent, but averages about 1 percent in our samples. The heavy mineral assemblage is the same as in other parts of the formation throughout its type area.

Near the middle of the section, the "hard orange sandstone" crops out in several roadcuts along State Highway 88 (fig. 28, 29). It may be a variant of the Ione Sand member, the two representing different oxidation facies of the same lithosome that were positioned differently with respect to a paleo-water table.

An important commercial clay in the lower Ione is called the Cheney Hill. This is a distinctive brown or gray clay with abundant, widely dispersed matrix-supported coarse sand grains. Pask and Turner (1952) believed that their "Ione sand" and the Cheney Hill clay are approximate stratigraphic equivalents.

A separate upper transgressive-regressive wedge seems required south of the Jackson Valley due to the much greater thickness represented by marine facies there and the presence of new marine lithologic entities high in the section. A section at China Gulch (Camanche Parkway North) appears to have two marine (or estuarine) horizons with nonmarine beds between (figs. 31A, 34), whereas farther south a section at Lancha Plana (fig. 19A) could be marine or estuarine through the entire thickness above basal conglomeratic beds.

Various informal subdivisions in this upper wedge can be discerned in the local measured sections. For example, in the southern portion of the type area, the uppermost part of the Ione section is a singular, very resistant unit, the "hard white sandstone" (fig. 34), dipping gently west from as high as 900 feet elevation (fig. 35). It is up to $40 \mathrm{~m}$ (133 ft.) thick and is geomorphically important as a mesa former (figs. 36, 37).

\section{Dispersal Patterns-Auriferous Gravels}

Most, if not all, of the Ione accumulation was ultimately supplied from eastern sources (Lindgren,1911; Allen,1929; Bates, 1945), though within the basin axial transport was apparently common. At least three major feeders which furnished sediments to the type Ione can be identified; these include the previously identified "Tertiary Mokelumne" and "Tertiary Calaveras" rivers (figs. 38, 39). The feeders are marked by discrete and significant concentrations of gravel or conglomerate, especially toward the eastern side of the basin. The gravel bodies most likely represent alluvial fans or fan-deltas. Further evidence of multiple sources is seen in the variations, both stratal and lateral, in sandstone composition. For example, slightly less-mature (and presumably more proximal) heavy mineral assemblages are found at both the northern and southern ends of the basin. We believe that the overall source terrane was nonhomogenous and that the dominance of one drainage versus the other varied with time. 
Linkages to remnants of paleo-channels bearing auriferous gravels can be inferred in many cases. Auriferous gravels in this context is in the restricted sense, referring to the prevolcanic white quartz gravels of Lindgren (1911) and Bateman and Wahrhaftig (1966). Various authors have put forth the idea that the Ione Formation and these gravels are correlative (Lindgren,1894, 1911; Turner, 1894; Dickerson, 1916; Allen, 1929). In the simplest case, the gravels can be viewed as essentially a coarser, nearer-source variant of the Ione. Indeed, we use the term proximal Ione for extrabasinal gravels to emphasize this relationship.

\section{Relation of Faulting to Apparent Basin Geometry}

Faults occupy two segments of the eastern boundary of the Ione (fig. 4).The intervals of these faults correspond with the straight margins of the Ione basin without Ione (or auriferous gravel) outliers, and form sags in the structure contour map of key Ione horizons (fig 9). Other margins are characteristically digitate, due to low-angle onlap of the Ione on bedrock, and have outliers (e.g. fig. 37) predictable on the basis of structural level extending intermittently to the ENE as much as $12 \mathrm{mi}(19 \mathrm{~km})$. In two localities these ramps demonstrably involve parts of the lower Ione: Irish Hill where the lower marine sequence laps onto bedrock and Newman pit where the non-marine envelope of the lower marine sequence can be traced onto basin shoulders (fig.8).

Thus the basin-margin faults have colored our perception of the Ione Formation by "straightening" the apparent eastern basin margin and separating obvious basinal deposits from outlying equivalent auriferous gravels, including fine-grained deposits that might otherwise be regarded as basinal. Figures 9 and 31 show that marine-facies boundaries intersect the apparent basin margins in a way that suggests former marine deposition east of those boundaries. The outlying facies may include the true basin-margin deposits of a more equant original basin.

If this is the case, the absence of Ione on the east side may be explainable in terms of post-Ione uplift of the eastern block being accompanied and followed by erosion, largely removing basinal Ione deposits that once were present. The original Ione basin would have extended eastward, merging imperceptibly into its fluvial feeder system, and would have been far more equant than is currently apparent. Alternatively, some faulting may have been coeval with Ione deposition, and the eastern block never was an important site of deposition except in incised valleys that accumulated auriferous gravels. In either case, an Ione geomorphic surfaced extended far into the Sierra, with isolated highlands such as Valley Springs Peak above that surface.

The distribution of detrital gold and commercial clay in deposits of Ione age underscores this relation. Gold was mined in basinal parts of the Ione at Muletown and Irish Hill (Andrews, 1978). At Irish Hill coarse non-marine auriferous horizons both above and below the lower transgressive-regressive wedge (fig. 17, 31B, C) extend from the basin margin eastward onto bedrock. A discontinuous chain of outliers constitute the "auriferous gravels." Conversely, fine-grained deposits including commercial clays like those common in basinal Ione can be traced onto basin shoulders at both Irish Hill and the Newman pit (fig. 19B). Clays of unknown quality continue as interbeds in extrabasinal auriferous gravels. 


\section{Acknowledgments}

We are indebted to the many people who helped to further this project. Among these are the land owners who granted permission for us to enter their properties: Robert Boring, Richard Kreth, Roger Mehrten ( via Joe Mehrten), Charles Ruman, Stanley Van Vleck, and Frank Yager.

Companies or agencies cooperating in this way were East Bay Municipal Utilities District (Duke Foster, Superintendent of Recreation), Howard Properties (Larry Costick, and later Charlie Sager, General Manager), H.C. Muddox Co., (Larry Carnes, Division Manager), and Pacific Clay Products, Inc..

Company geologists or engineers cooperating included Mike Kizer (Ione Minerals and Refractories), James Hallsted (Owens-Illinois), and Greg Huyser (Plymouth Sand and Gravel).

Peter Brueggeman, Director of the Library at Scripps Institution of Oceanography, furnished a very useful list of references early in the study.

Chuck Powell, U.S. Geological Survey, and Richard Squires, California State University, Northridge, kindly identified fossils from a new locality.

Geologic consultant David Sanders was repeatedly willing to share his extensive knowledge of exploration and mining projects in the region.

Geologists who visited in the field and contributed valuable insights were Dave Andersen, Tridib Guha, and Ray Sullivan. The latter was especially helpful in interpreting estuarine deposits. Jane Force assisted the second author in the field.

We thank the reviewers of this paper, Brenda Houser and Andrew Grosz, and John Birmingham who improved the figures. The paper may never have seen the light of day without the logistic help of Jim Bliss.

\section{References Cited}

Allen, V.T., 1928, Anauxite from the Ione Formation of California: American Mineralogist, v. 13, p. 145-152.

Allen, V.T., 1929, The Ione Formation of California: Berkeley, University of California Department of Geological Sciences Bulletin, v. 18, p. 347-448.

Allen, V.T., Fahey, J.J., and Ross, M., 1969, Kaolinite and anauxite in the Ione Formation, California: American Mineralogist v. 54, p. 206-211.

Andrews, J.R., 1978, The ghost towns of Amador: Fresno, Calif., Valley Publishers, $137 \mathrm{p}$.

Bartow, J.A., 1979, Constraints on the latest movements on the Melones fault zone, Sierra Nevada foothills, California: U.S. Geological Survey Professional Paper 1126J, 4 p. [http://pubs.er.usgs.gov/usgspubs/pp/pp1126AJ ].

Bartow, J.A., 1991, The Cenozoic evolution of the San Joaquin valley, California: U.S. Geological Survey Professional Paper 1501, 40 p. [http://pubs.er.usgs.gov/usgspubs/pp/pp1501 ].

Bartow, J.A., and Marchand, D.E., 1979, Preliminary geologic map of Cenozoic deposits of the Sutter Creek quadrangle, California: U.S. Geological Survey Open-File Report 79-436 [http://pubs.er.usgs.gov/usgspubs/ofr/ofr79436 ]. 
Bateman, P.C., and Wahrhaftig, Clyde, 1966, Geology of the Sierra Nevada, in Bailey, E.H., ed., Geology of northern California: California Division of Mines and Geology Bulletin 190, p. 107-172.

Bates, T.F., 1945, Origin of the Edwin Clay, Ione, California: Geological Society of America Bulletin, v. 56, p. 1-36.

Bromley, R.G., 1996, Trace fossils--biology, taphonomy, and applications: London, Chapman and Hall, $361 \mathrm{p}$.

California Division of Mines, 1956, The mineral resources of the Ione Formation: Mineral Information Service, v. 9, no. 8, 5 p.

Carlson, D.W., and Clark, W.B., 1954, Mines and mineral resources of Amador County, California: California Journal of Mines and Geology, V. 50, p. 149-245.

Chamberlain, C.K., 1975, Recent Lebenspuren in nonmarine aquatic environments, in Frey, R.W., ed., The study of trace fossils: New York, Springer Verlag, p. 431458.

Chapman, R.H., and Bishop, C.C., 1975, Geophysical investigations in the Ione area, Amador, Sacramento, and Calaveras Counties, California: California Division of Mines and Geology Special Report 117, 27 p.

Clark, L.D., 1964, Stratigraphy and structure of part of the Western Sierra Nevada Metamorphic Belt: U.S. Geological Survey Professional Paper 410, 70 p.

Creely, R.S., 1965, Geology of the Oroville quadrangle, California: California Division of Mines and Geology Bulletin 184, 86 p.

Creely, R.S., 1997, Cherokee hydraulic mine, Butte County, California: geology and mining, in Erskine, M, and Lawler, D., eds., Northern Sierra region: Field trip guidebook, Northern California Geological Society, 25 p.

Creely, Scott, and Force, E.R., 1999, Depositional setting of the type Ione Formation (Eocene), Sierra Nevada foothills, California: Geological Society of America Abstracts with Programs v. 31, no. 6, p. A47.

Curran, H.A., 1985, The trace fossil assemblage of a Cretaceous nearshore environment: Englishtown Formation of Delaware, U.S.A., in Curran, H.A., ed. Biogenic structures--their use in interpreting depositional environments: Society of Economic Paleontologists and Mineralogists Special Publication 35, p. 261-276.

Dickerson, R.E., 1913, Fauna of the Eocene at Marysville Buttes, California: Berkeley, University of California, Bulletin of Geology Department, v. 7, p, 1-41

Dickerson, R.E., 1914, The Ione Formation of the Sierra Nevada foothills, a local facies of the upper Tejon-Eocene: Science v. 40, p. 67-70.

Dickerson, R.E., 1916, Stratigraphy and fauna of the Tejon Eocene of California: Berkeley, University of California, Bulletin of Geology Department, v. 9, p. 363-524.

Dietrich, W.F., 1928, The clay resources and the ceramic industry of California: California State Mining Bureau Bulletin 99, 383 p.

Ekdale, A.A., Bromley, R.G., and Pemberton, S.G., 1984, The use of trace fossils in sedimentology and stratigraphy: Society of Economic Paleontologists and Mineralogists, Tulsa, $234 \mathrm{p}$.

Force, E.R., 1991, Fluvial gold placers and basin-margin rotation: U.S. Geological Survey Open-File Report 91-306, 14 p. [http://pubs.er.usgs.gov/usgspubs/ofr/ofr91306 ]. 
Force, E.R., and Creely, Scott, 2000, Ione Formation, in Titanium-mineral resources of the western U.S.—an update: U.S. Geological Survey Open-File Report 00-442 [http://geopubs.wr.usgs.gov/open-file/of00-442/ ].

Force, E.R., and Lynd, L.E., 1984, Titanium-mineral resources of the United States: definition and documentation: U.S. Geological Survey Bulletin 1558-B, 11 p. [http://pubs.er.usgs.gov/usgspubs/b/b1558AB ].

Frey, R.W., Howard, J.D., and Pryor, W.A., 1978, Ophiomorpha: its morphologic, taxonomic, and environmental significance: Palæogeography, Palæoclimatology, Palæoecology, v. 23, p. 199-229.

Gillam, M.L., 1974, Contact relations of the Ione and Valley Springs Formations in the Buena Vista area, Amador County, California: Stanford University M.S. thesis, $180 \mathrm{p}$.

Glasmann, J.R., and Wood, J., 1995, Geology and geotechnical aspects of the Ione Formation: Sacramento, Guidebook American Association of Engineering Geologists.

Gomes, J.M., Martinez, G.M., and Wong, M.M., 1979, Recovering byproduct heavy minerals from sand and gravel, placer gold, and industrial mineral operations: U.S. Bureau of Mines Report of Investigations 8366, $15 \mathrm{p}$.

Grant, T.A., and McCleary, J.R., 1977, Correlation and dating of geomorphic and bedding surfaces on the east side of the San Joaquin Valley using dip, in Singer, M..J., ed., Soil development, geomorphology, and Cenozoic history of the northeastern San Joaquin Valley and adjacent areas: Geological Society of America field trip guidebook, University of California Press, Davis.

Hill, G.W., 1981, Ichnocoenoses of a Paleocene submarine canyon floor, Point Lobos, California, in Upper Cretaceous and Paleocene turbidites, central California coast, in V. Frizzell, ed.: Pacific Section Society of Economic Paleontologists and Mineralogists Book 20, p. 93-104.

Jenkins, O.R., 1948, Geologic history of the Sierran gold belt: California Division of Mines Bulletin 141, p. 23-28.

Johnson, H.R., 1943, Marysville Buttes (Sutter Buttes) gas field, in Geologic formations and economic development of the oil and gas fields of California: California Division of Mines Bulletin 118, p. 610-615.

Johnson, F.T., and Ricker, S., 1948, Ione-Carbondale clays, Amador County, California: U.S. Bureau of Mines Report of Investigation 4213.

Keller, W.D., 1982, Anauxite viewed by scanning electron microscopy: Clays and Clay Minerals, v. 30, p. 391-395.

Langston, R.B., and Pask, J.A., 1969, The nature of anauxite: Clays and Clay Minerals v. 16 , p. $425-436$.

Lindgren, Waldemar, 1894, Sacramento, California: U.S. Geological Survey Folio 5.

Lindgren, Waldemar, 1911, The Tertiary gravels of the Sierra Nevada of California: U.S. Geological Survey Professional Paper 73, 226 p.

Lindgren, W., and Turner, H.W., 1894, Description of the gold belt: U.S. Geological Survey Folio 3, p. 1-3.

Merrill, R.D., 1984, Ophiomorpha and other nonmarine trace fossils from the Eocene Ione Formation, California: Journal of Paleontology, v. 58, p. 542-549.

Morris, E.C., 1962, Mineral correlations of some Eocene sandstones of central California: Stanford University, Ph.D. dissertation, 113 p. 
Morris, P.A., 1966, A field guide to Pacific Coast shells, 2nd ed.: Boston, Houghton Mifflin Company.

Palmer, C.M., and Merrill, R.D., 1982, Braided-stream and alluvial-fan depositional environments in the lower to middle Eocene Ione Formation, Madera County, California, in Ingersoll, R.V., and Woodburne, M.O., eds., Cenozoic nonmarine deposits of California and Arizona: Society of Economic Paleontologists and Mineralogists, Pacific Section, 122 p.

Pask, J.A., and Turner, M.T., 1952, Geology and ceramic properties of the Ione Formation, Buena Vista area, Amador County, California: California Division of Mines Special Report 19, 39 p.

Piper, A.M., Gale, H.S., Thomas, H.E., and Robinson, T.W., 1939, Geology and groundwater hydrology of the Mokelumne area, California: U.S. Geological Survey Water-Supply Paper 780 [http://pubs.er.usgs.gov/usgspubs/wsp/wsp780 ].

Pryor, W.A., 1975, Biogenic sedimentation and alteration of argillaceous sediments in shallow marine environments: Geological Society of America Bulletin, v. 86, p. 1244-1254.

Rodgers, C.L., 1986, Depositional environments of the Ione Formation, east-central California: California State University at Fresno, M.S. thesis 114 p.

Ross, C.S., and Kerr, P.F., 1930, The kaolin minerals: U.S. Geological Survey Professional Paper 165-E, p., 151-176.

Schweickert, R.A., and Cowan, D.S., 1975, Early Mesozoic tectonic evolution of the western Sierra Nevada, California: Geological Society of America Bulletin, v. 86, p. 1329-1336.

Stewart, R., 1949, Lower Tertiary stratigraphy of Mount Diablo, Marysville Buttes, and west border of the lower Central Valley of California: U.S. Geological Survey Oil and Gas Investigation Preliminary Chart 34.

Turner, H.W., 1894, Jackson, California: U.S. Geological Survey Folio 11.

U.S. Army Corps of Engineers, 1995, Geologic and seismological investigation, New Hogan dam and reservoir, Calaveras County, California: Sacramento.

Wagner, D.L., 1981, Geologic map of the Sacramento quadrangle, California: California Division of Mines and Geology, scale 1:250,000.

Williams, Howel, 1929, Geology of the Marysville Buttes, California: University of California Bulletin of Department of Geological Sciences, v. 18, p. 103-220.

Williams, H., Turner, F.J., and Gilbert, C.M., 1982, Petrography ( $2^{\text {nd }}$ ed.): San Francisco, W.H. Freeman.

Wollenburg, H.A., and Dodge, F.C.W., 1973, Radioelement and trace-element content of the Ione Formation, central California: U.S. Geological Survey Bulletin 1382-B, 17 p. [http://pubs.er.usgs.gov/usgspubs/b/b1382B ].

Wood, J.L., 1994, A re-evaluation of the origin of kaolinite in the Ione depositional system (Eocene), Sierra foothills, California: University of California at Los Angeles, M.S. thesis, $211 \mathrm{p}$.

Wood, J.L., Glasmann, J.R., and Stout, S.A., 1995, Geology of the Eocene Ione Formation, Ione area, California, in Geology and geotechnical aspects of the Ione Formation: Association of Engineering Geologists field trip guide Oct. 3, 1995, p. $9-45$. 
Table 1. Generalized character of specimens of Ione Formation as functions of stratigraphic level and areal location. Grain sorting and angularity, abundance of detrital feldspar, chert, and clay grains, and heavy mineral assemblage listed in that order.

Abbreviations are for opaque minerals, zircon, tourmaline, andalusite, ilmenite-hematite, epidote, rutile, and clinozoisite.

\begin{tabular}{|c|c|c|c|}
\hline & North end & Central basin & South end \\
\hline $\begin{array}{l}\text { Above Ione Sand } \\
\text { member }\end{array}$ & $\begin{array}{l}\text { Sorted (clay cement) } \\
\text { Subangular } \\
\text { Non-feldspathic } \\
\text { Opaq >zirc=tour=andal }\end{array}$ & $\begin{array}{l}\text { Moderate sorting } \\
\text { Subangular } \\
\text { Non-feldspathic, } \\
\text { abundant detrital clay } \\
\text { including anauxite } \\
\text { Opaq=andal }\end{array}$ & $\begin{array}{l}\text { Poor sorting } \\
\text { Subangular } \\
\text { Non-feldspathic } \\
\text { Ilm-hem }>\text { zirc= } \\
\text { tour }>\text { clnzoisite }\end{array}$ \\
\hline $\begin{array}{l}\text { Ione Sand interval } \\
\text { member }\end{array}$ & $\begin{array}{l}\text { Moderate sorting (anauxite } \\
\text { and claystone as clasts) } \\
\text { Subangular } \\
\text { Non-feldspathic } \\
\text { Ilm>zirc }>\text { ep=rut=tour }> \\
\text { andal }\end{array}$ & $\begin{array}{l}\text { Moderate sorting (clay } \\
\text { as clasts) } \\
\text { Subangular } \\
1-5 \% \text { feldspar, detrital } \\
\text { clay includes anauxite, } \\
\text { glauc } \\
\text { Opaq>zirc>tour> } \\
\text { andal>rut }\end{array}$ & $\begin{array}{l}\text { Sorted } \\
\text { Subangular } \\
1-10 \% \text { feldspar, } \\
\text { abundant clay clasts } \\
\text { include anauxite } \\
\text { Opaq>zirc=tour }\end{array}$ \\
\hline $\begin{array}{l}\text { Below Ione Sand } \\
\text { member }\end{array}$ & $\begin{array}{l}\text { Moderate sorting } \\
\text { Variable angularity } \\
\text { Non-feldspathic but detrital } \\
\text { chert, clay } \\
\text { Ilm }>\text { zirc }>\text { rut=ep=tour= } \\
\text { andal }\end{array}$ & $\begin{array}{l}\text { Poor to moderate sorting } \\
\text { Angular } \\
\text { Non-feldspathic, locally } \\
\text { clayey } \\
\text { Opaq>zirc }\end{array}$ & $\begin{array}{l}\text { Poor to moderate sorting } \\
\text { Subrounded } \\
\text { Non-feldsapthic but } \\
\text { cherty } \\
\text { Ilm }>\text { zirc }>\text { ep=andal }>\text { rut= } \\
\text { tour }\end{array}$ \\
\hline
\end{tabular}




\section{Figures}

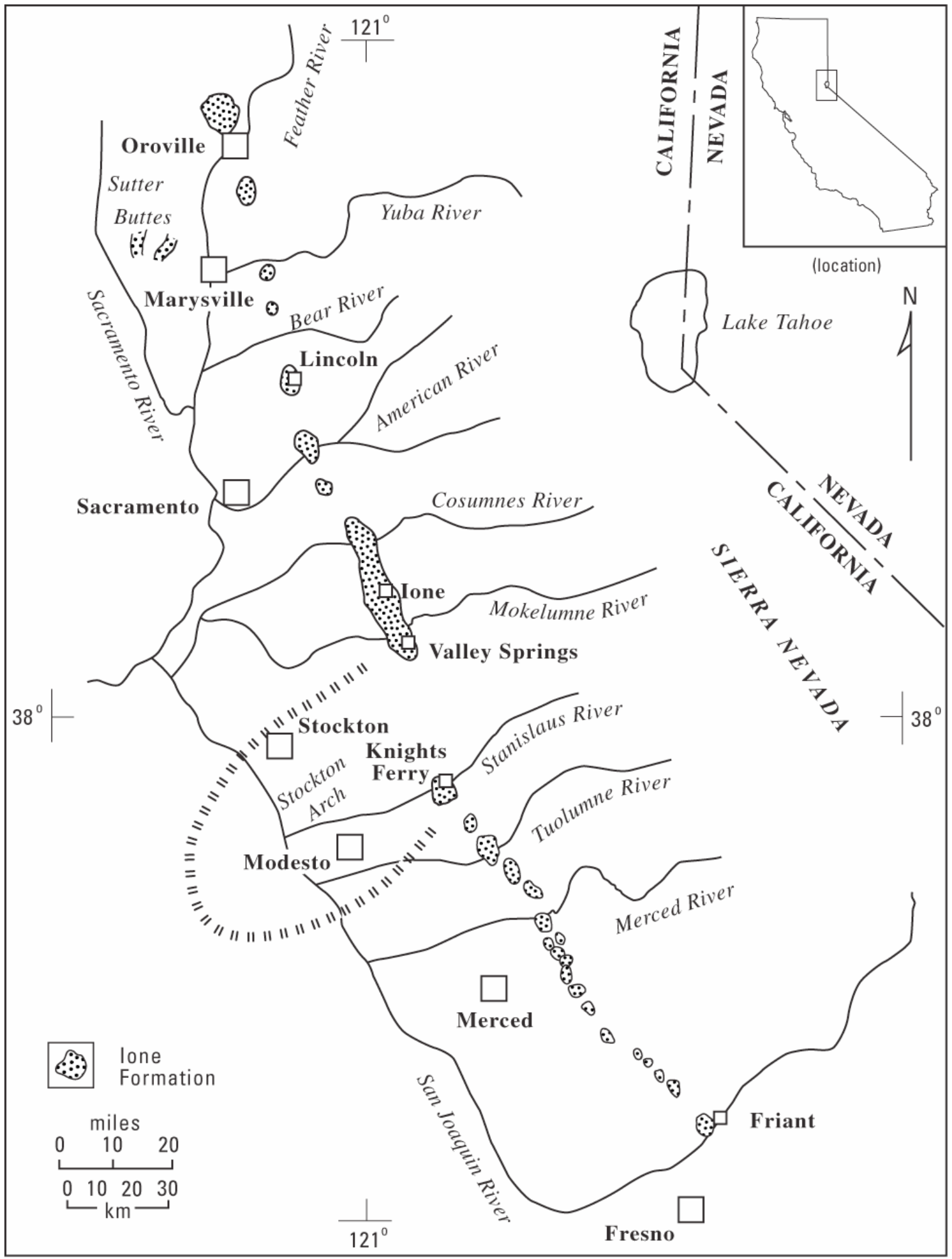

Figure 1. Surface distribution of the Ione Formation in central and northern California. 


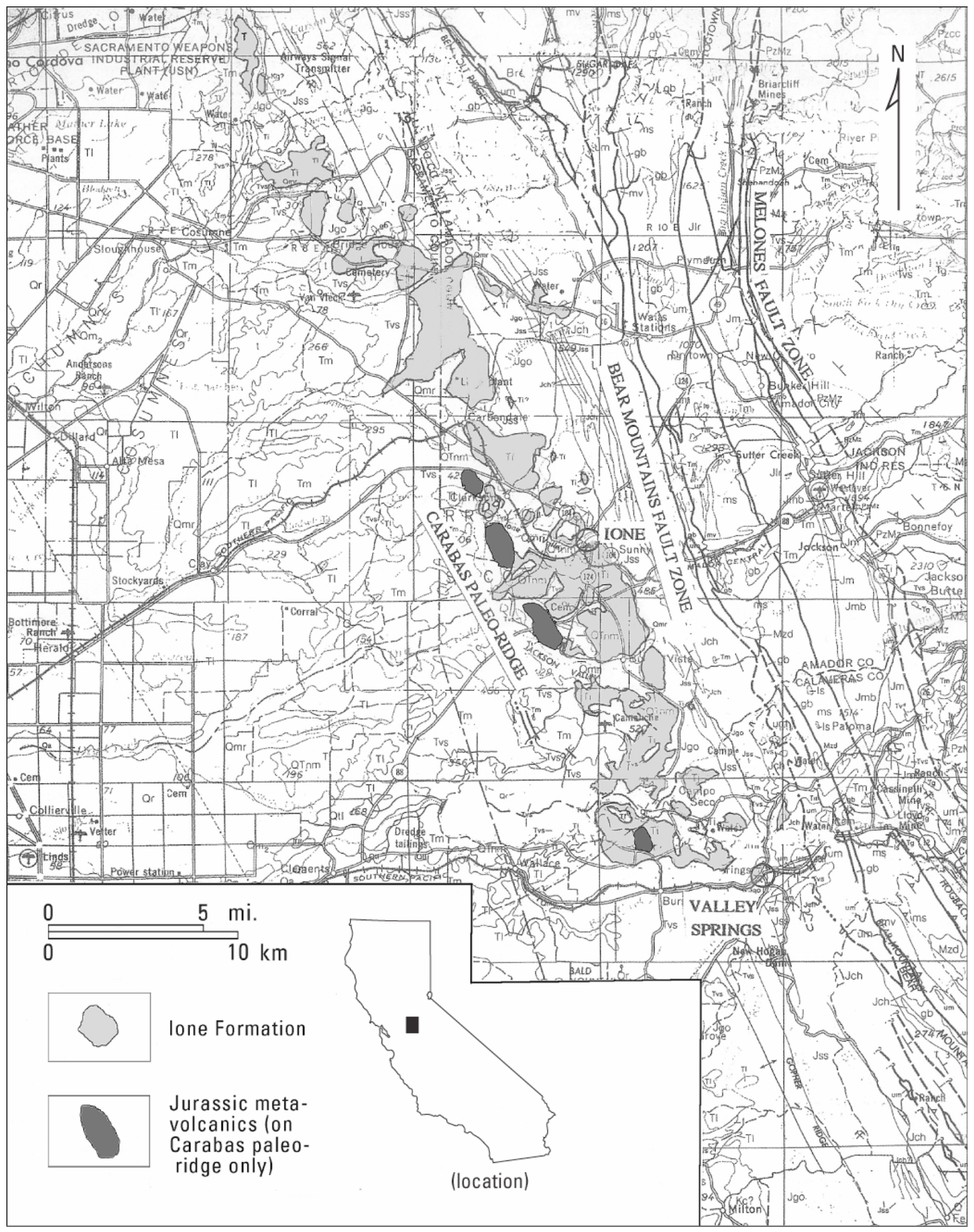

Figure 2. Areal geologic map of the Ione Formation in its type area, from Wagner and others (1981). 


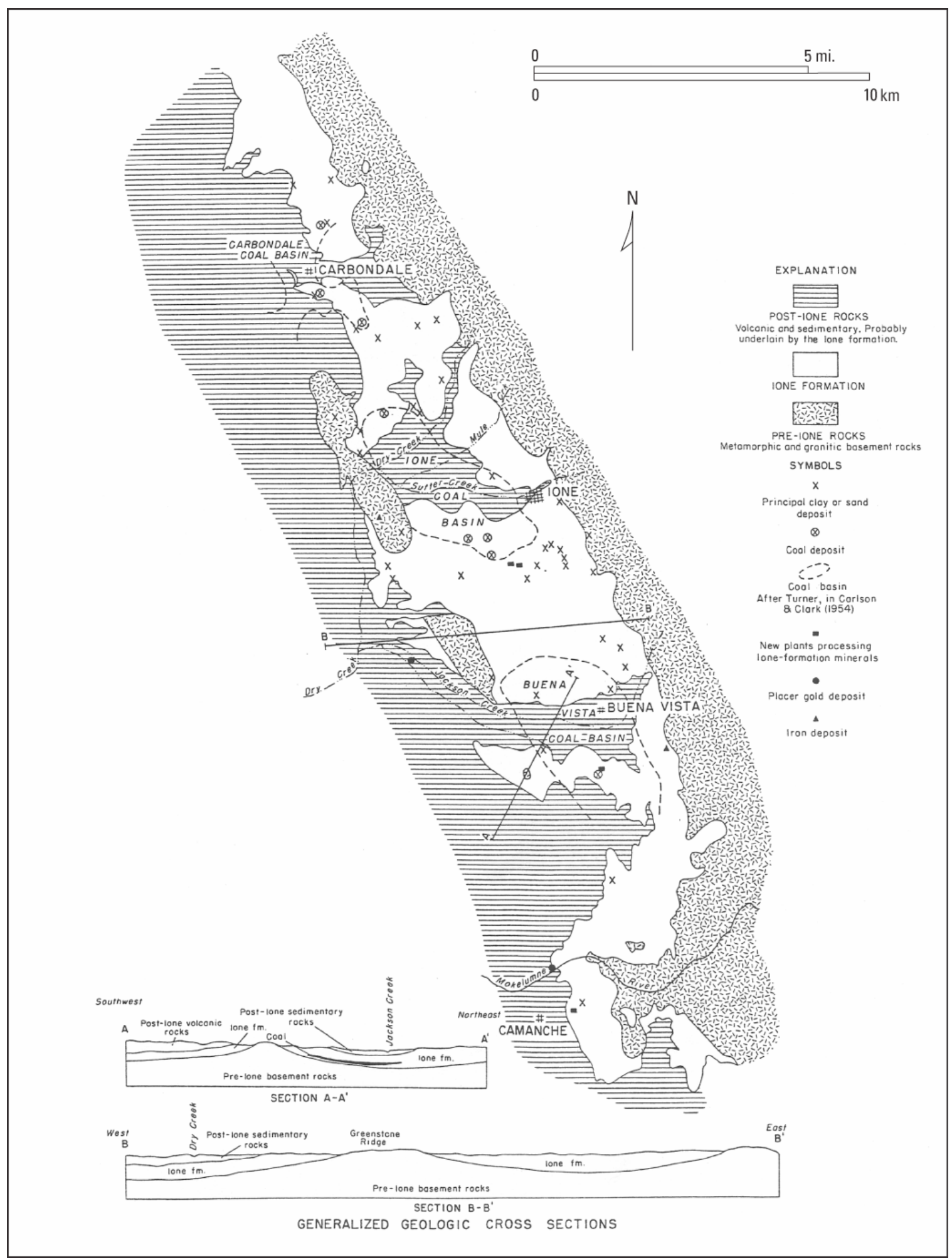

Figure 3. Mineral deposits of the type area of the Ione Formation in relation to geology, from Piper and others (1939). 


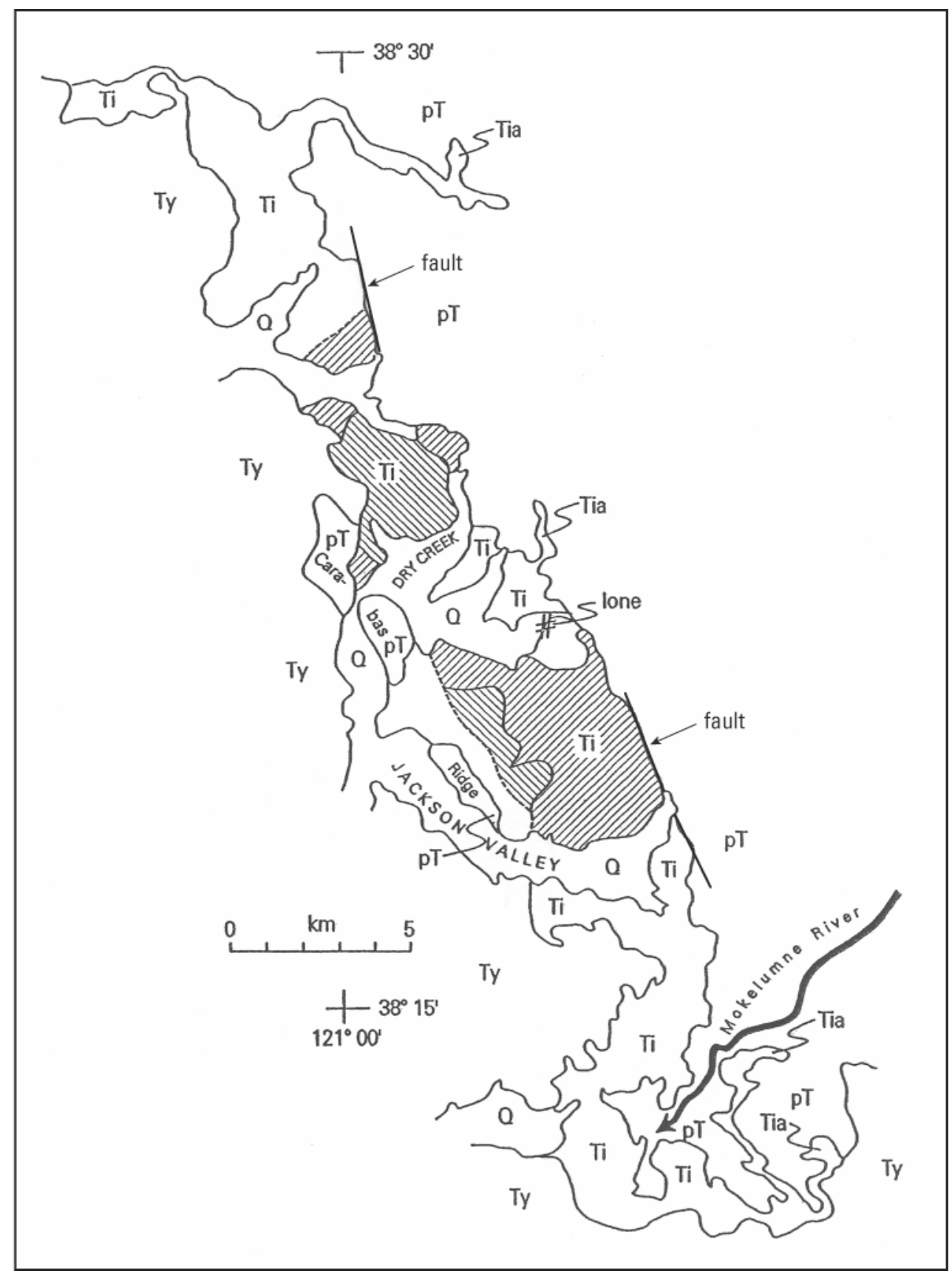

Figure 4. Geologic map emphasizing Ione Sand member from Force and Creely (2000), to which we have added faults. Units (from oldest to youngest) are pT, pre-Tertiary bedrock; Ti, Ione Formation including Tia, "auriferous gravel" facies; Ty, younger Tertiary units; Q, Quaternary. NE-SW lined pattern is surface distribution, NW-SE lined pattern is subsurface. 


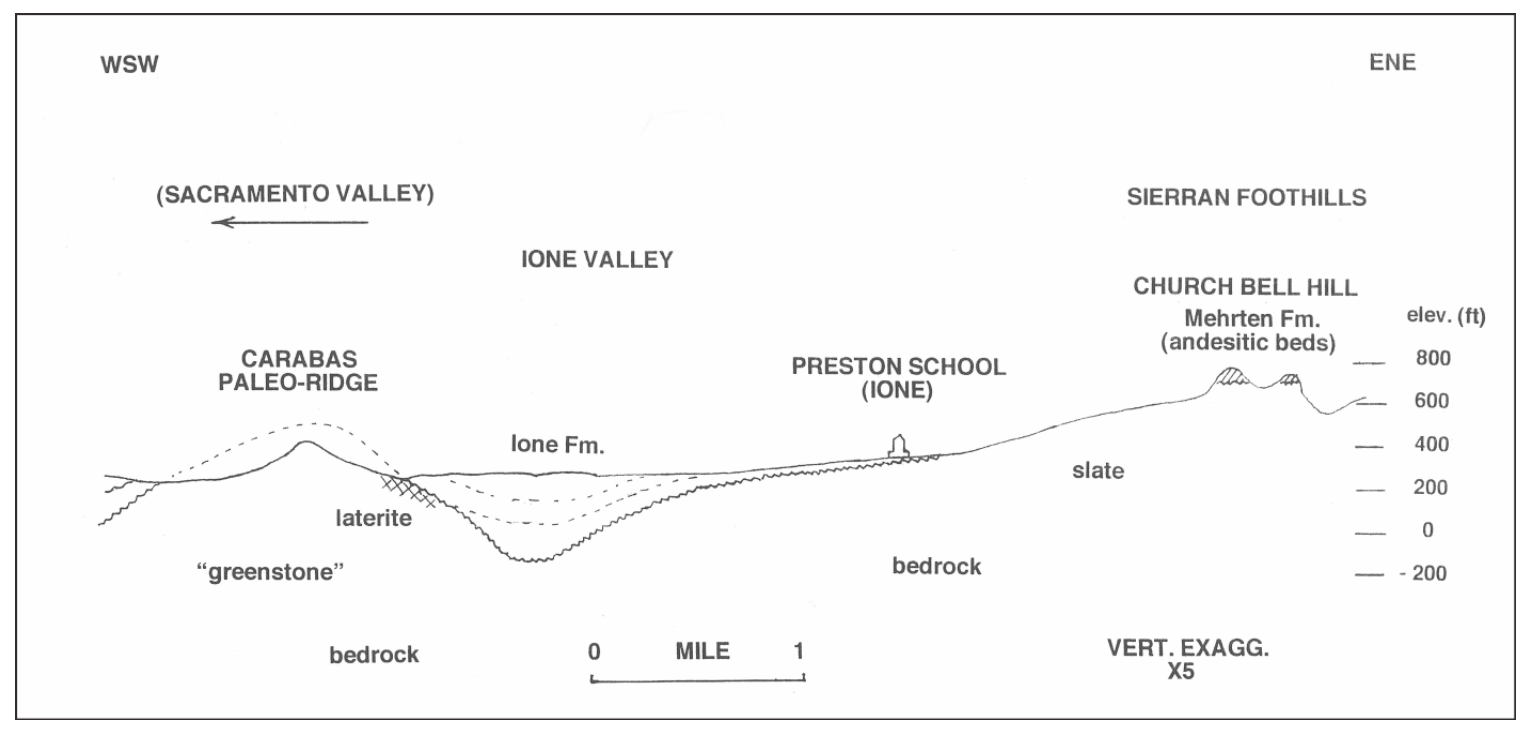

Figure 5. Generalized structure section across Ione Formation in type area. 


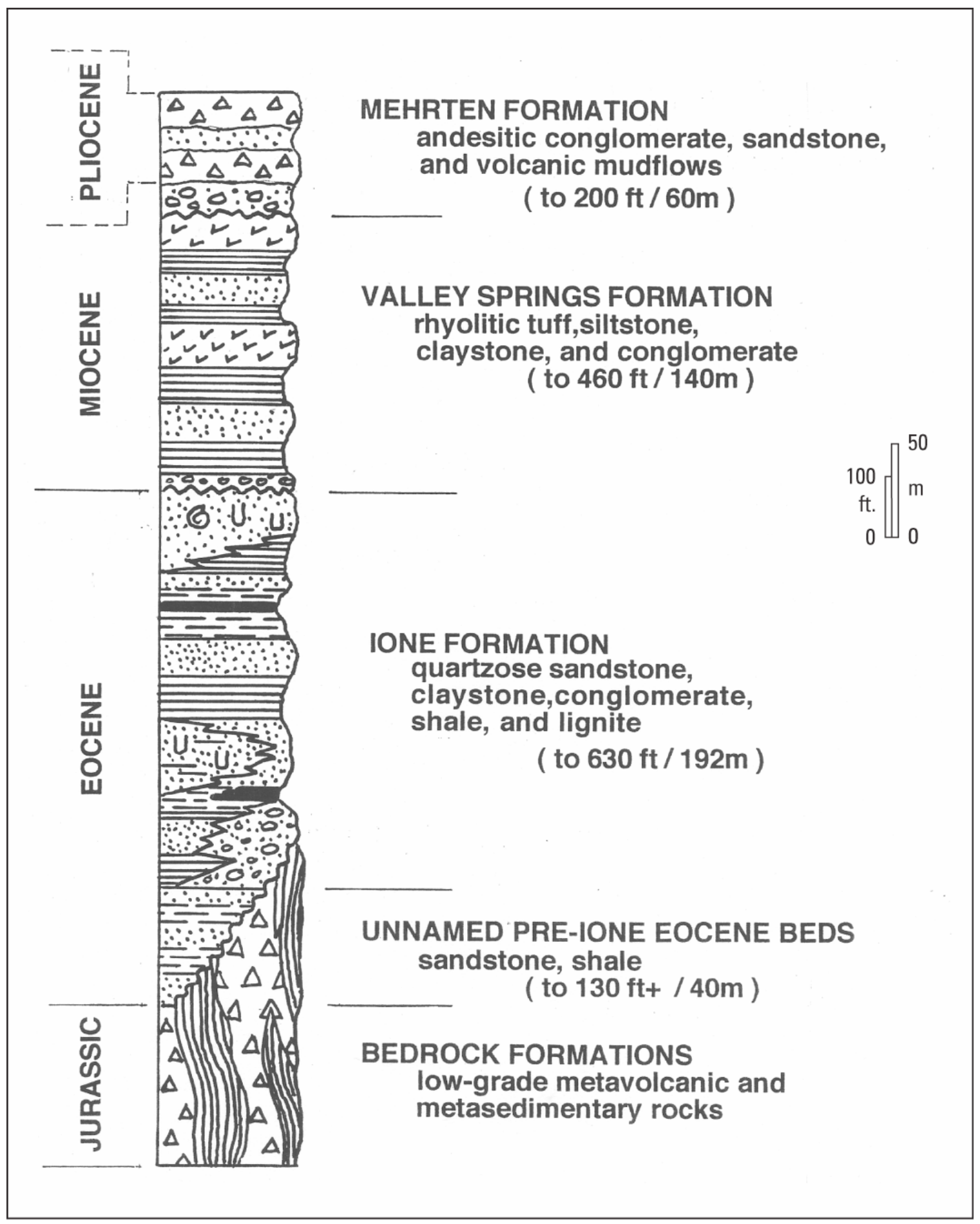

Figure 6. General stratigraphic column for western Amador County, California.. 


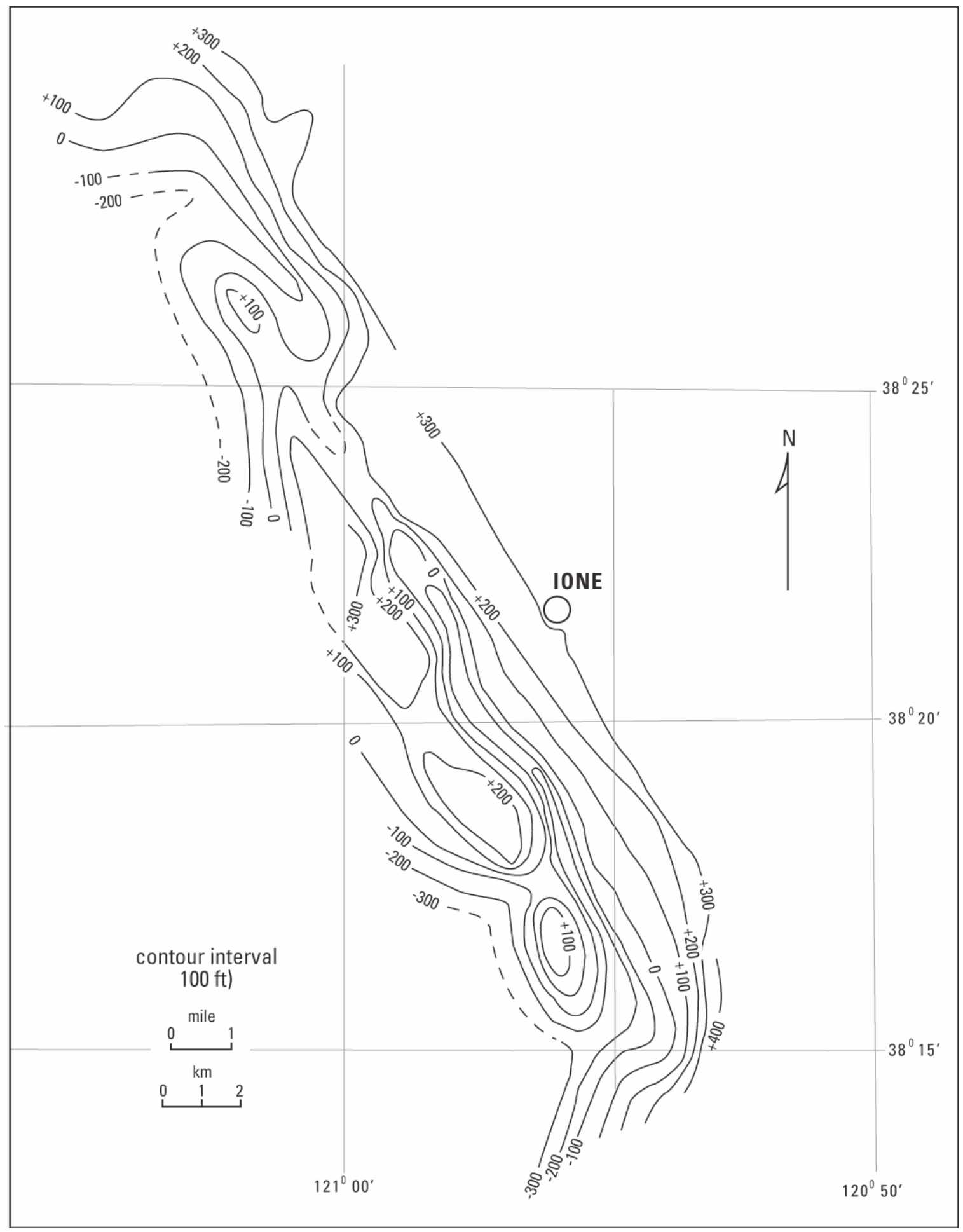

Figure 7. Contour map of basement surface (after Chapman and Bishop, 1975). 


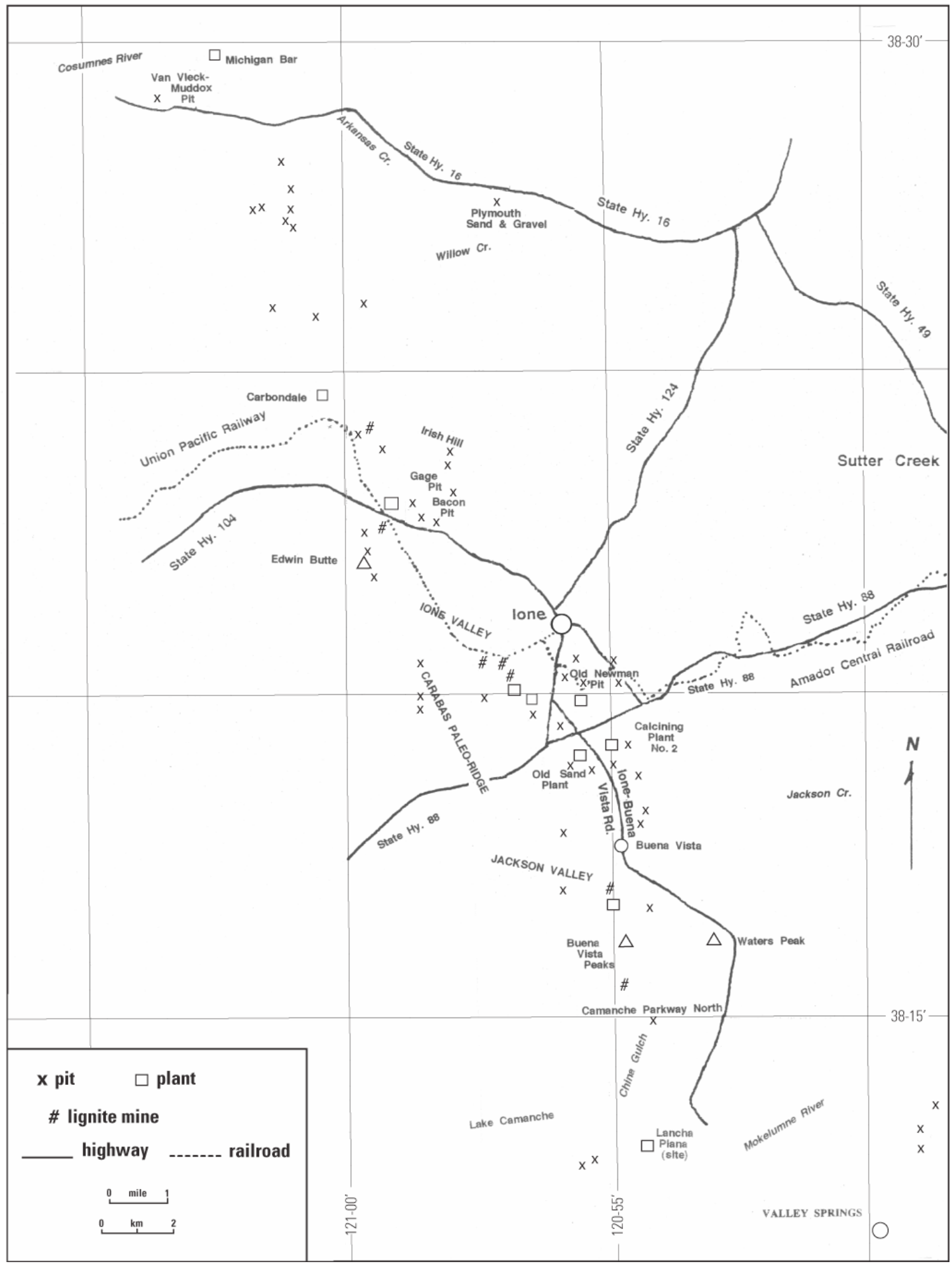

Figure 8. Geographic map of the type region of the Ione Formation, showing location of features cited in text, clay and/or sand pits, lignite mines, and processing plants. 


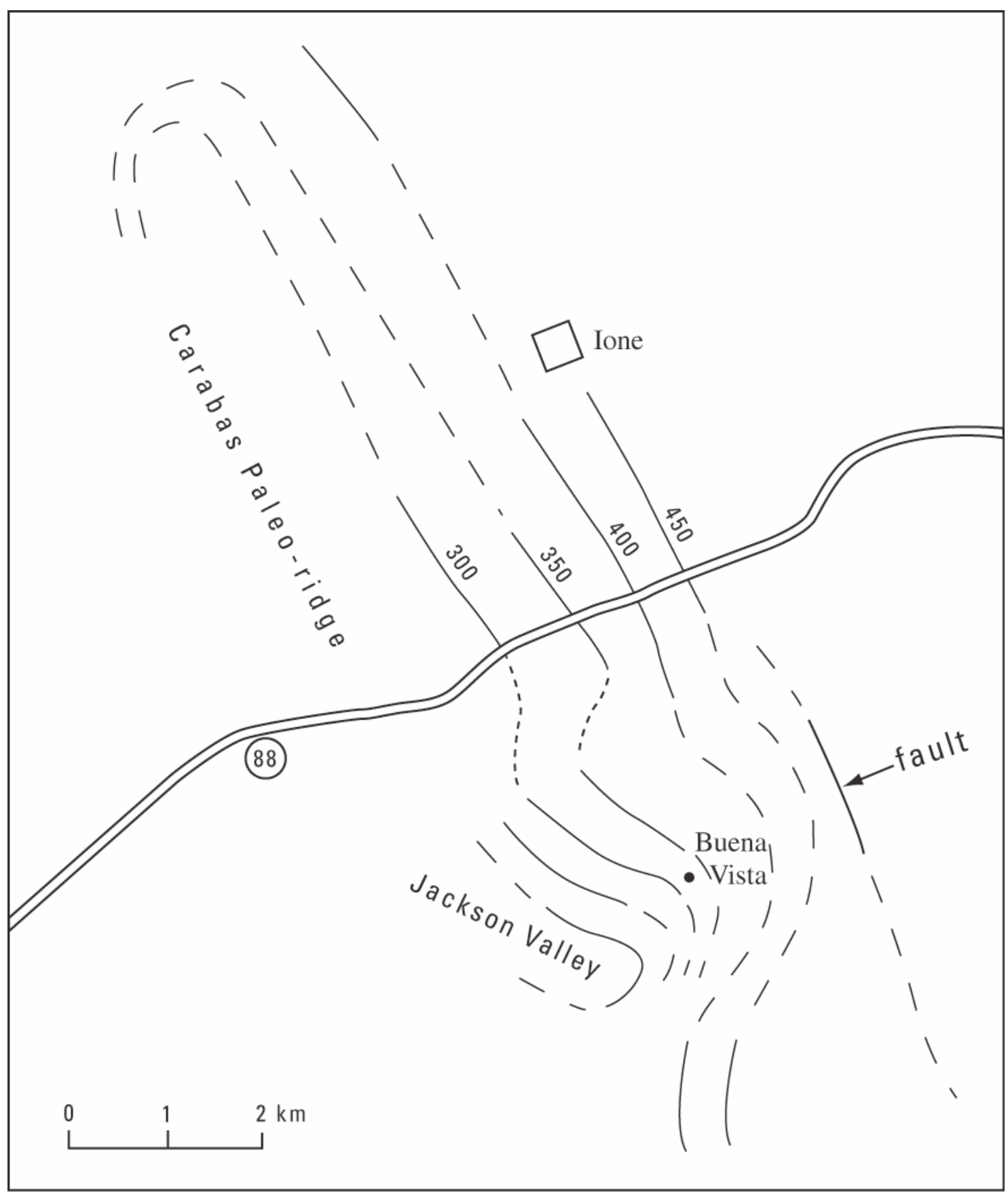

Figure 9. Structure contours (in feet) on top of lower marine interval in the Ione area. Also shown (south of highway 88) are contours on the top of Pask and Turner's (1952) lower member near Jackson Valley (correlation of the two data sets is shown by dots) and one of the faults on the eastern margin of the basin. 


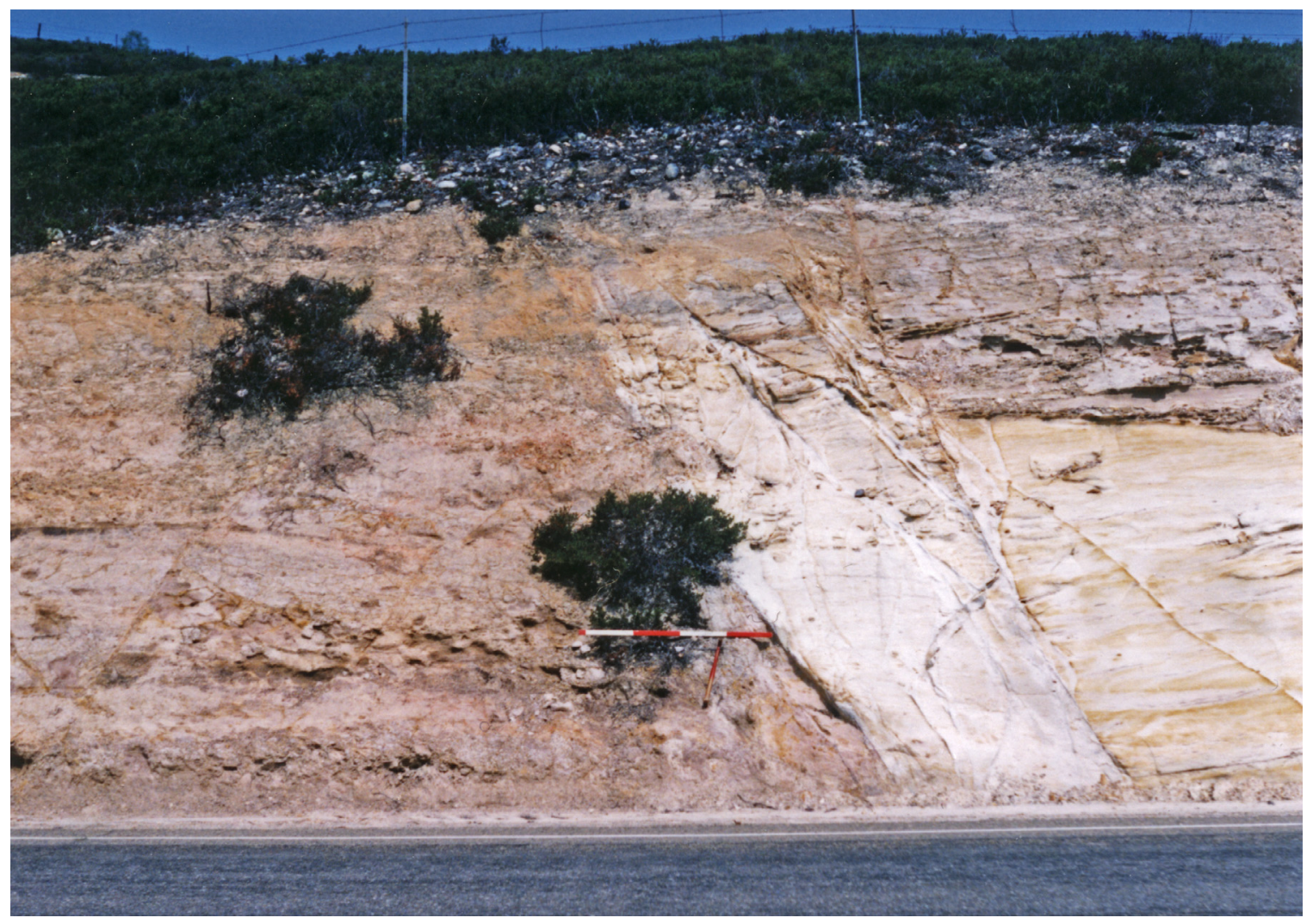

Figure 10. Small normal-slip faults in shear zone. Coastal floodplain shaly beds on left vs. probably estuarine sandstone (Ione Sand member) on right. Staff in lower-center is $4 \mathrm{ft}$. long. Camanche Parkway North near China Gulch.

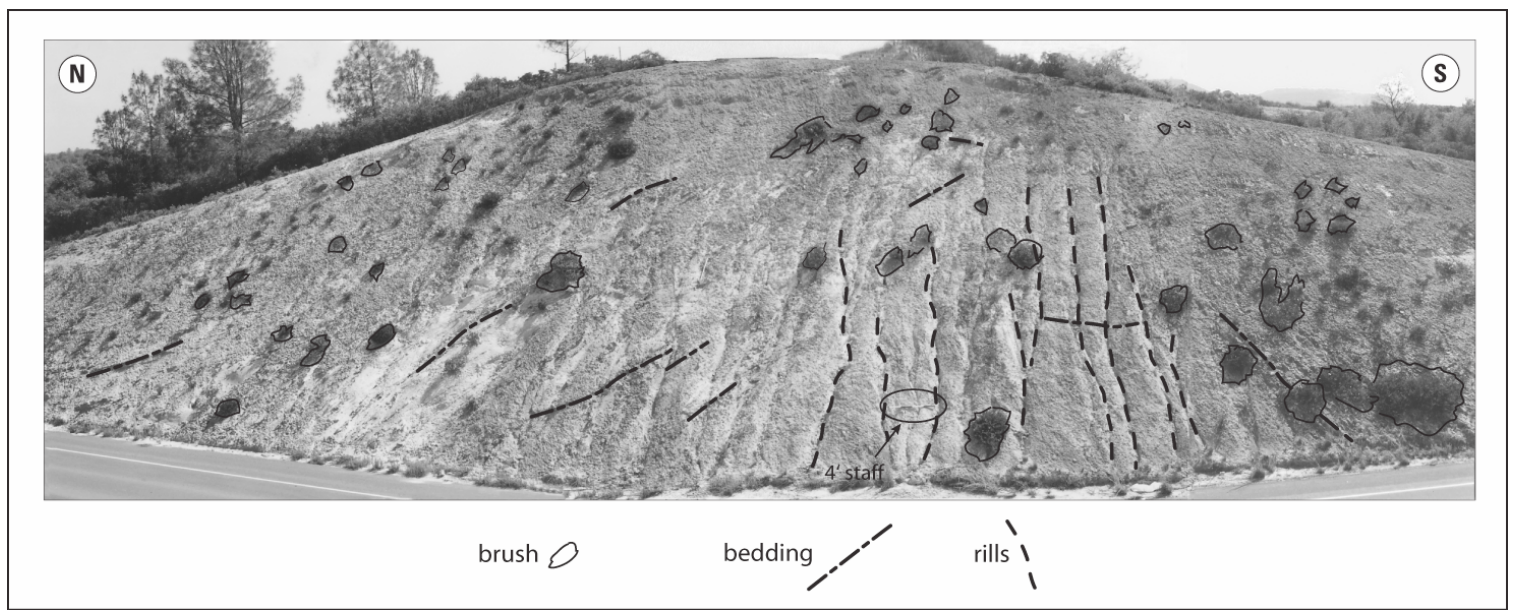

Figure 11. Annotated photo of small tight anticline in thin-bedded shale and sandstone; interpreted as a probable mud diapir. Roadcut on east side of state highway 124 about 1 mile south of Ione. Staff (arrow) is $4 \mathrm{ft}$. long. 


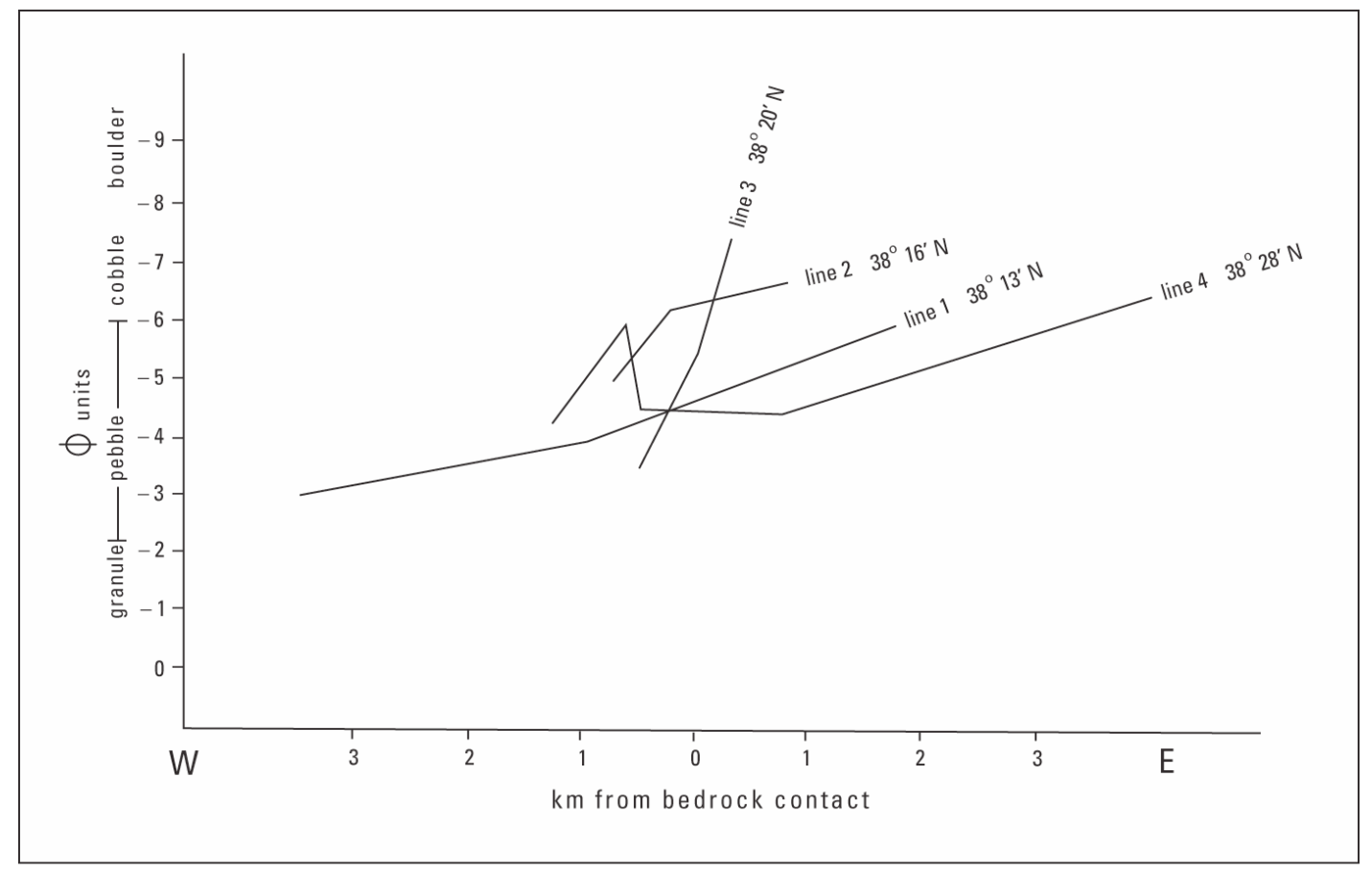

Figure 12. Diagram of maximum clast size of non-marine gravels (in approximate phi units, from generalized field descriptions) as a function of E-W location relative to the contact of continuous Ione Formation with bedrock to the east. Locations are grouped into four cross-sections numbered from north to south. Local reversals can occur (as in curve 4) where dip of the beds brings a new horizon to the surface, but all the localities used expose a considerable thickness of non-marine gravels. Faults are neglected in these plots because horizontal extension relative to map distance is thought to be minor.

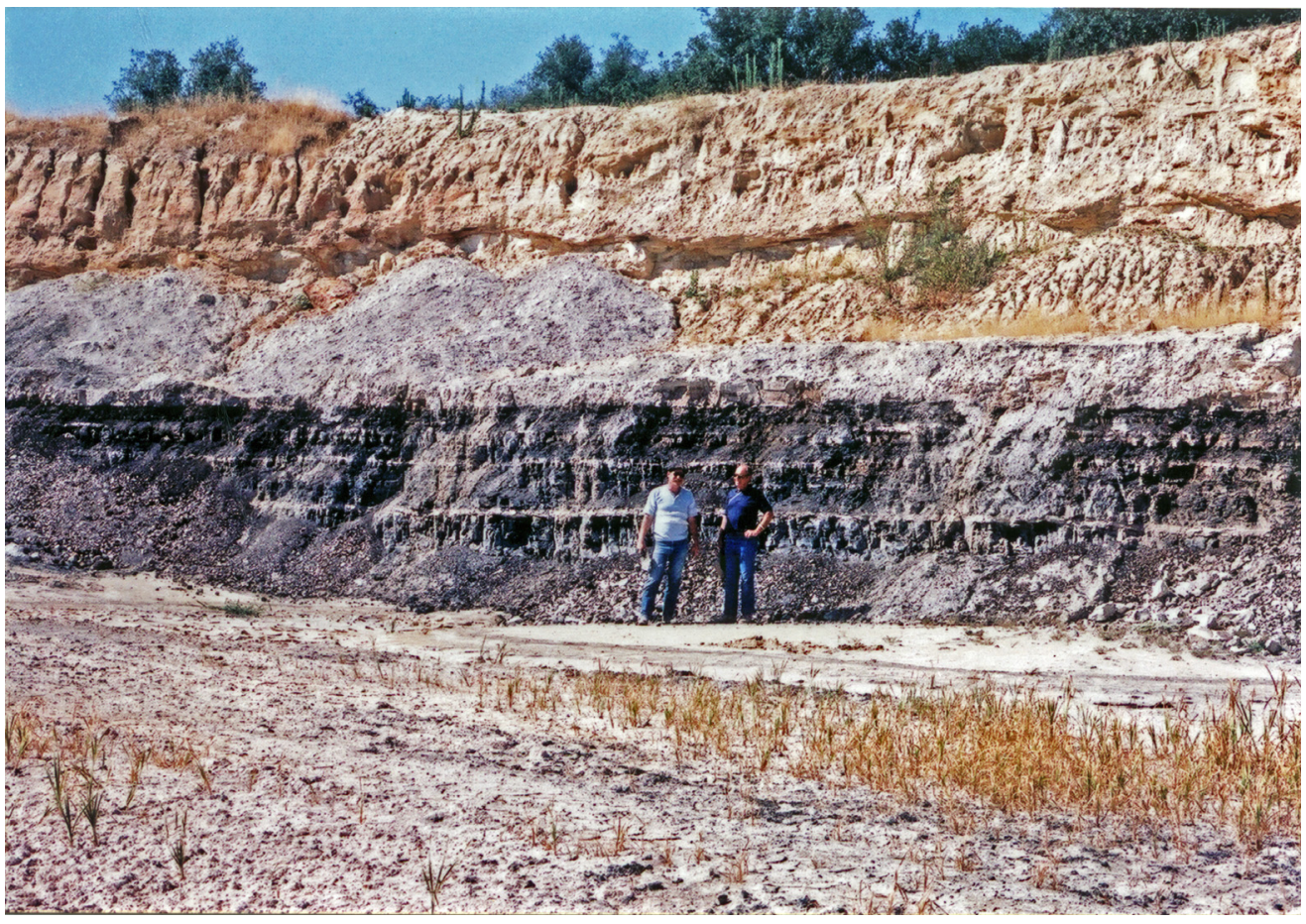

Figure 13. Lignite bed ( $2 \mathrm{~m}$ thick) in lower Ione Formation, Berry Pit SE about $2 \mathrm{~km}$ (1.2 mi) SE of Buena Vista. 


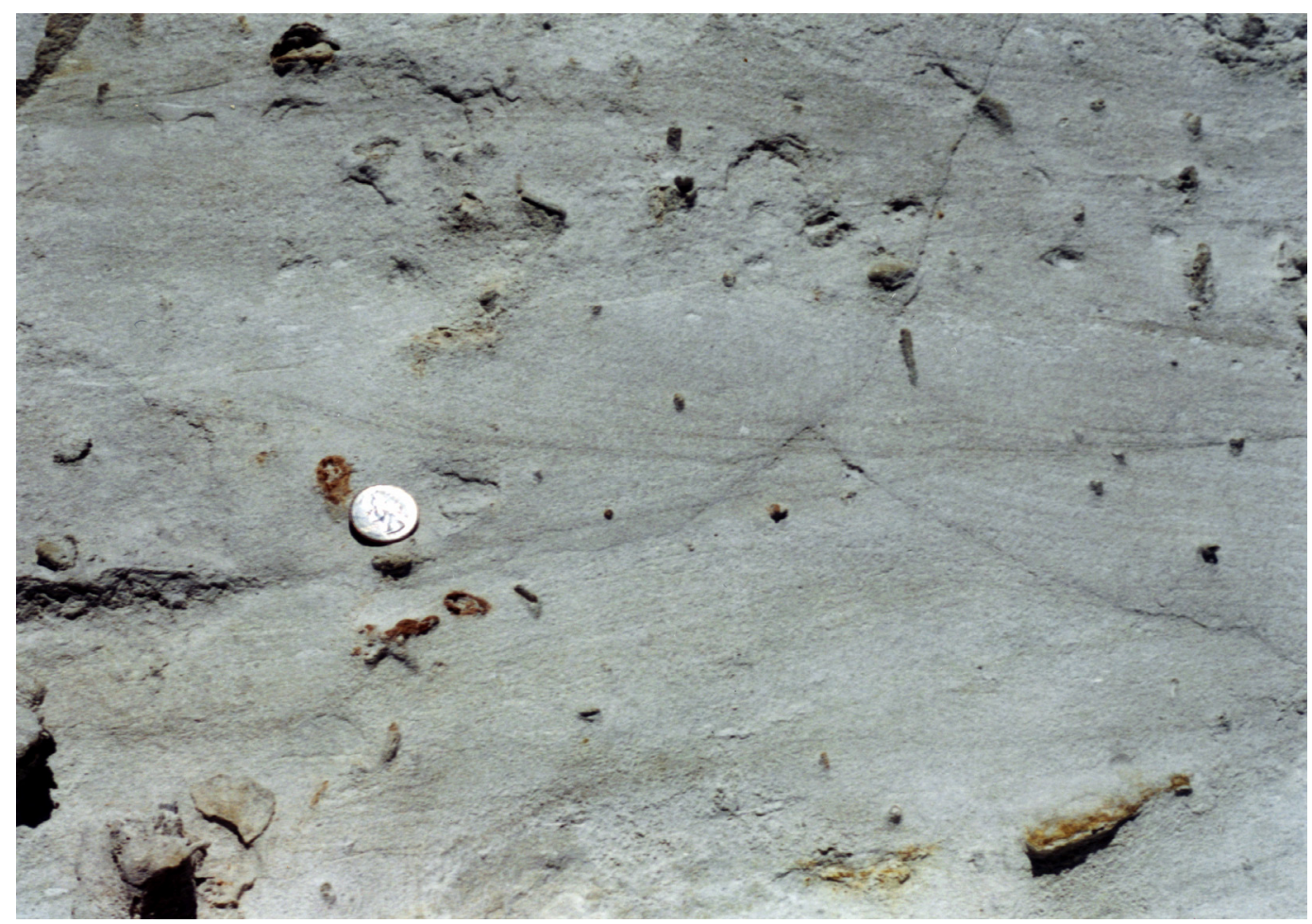

Figure 14. Unconformities, burrows, and low-angle cross-bedding in shoreline sandstone expressed by heavy mineral laminations in Ione Sand member. Coin is $24 \mathrm{~mm}$ in diameter. Roadcut on Ione-Buena Vista Road $1500 \mathrm{ft}$. $(0.5 \mathrm{~km}) \mathrm{NW}$ of state highway 88 .

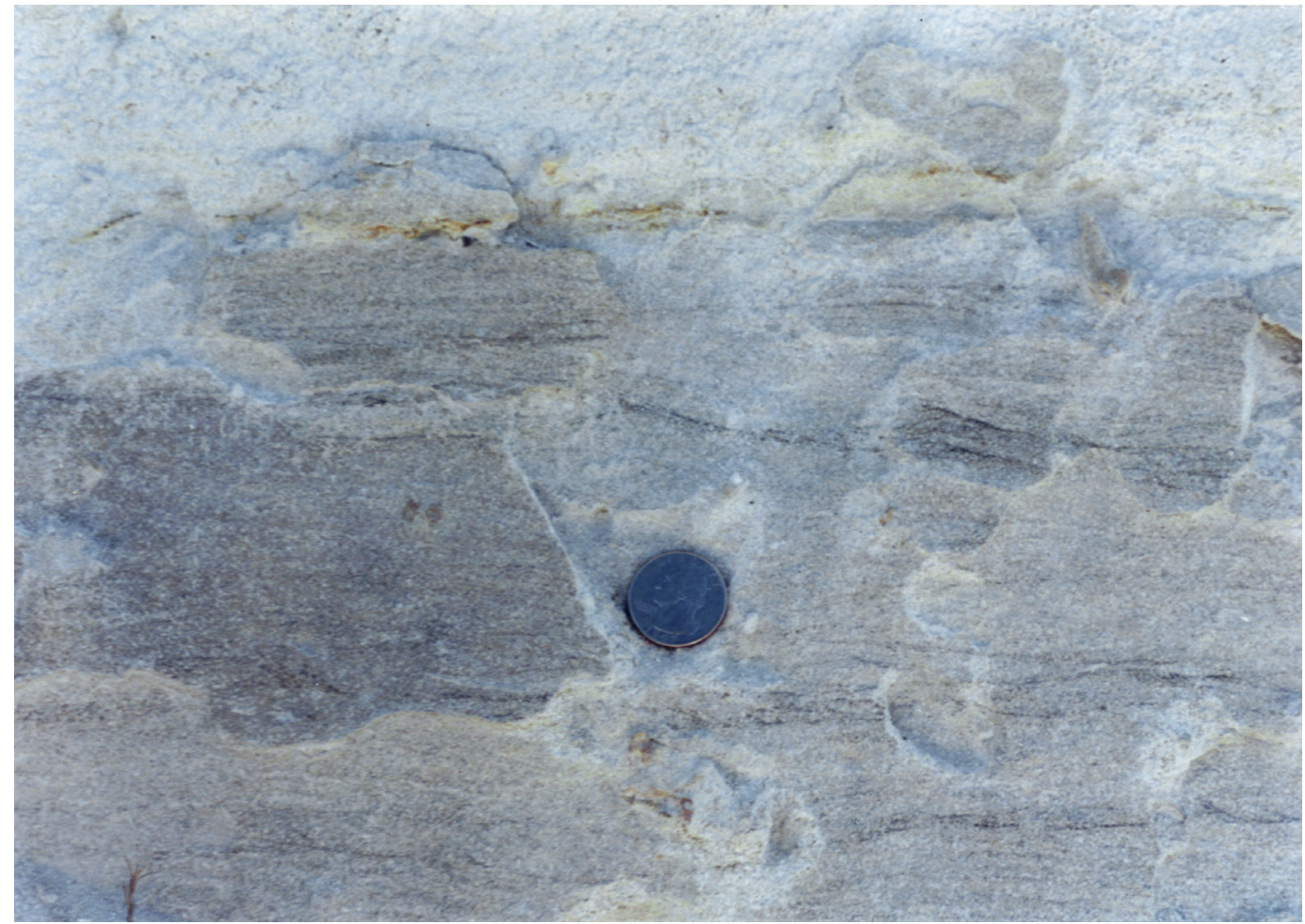

Figure 15. Low-angle cross-bedding in shoreline sandstone expressed by heavy mineral laminations in Ione Sand member. Coin is $24 \mathrm{~mm}$ in diameter. Roadcut on Ione-Buena Vista Road $1500 \mathrm{ft}$. $(0.5 \mathrm{~km}) \mathrm{NW}$ of state highway 88. 


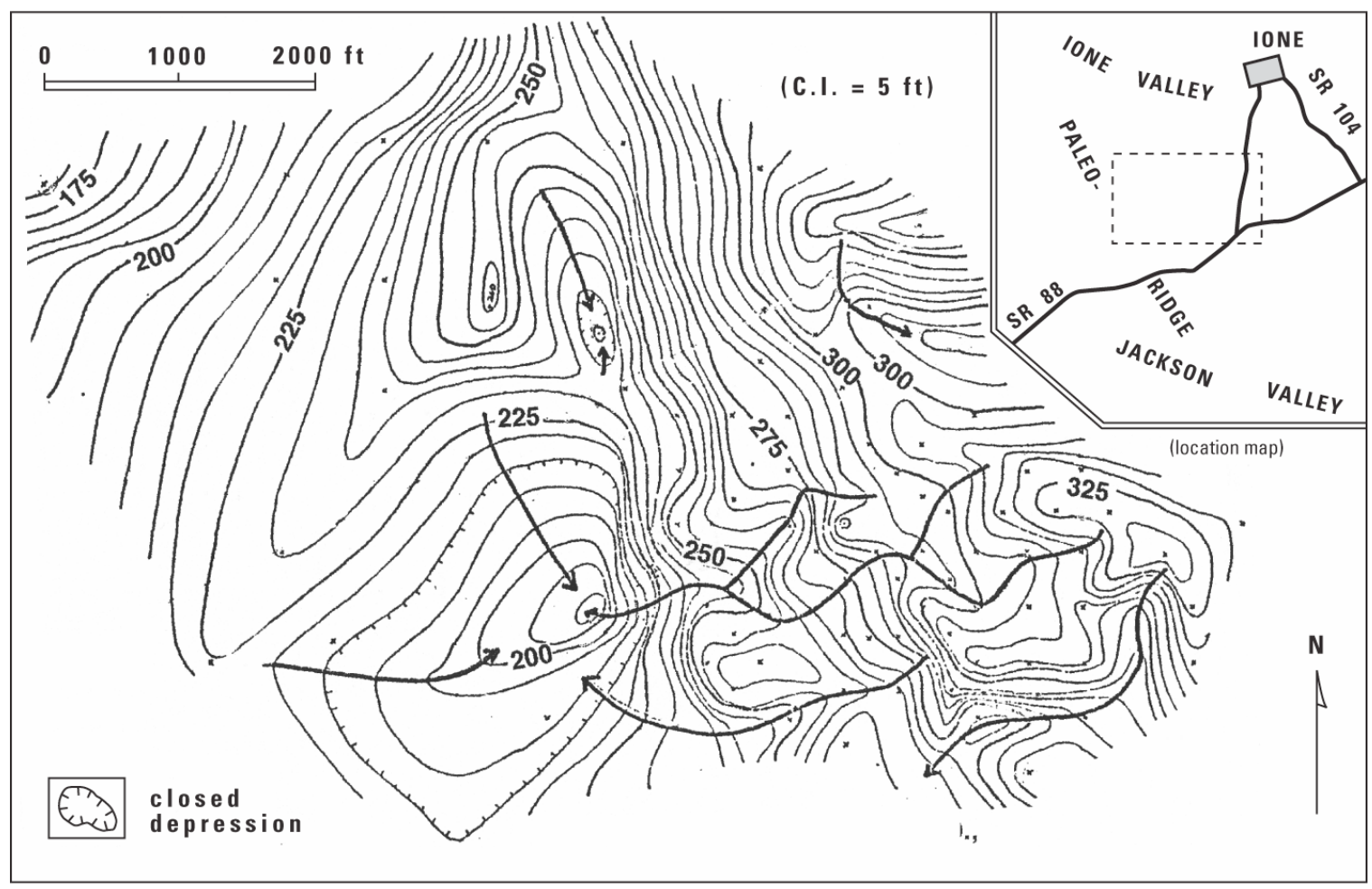

Figure 16. Structure contour map on the top of Ione Sand member. Owens-Illinois data via Gillam (1974).

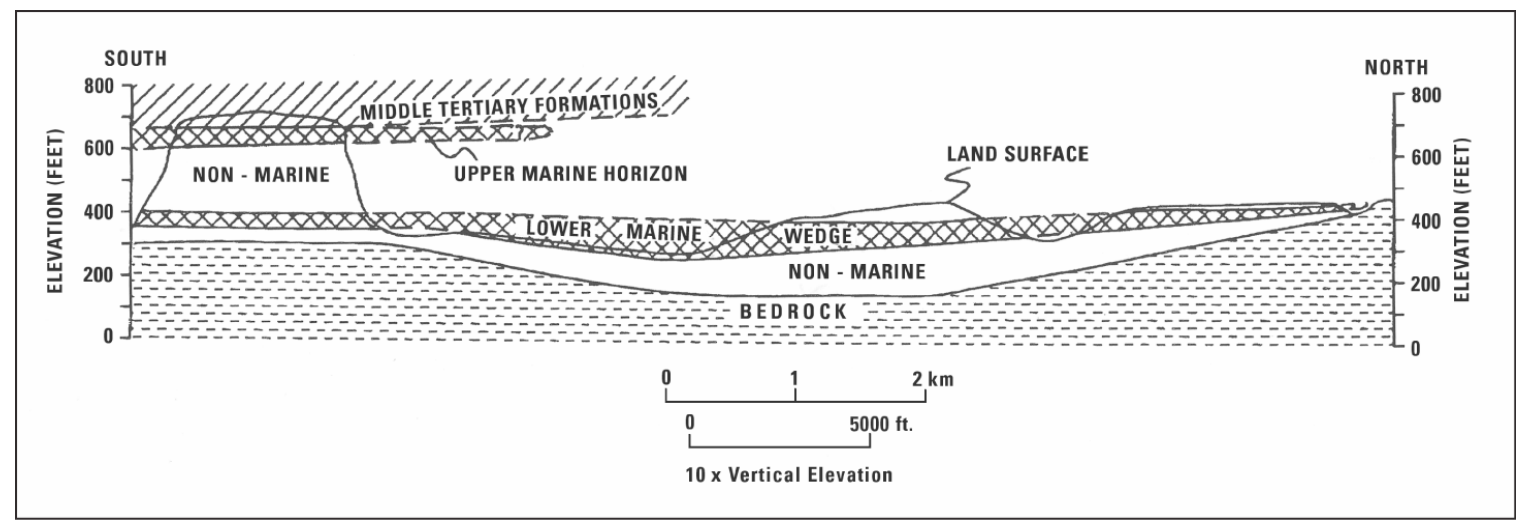

Figure 17. North-south cross-section showing relation and extent of marine horizons, from the Camanche North Parkway at China Gulch to the Custer and Old Newman pits at Lanes (see fig. 8 for locations). 


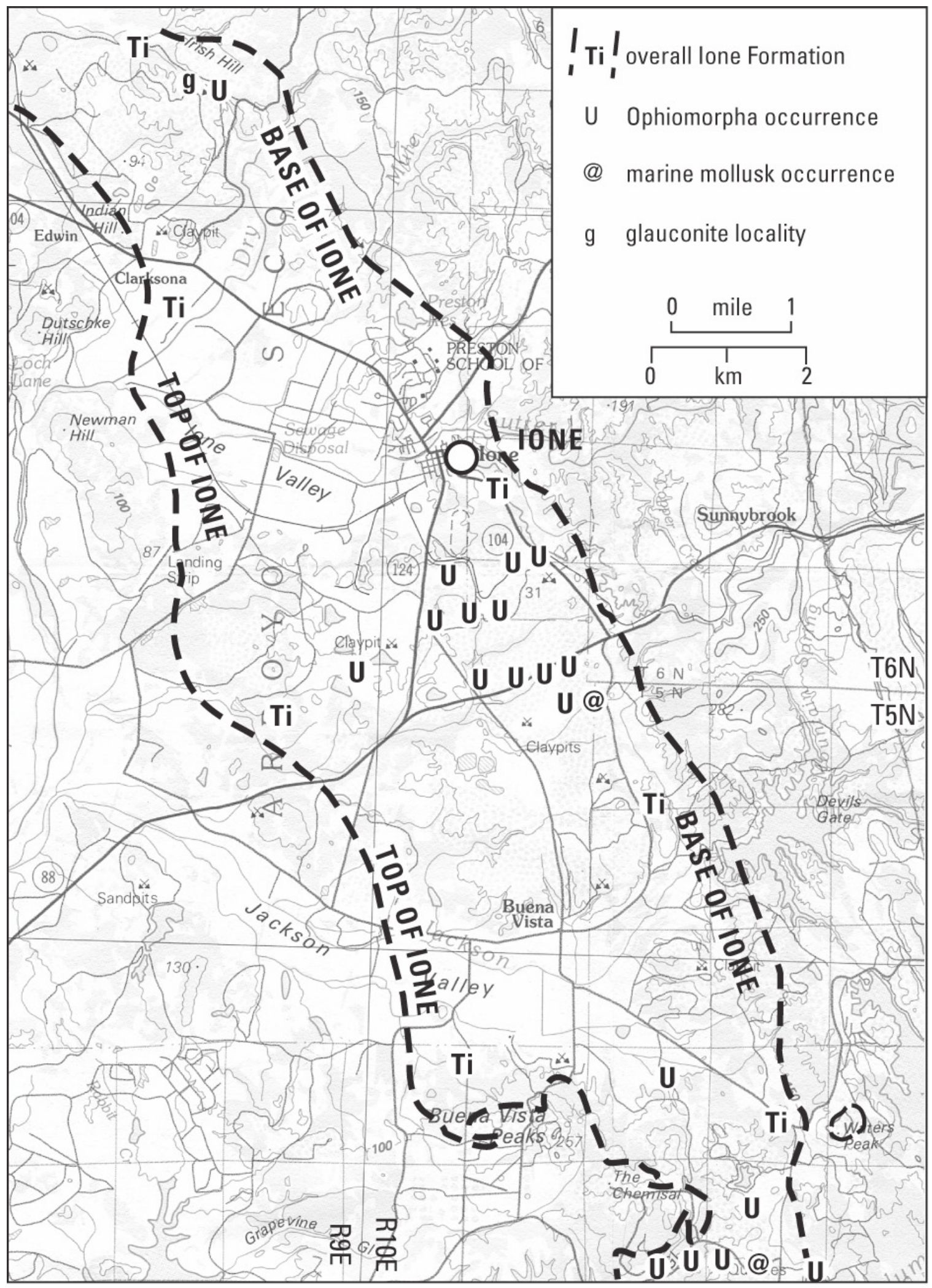

Figure 18. Distribution of Ophiomorpha, other marine fossils, and glauconite (near Gage Pit) in outcrop belt of Ione Formation in its type area. Outline of overall Ione Formation is based on compilation by Bartow and Marchand, 1979. 


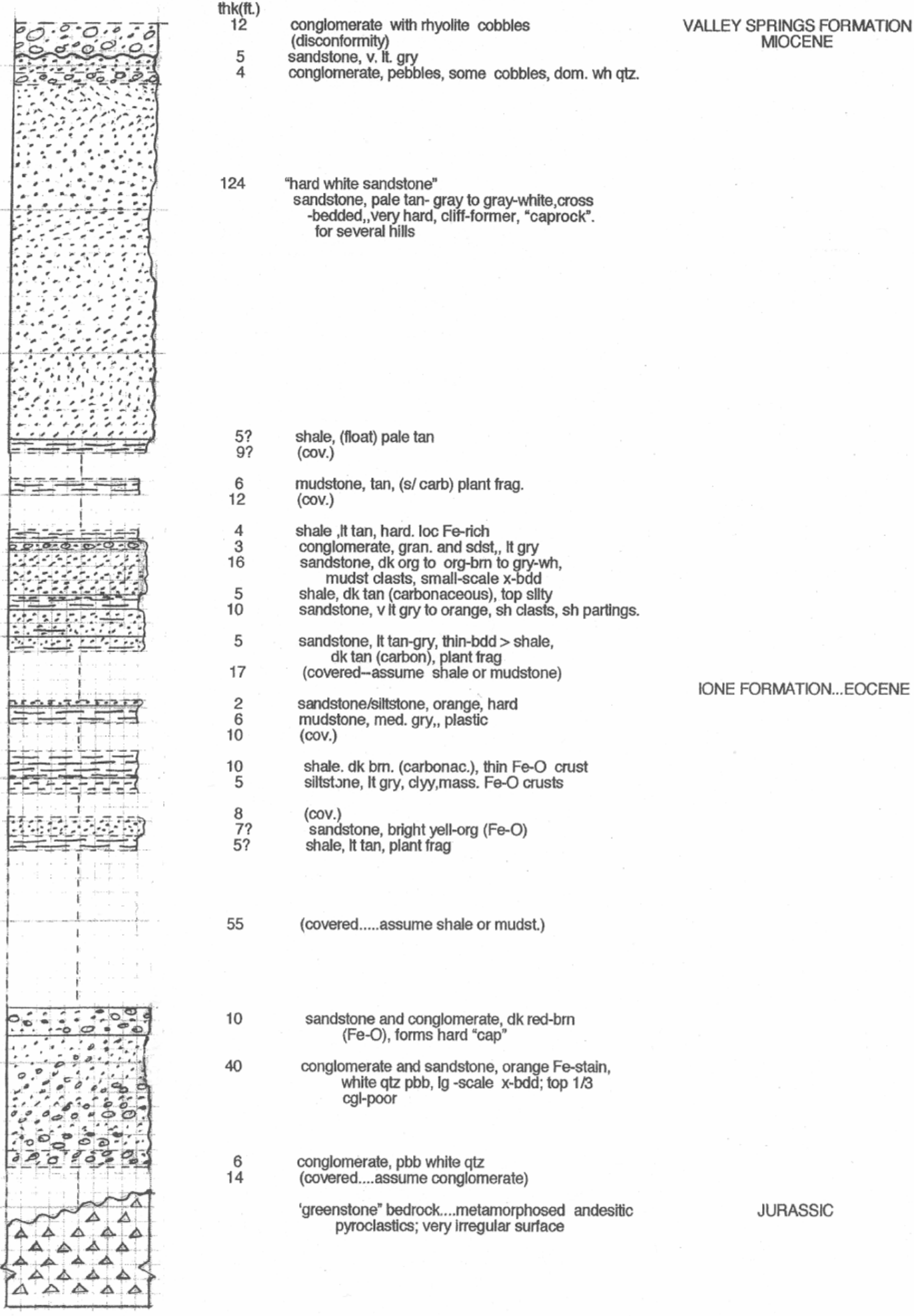

Figure 19. Stratigraphic sections of the Ione Formation (locations in figure 8): A. Measured section in hills north of Lancha Plana, possibly all marine. 


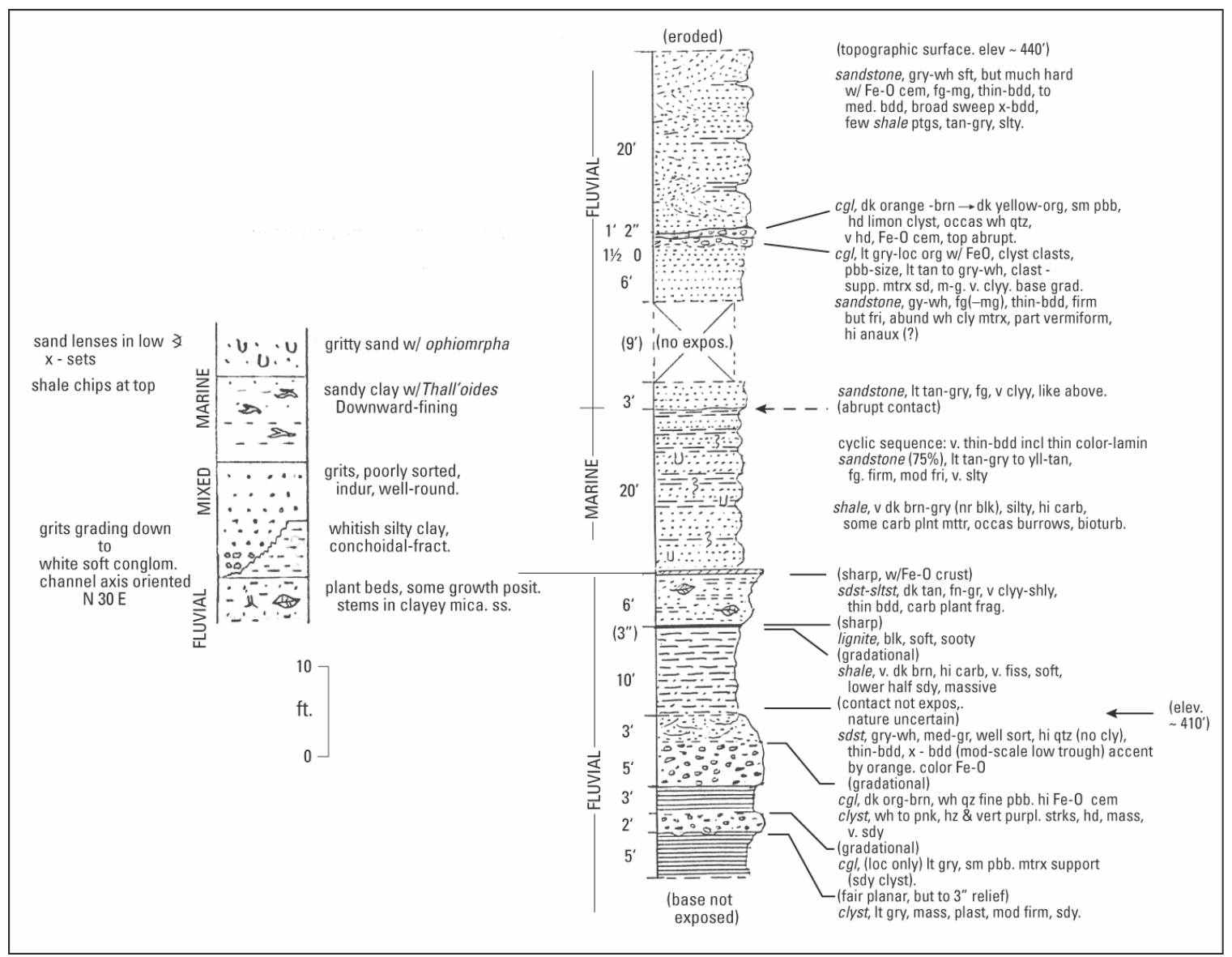

Figure 19B. Composite section and correlation of sections from Newman pit, powerline and railroad (eastern basin between Ione and highway 88), showing marine and non-marine facies. 


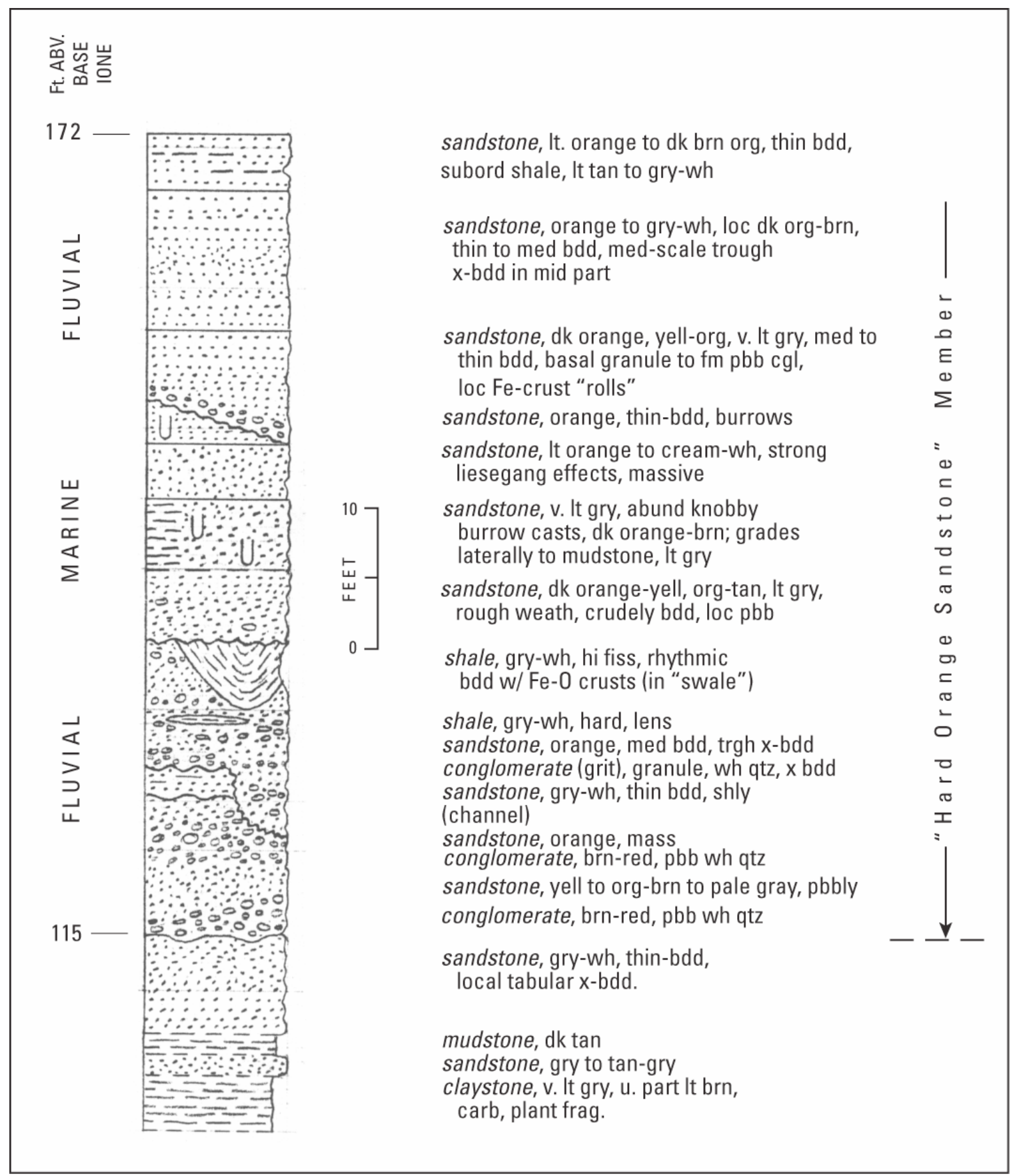

Figure 19C. Measured section of Ione Formation along state highway 88 , showing marine and non-marine facies. 


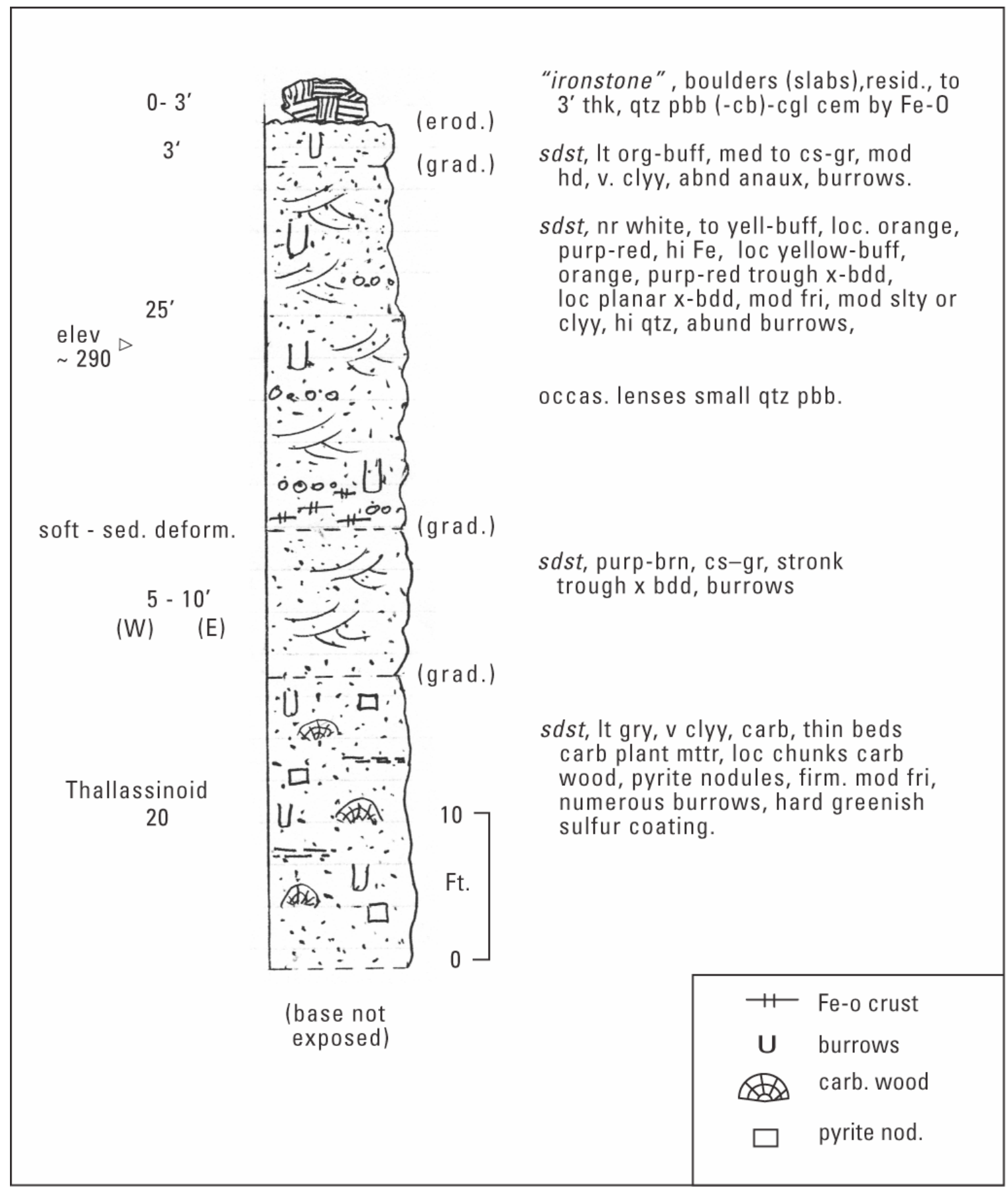

Figure 19D. Approximate sections in 273 (Triangle) pit, showing distribution of Ophiomorpha and other burrows. 


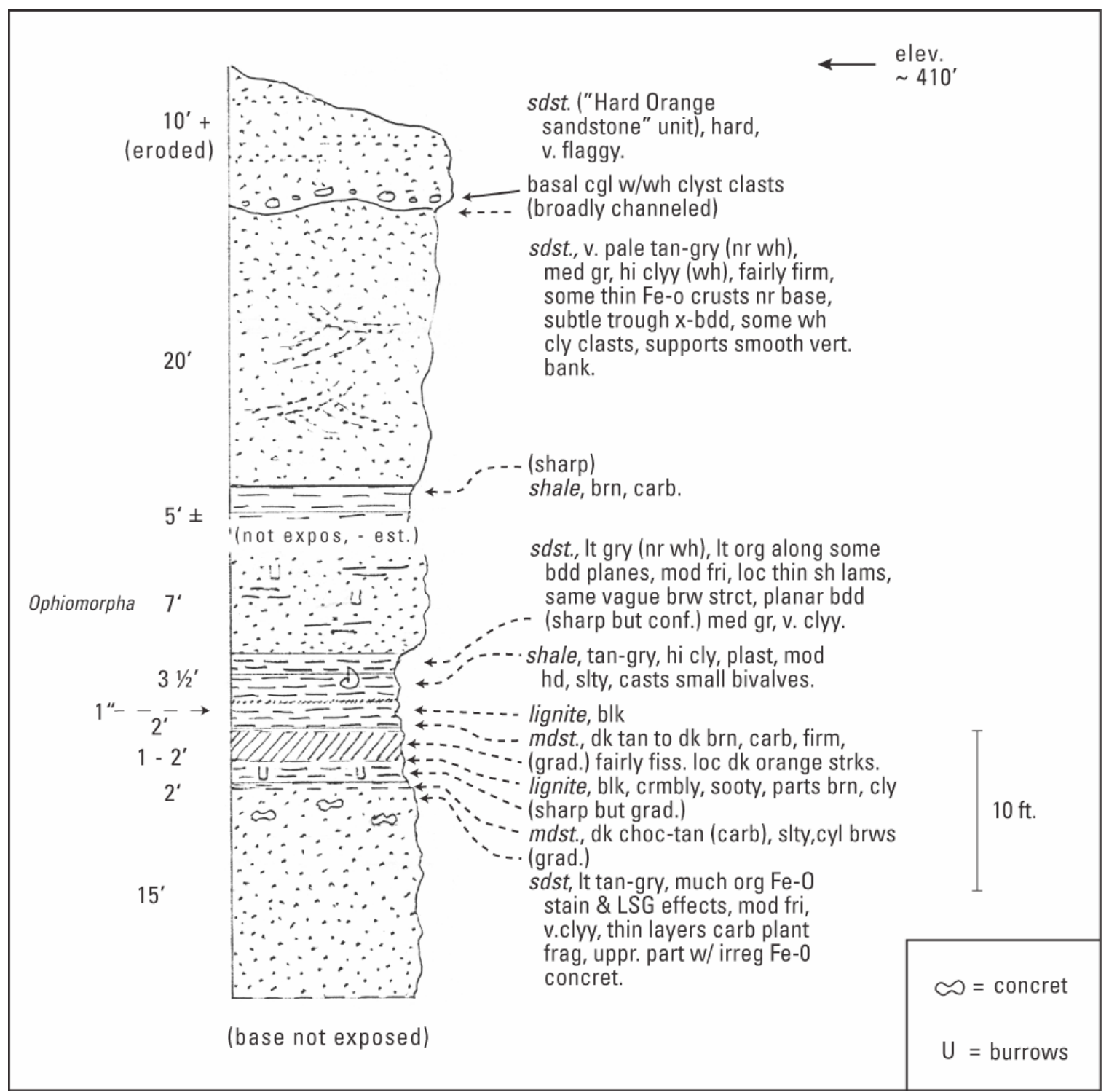

Figure 19E. Approximate section along west face of "SE pit", showing distribution of Ophiomorpha and bivalve identified as Nuculana, close to gabbii. 


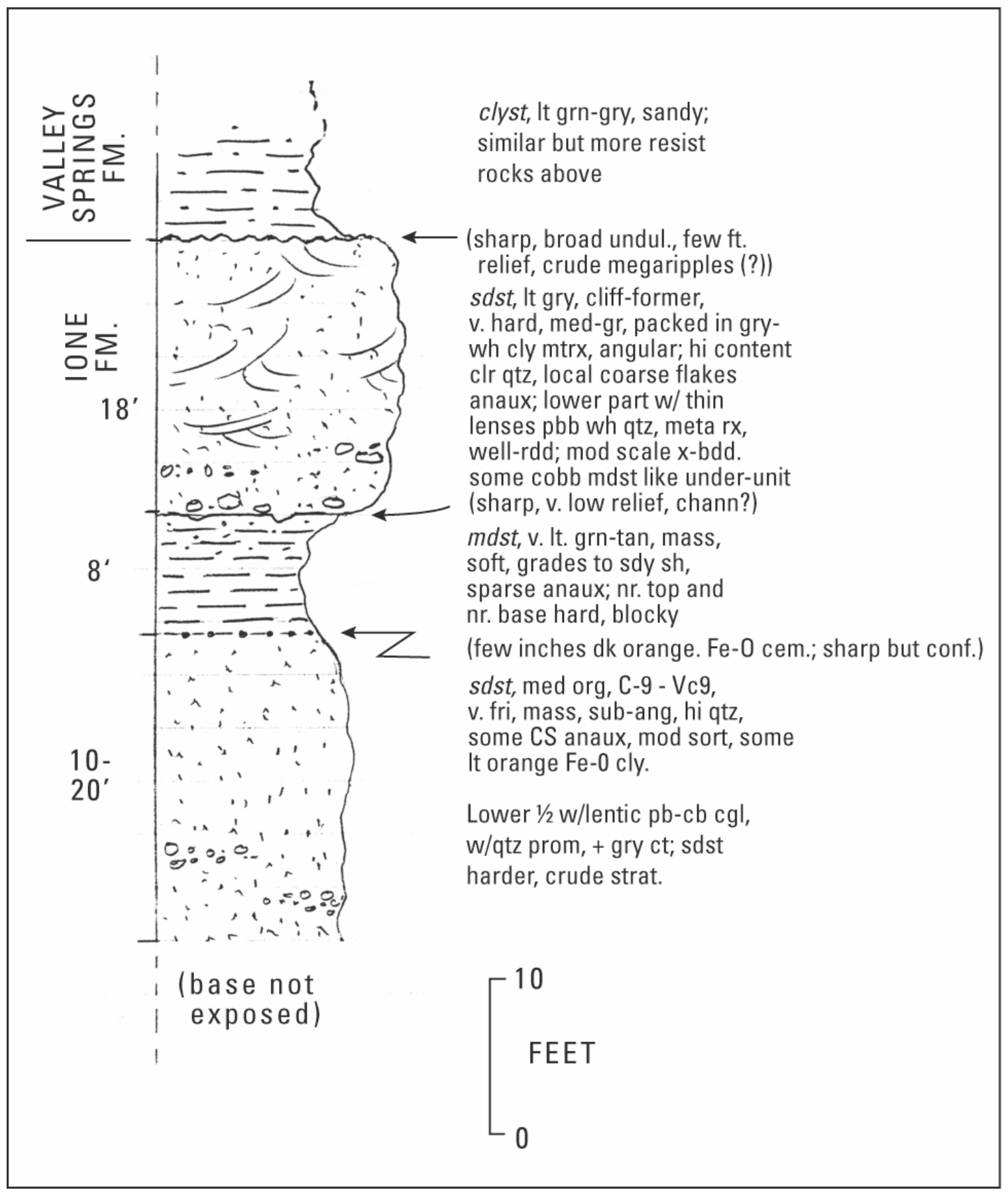

Figure 19F. Approximate section at "Sugarloaf" (Lake Camanche, south shore). 


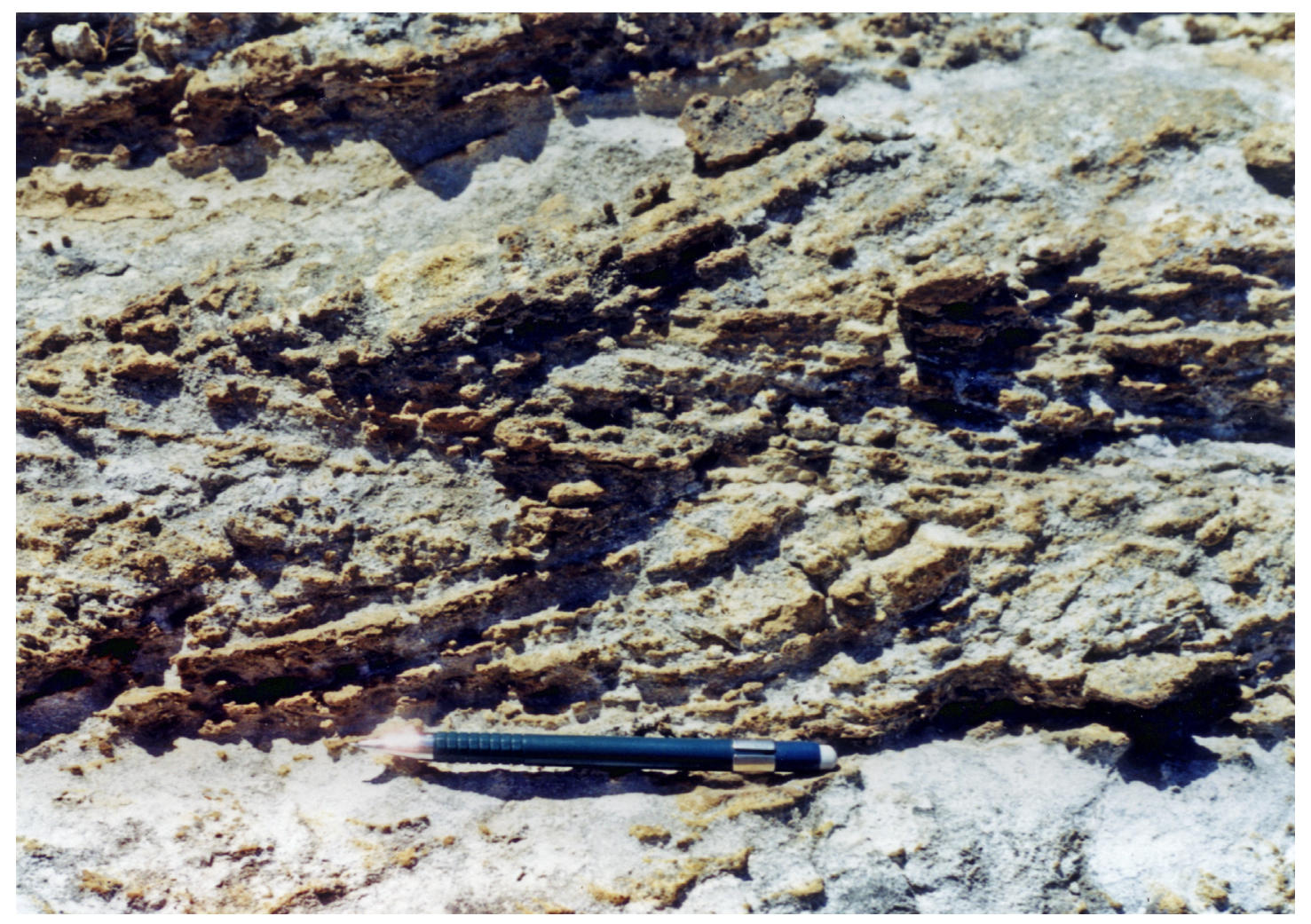

Figure 20. "Herringbone" cross-bedding in "hard orange sandstone", roadcut on state highway 88.

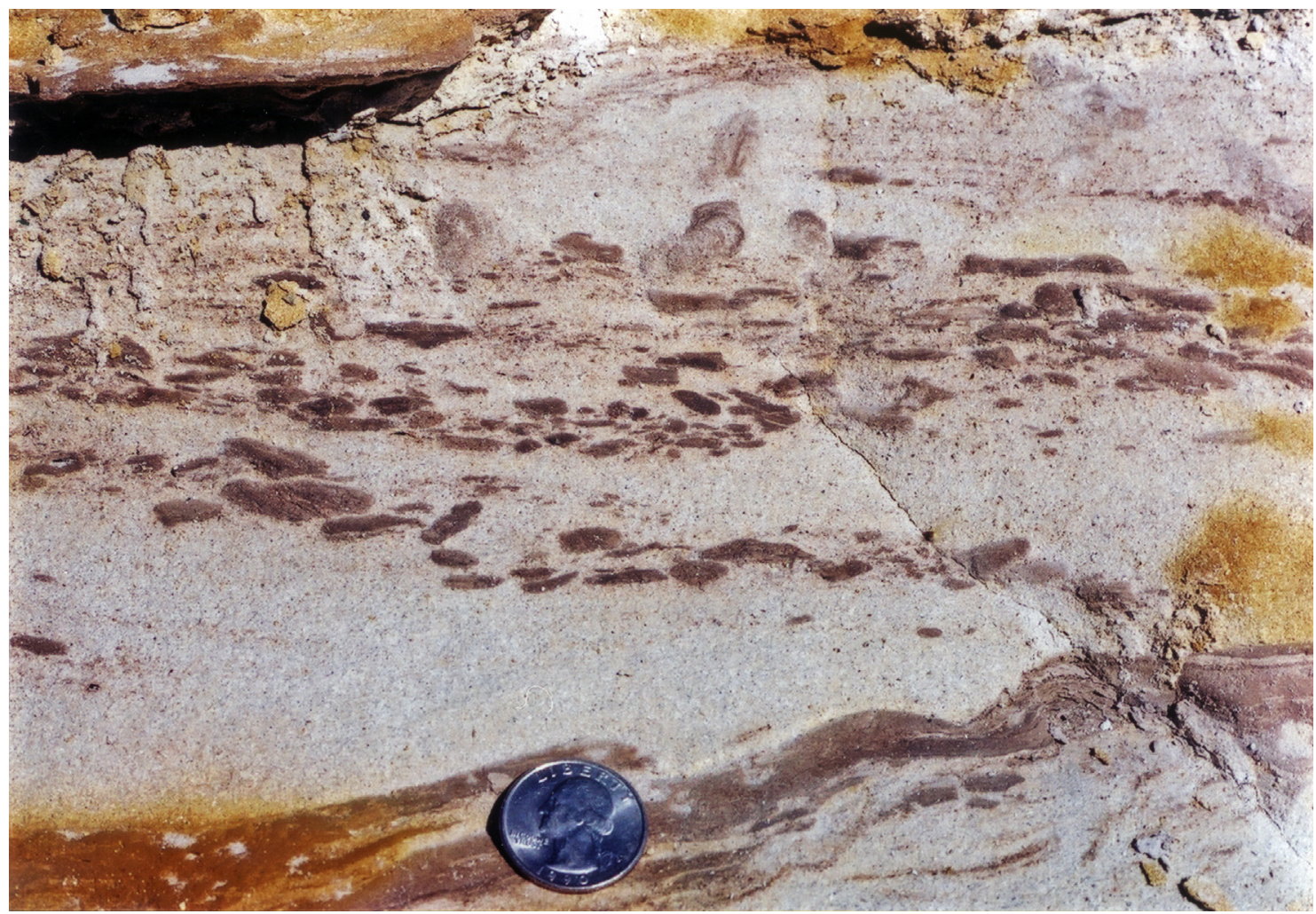

Figure 21. Clay drapes and rip-up clasts in sandstone (coin is $24 \mathrm{~mm}$ in diameter), lower part of Ione Formation, state route $205,1 \mathrm{~km}$ south of Ione. 


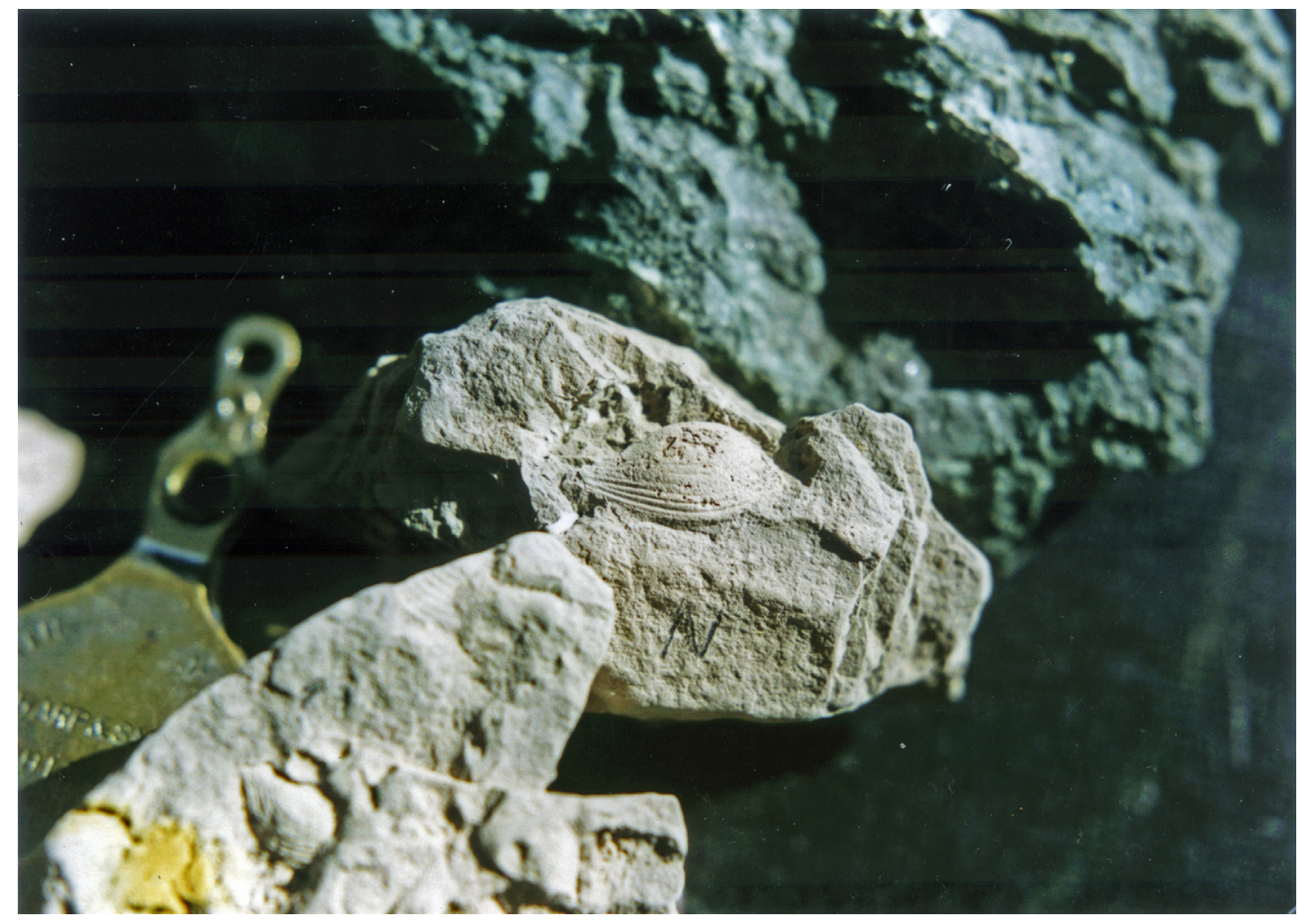

Figure 22. Cast of Nuculana (?) in blocky tan mudstone near former calcining plant \#2 (fig. 8). Scale bar approximately $1 \mathrm{~cm}$.

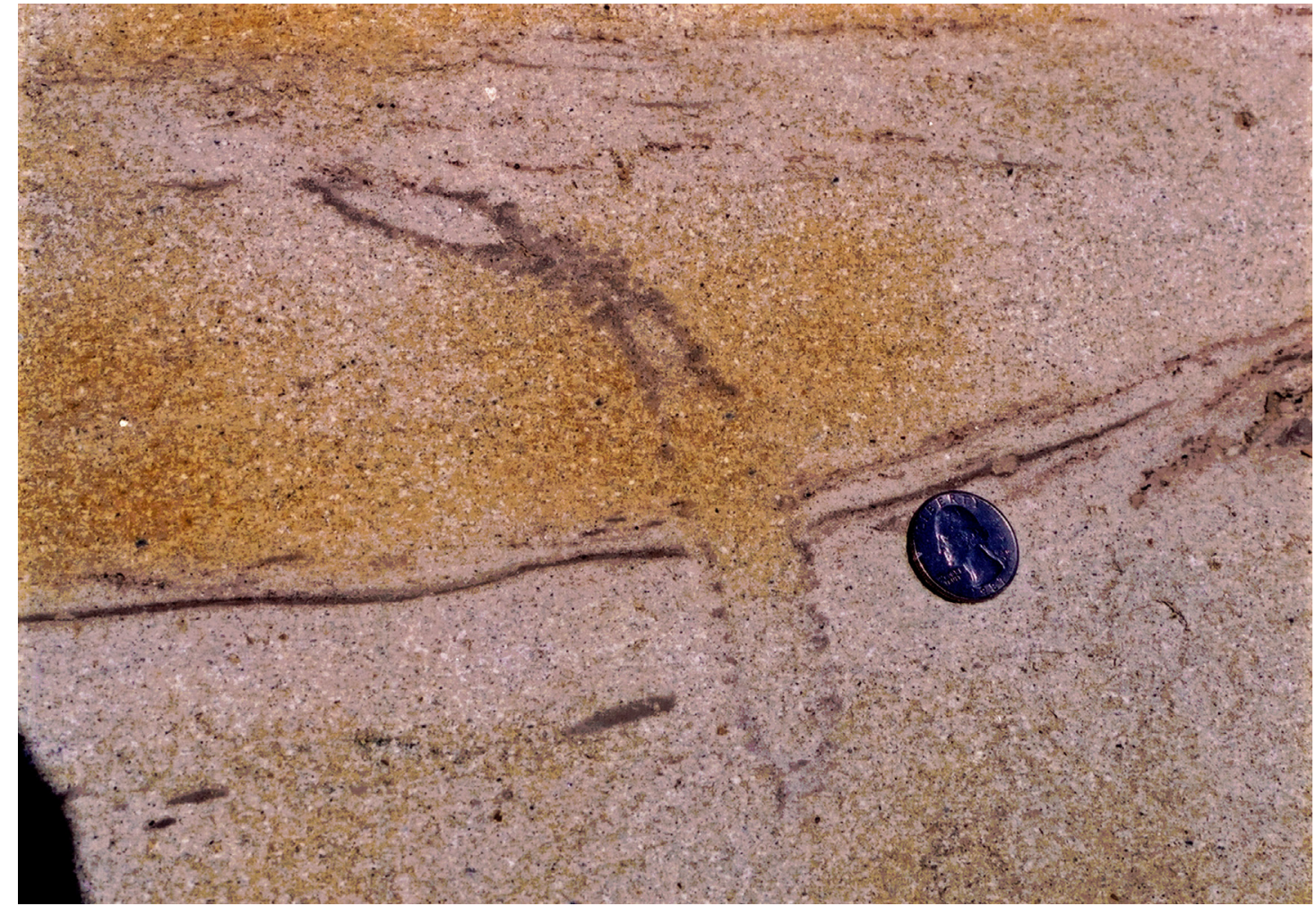

Figure 23. Ophiomorpha burrow lined with dark clay showing knobby structure in sandstone (coin is 24 $\mathrm{mm}$ in diameter). Roadcut on Camanche Parkway North. 


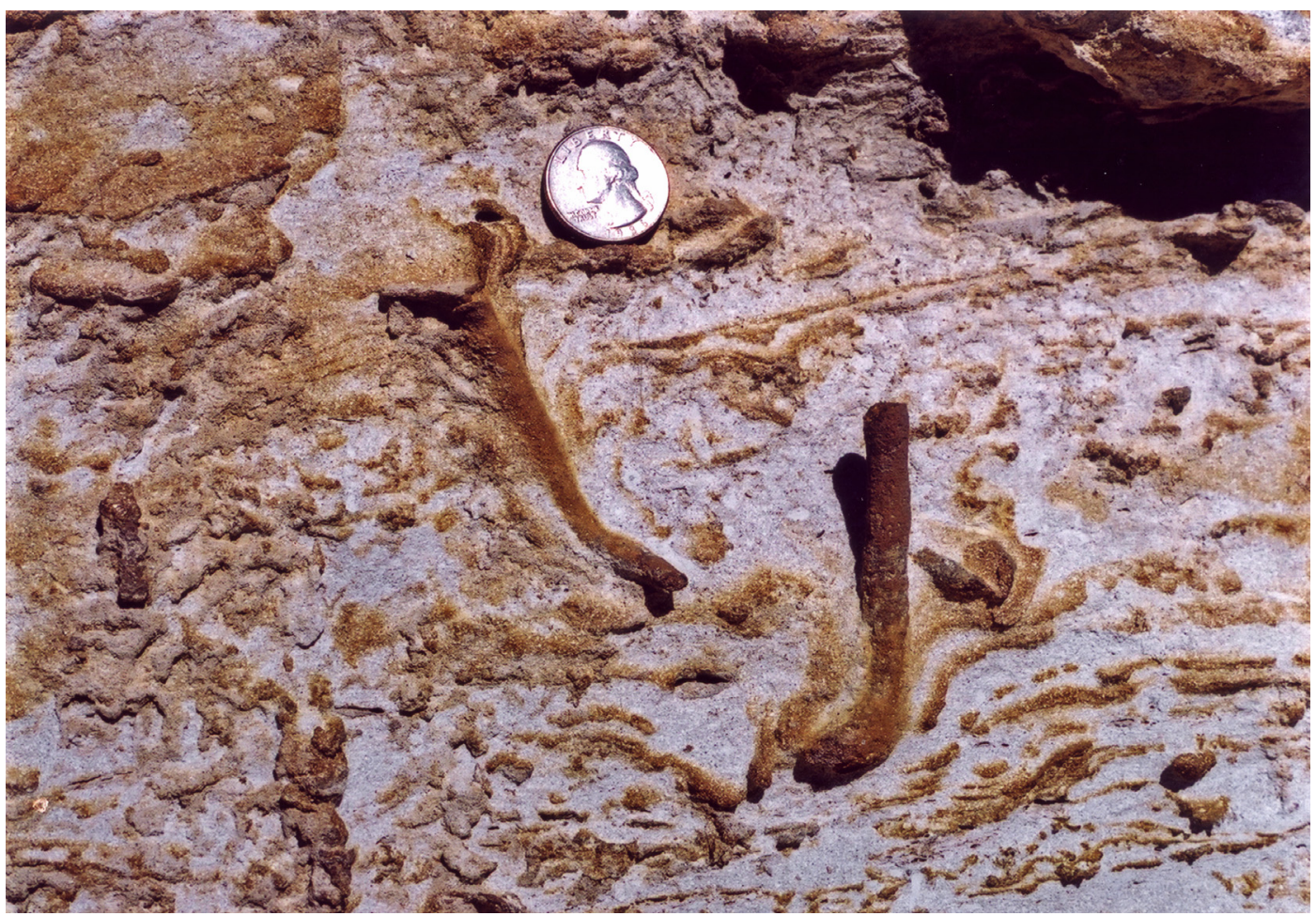

Figure 24. Interior casts of Ophiomorpha burrows preserved as iron-oxide-cemented sand (thus more resistant than surrounding lighter-colored sand; coin is $24 \mathrm{~mm}$ in diameter), "Hard orange sandstone" along state route 88 .

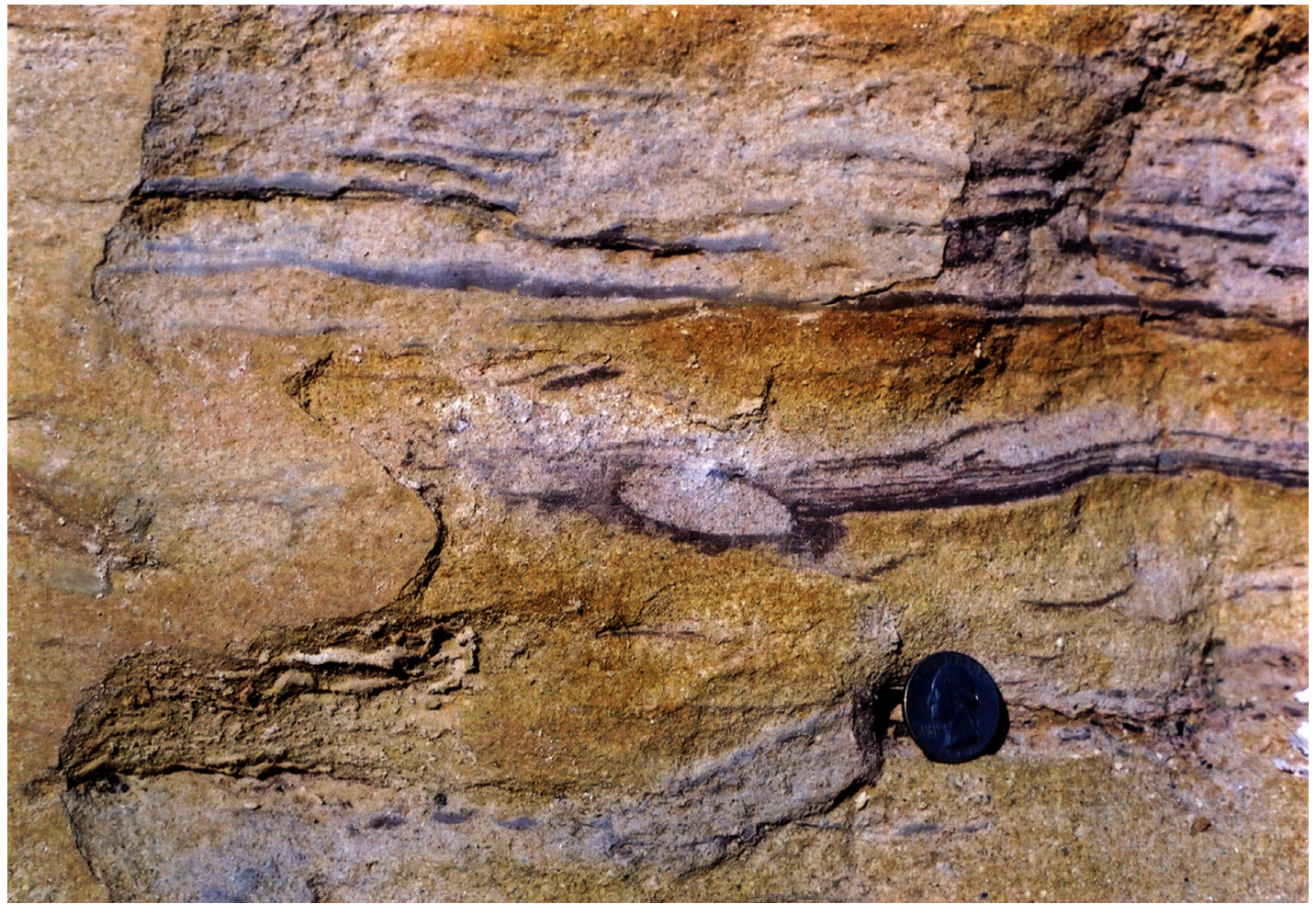

Figure 25. Ophiomorpha burrow with knobby structure within bedding of dark clay parting in sandstone. Clay rip-ups in upper part of photo (coin is $24 \mathrm{~mm}$ in diameter). Camanche Parkway North. 


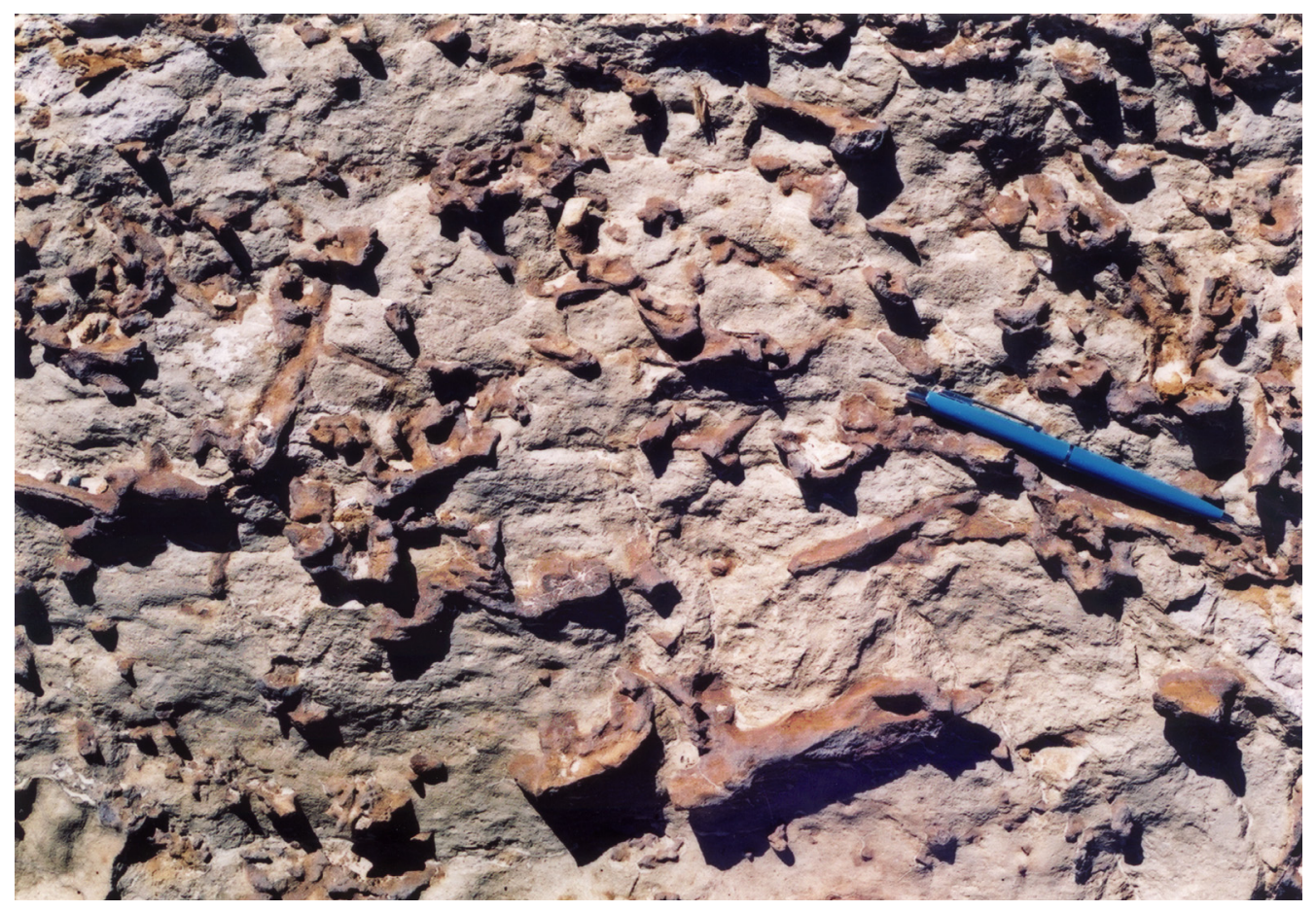

Figure 26. Thalassinoides (?) burrows in massive gray sandy mudstone. Casts are Fe-O-rich, thus harder than host. (Pen is $13.5 \mathrm{~cm}$ long). "Hard orange sandstone", roadcut along route 88 (fig. 27, unit B).

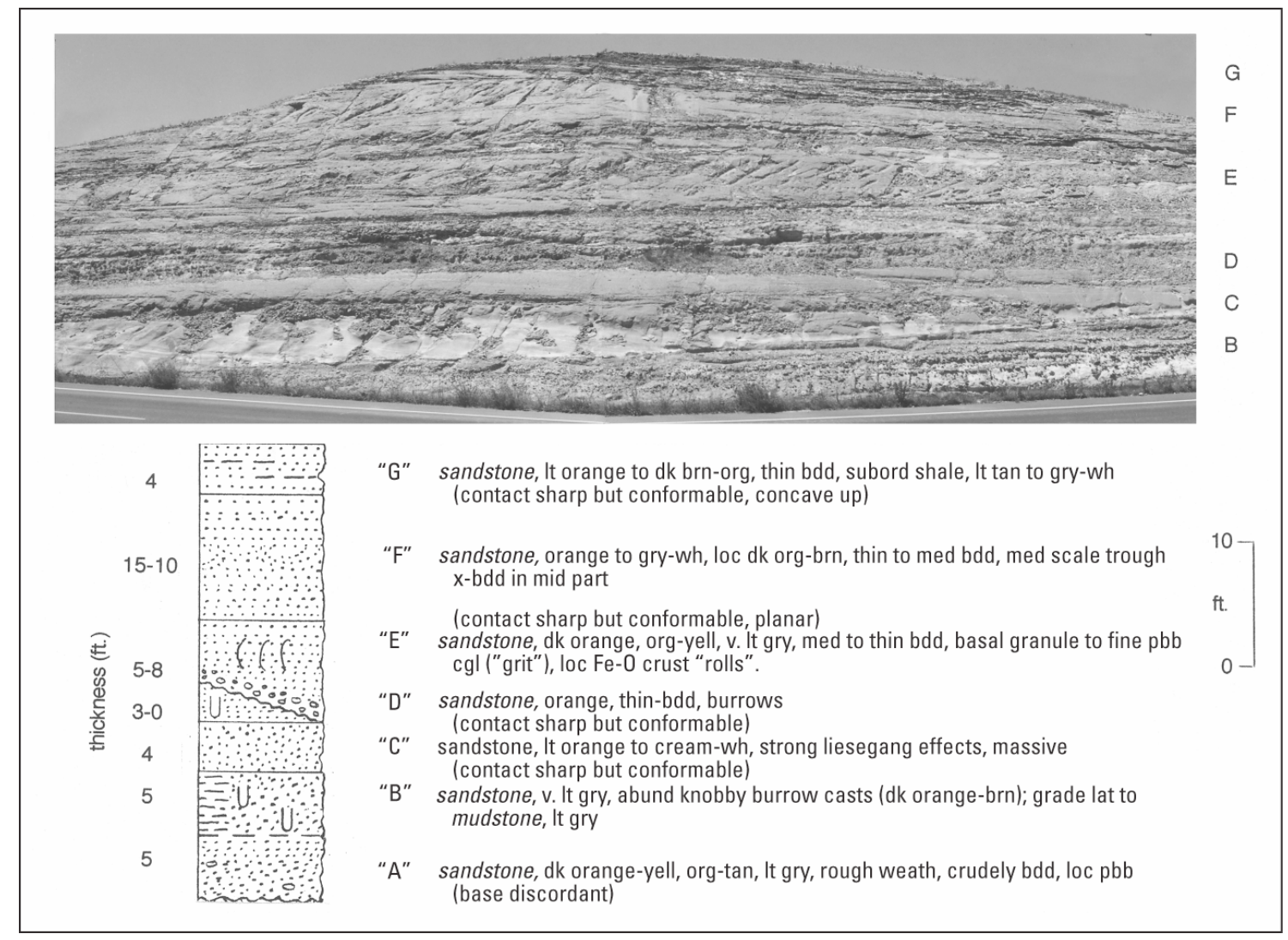

Figure 27. Relations of transitional-marine sand bodies in partial section of "hard orange sandstone" exposed in roadcut along state highway 88, about $2 \mathrm{mi}$. (3 km) SSE of Ione and $0.6 \mathrm{mi}(1 \mathrm{~km})$ east of IoneBuena Vista Road, shown both in stratigraphic-section and photo form. Unit " $A$ " not present in this cut. 


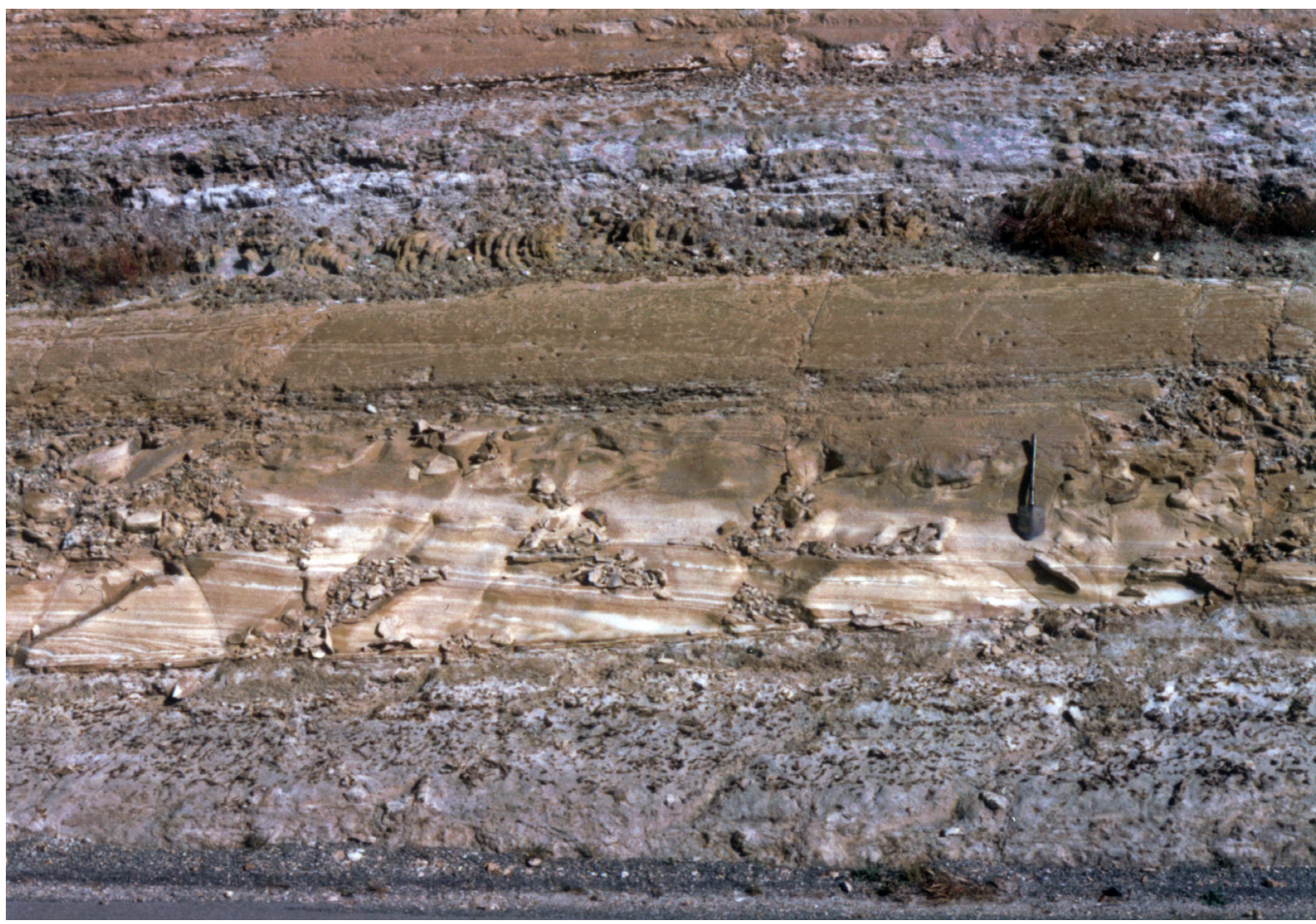

Figure 28. Detail of figure 27 showing contact of muddy (lagoonal?) sandstone of unit B below and (shoreline?) sandstone of unit $\mathrm{C}$ above arrows. Shovel (right) is $2 \mathrm{ft}$. long. Roadcut on state highway 88.

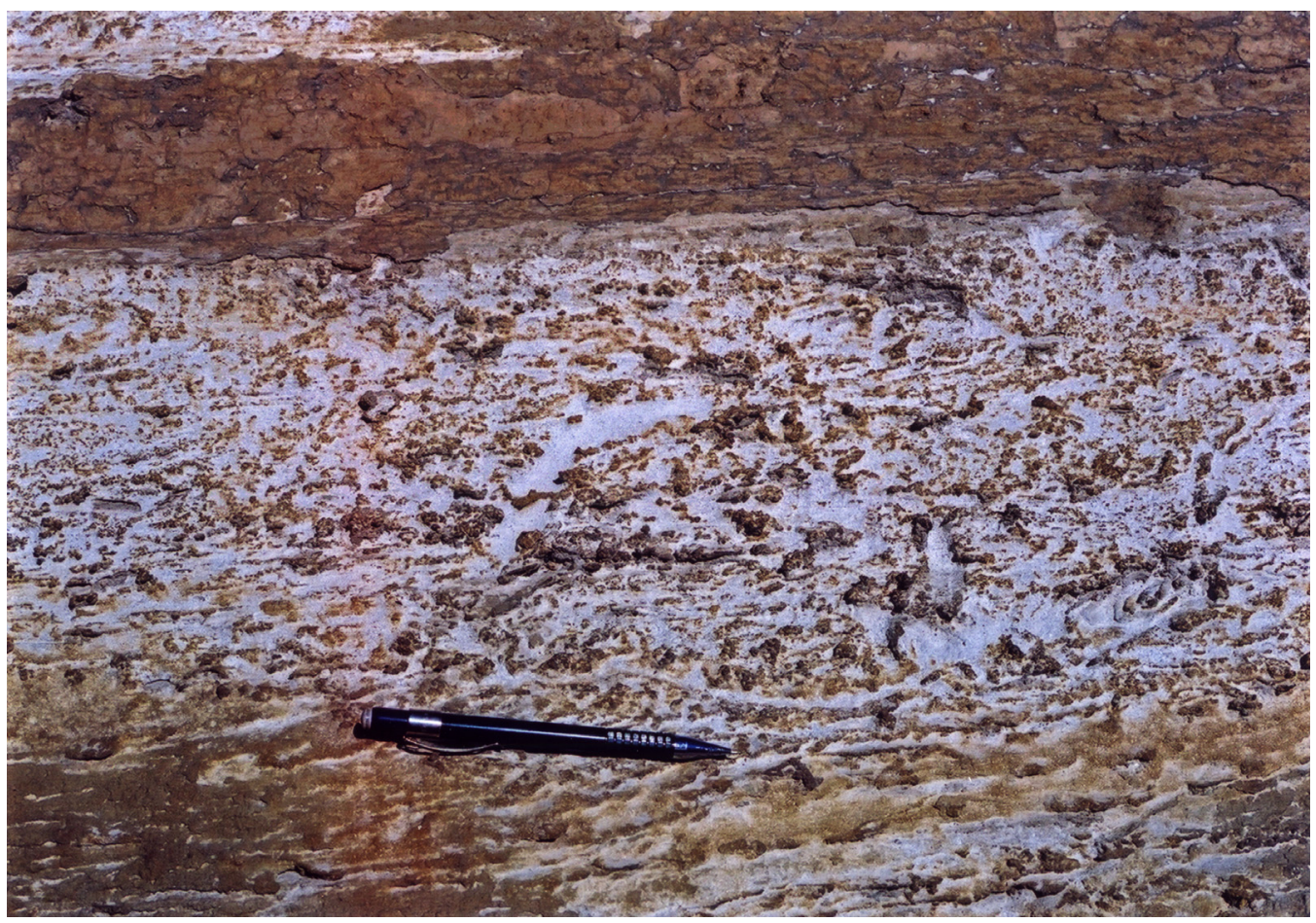

Figure 29. Bioturbated ("scrappy") sandstone with disruption of Fe-O-hardened layers (pencil is $13.5 \mathrm{~cm}$ long), "Hard orange sandstone," state highway 88. 


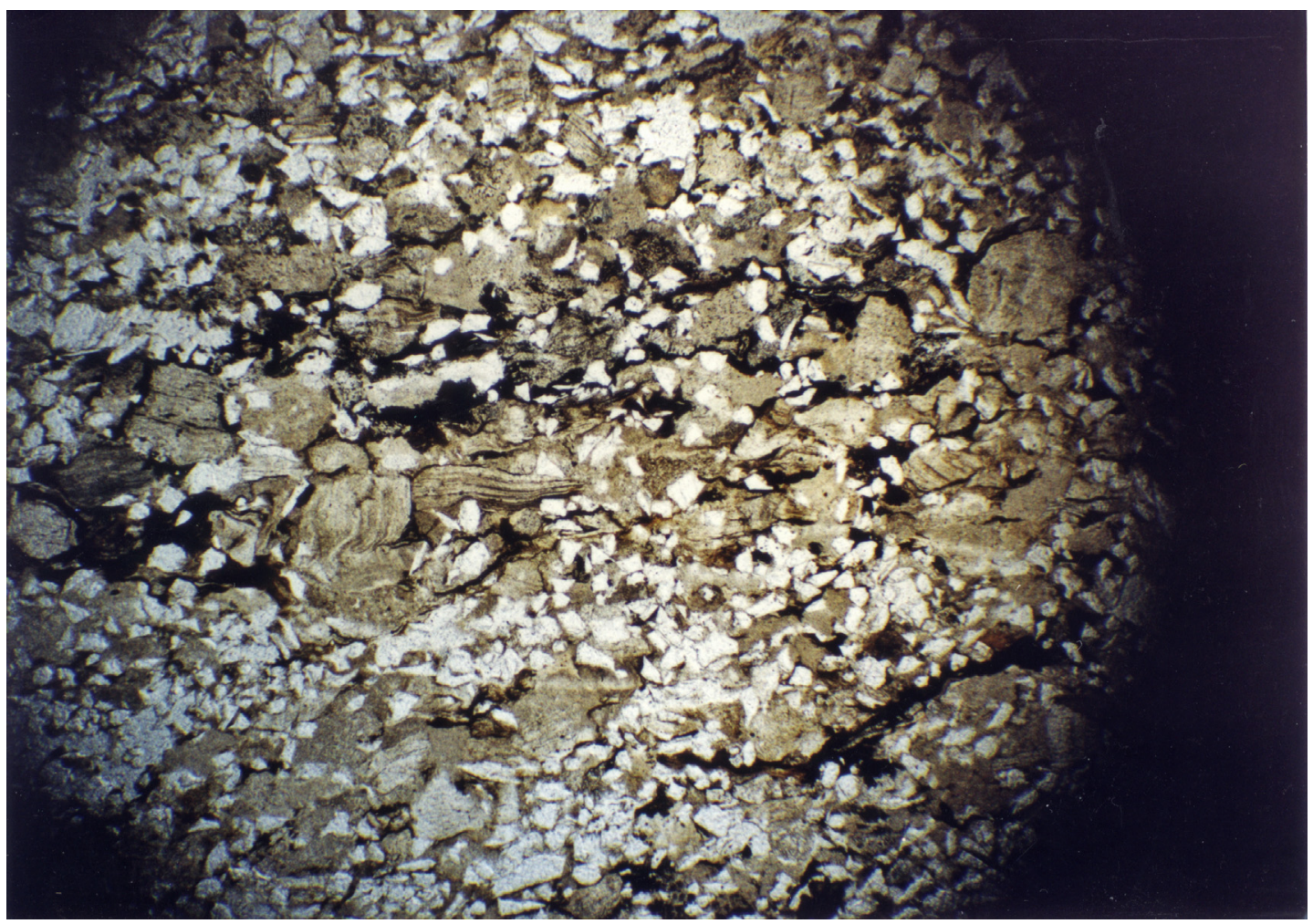

Figure 30. Photomicrographs of Ione-Formation rocks: A. Fine-grained sandstone with lamina of "anauxite" clasts, Waters Peak (sample Io 26)

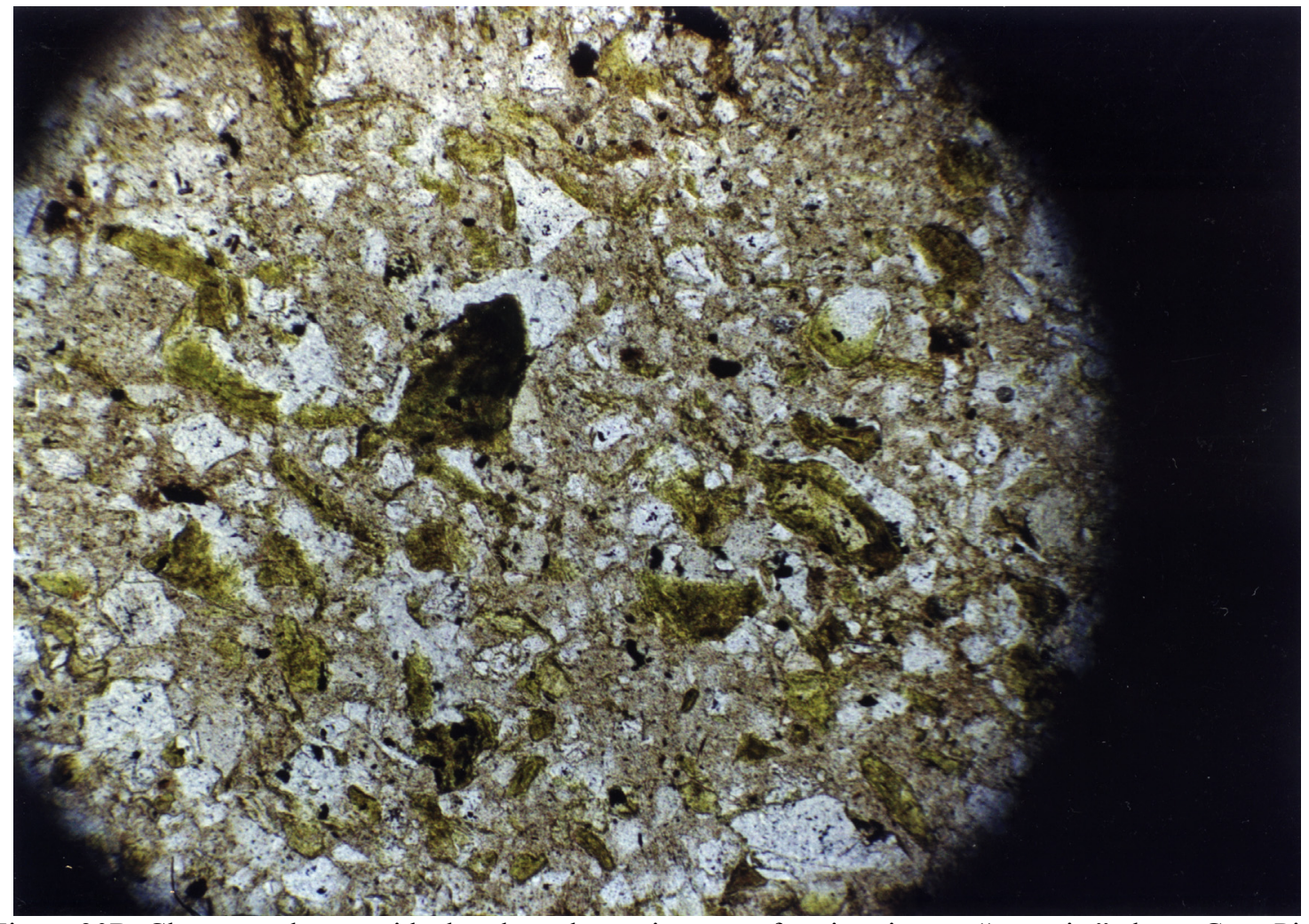

Figure 30B. Clayey sandstone with abundant glauconite, some forming rims on "anauxite" clasts, Gage Pit (sample 89-3-26) 


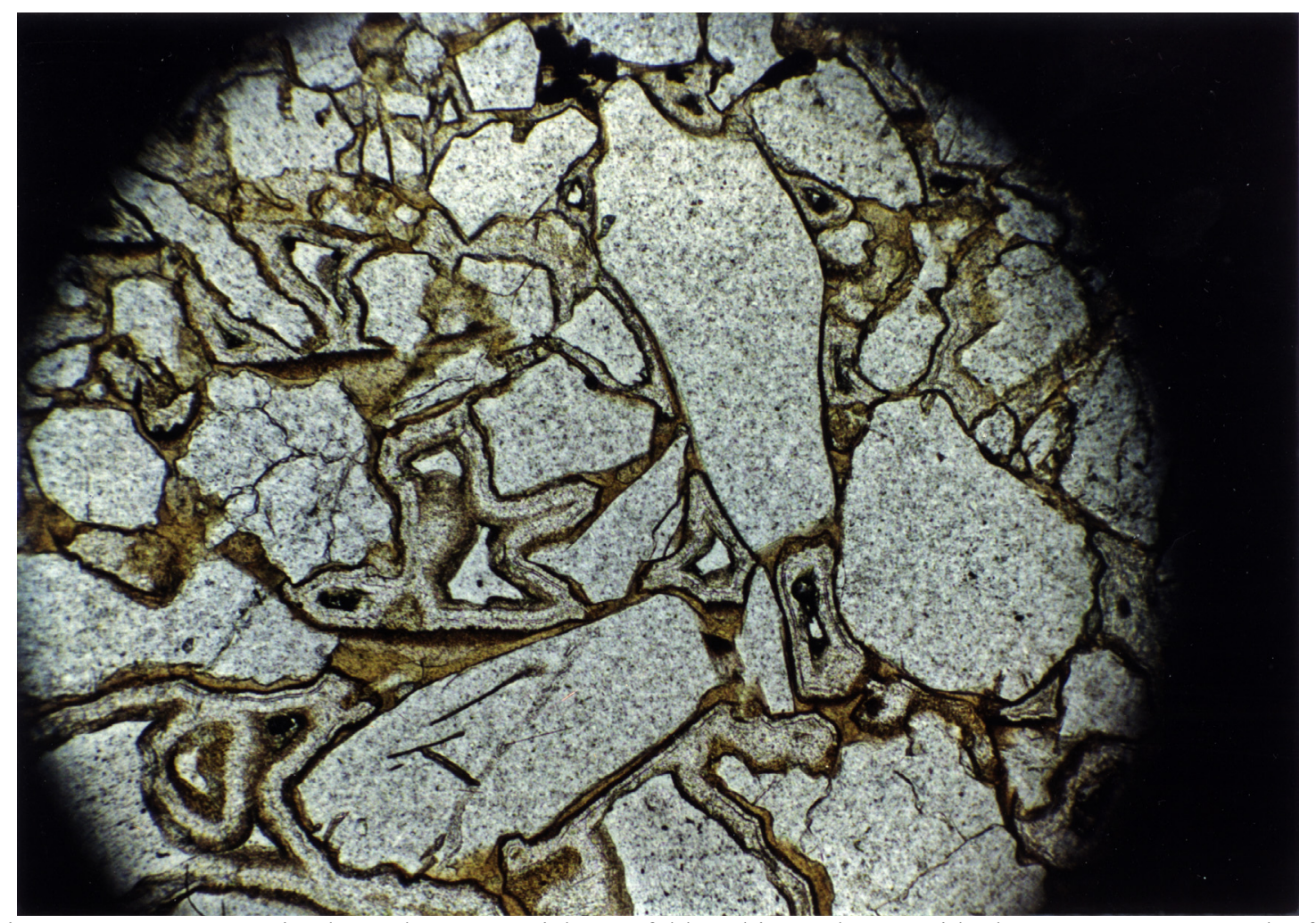

Figure 30C. Coarse-grained angular quartz-rich non-feldspathic sandstone with clay cement, mesa north of Carbondale (sample Io 62)

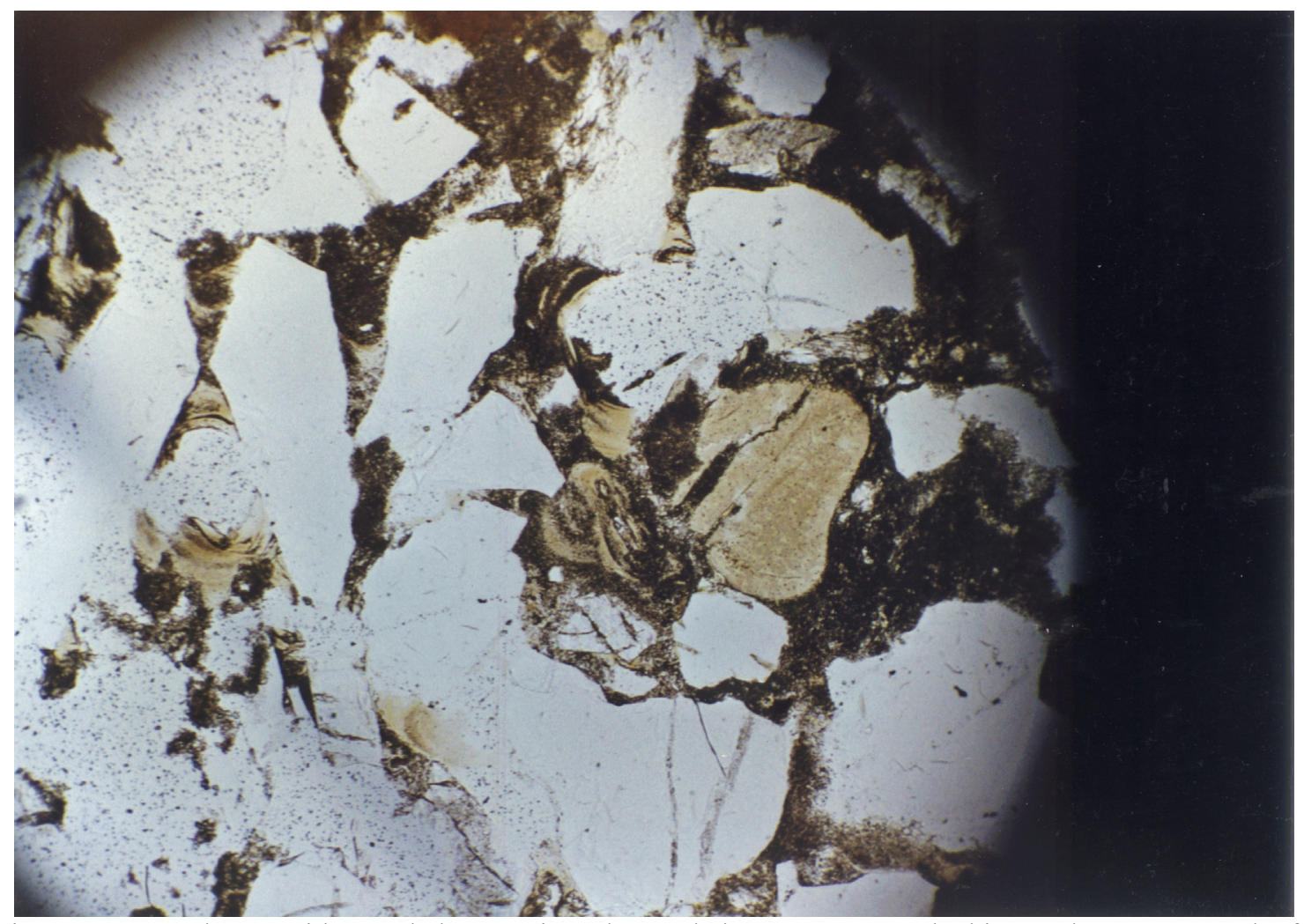

Figure 30D. Sandstone with rounded "anauxite" clast and clay cement. Hard white sandstone at Sugarloaf, Lake Camanche (sample 89-3-21) 


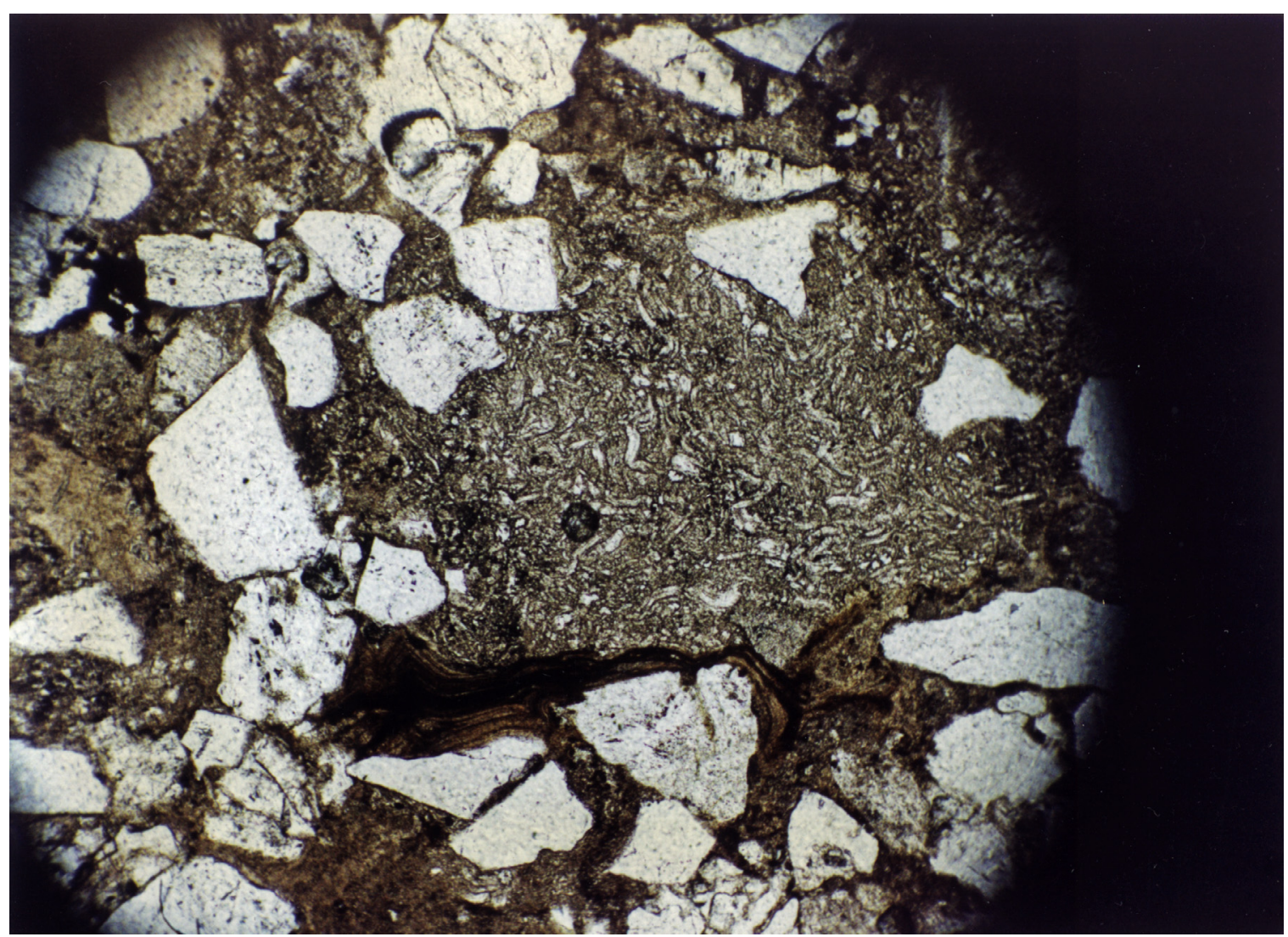

Figure 30E. Vermiform "micro-anauxite" in clay clast. Lowest part of hard white sandstone in Lancha Plana measured section (sample 89-3-19). All above: field diameter 3mm, plane-polarized light

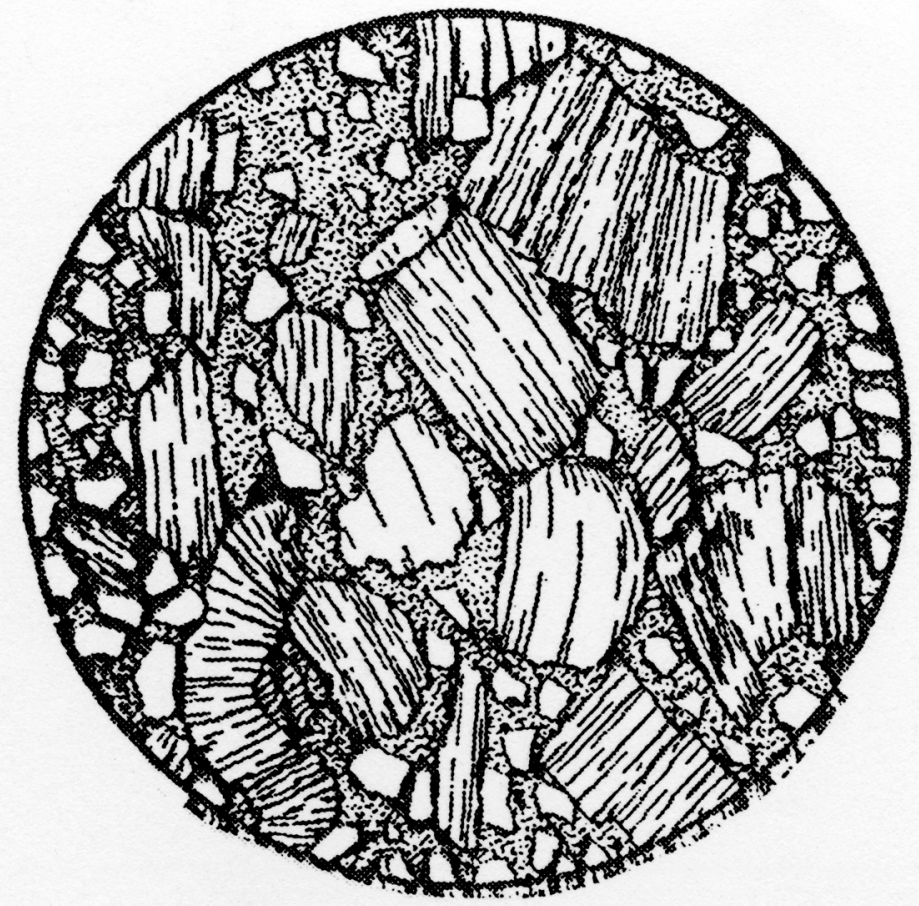

Figure 30F. Diagram of "authigenic kaolinite (3mm field diameter), fig. 12-2A of Williams, Turner, and Gilbert (1982) "Eocene of Ione California" 


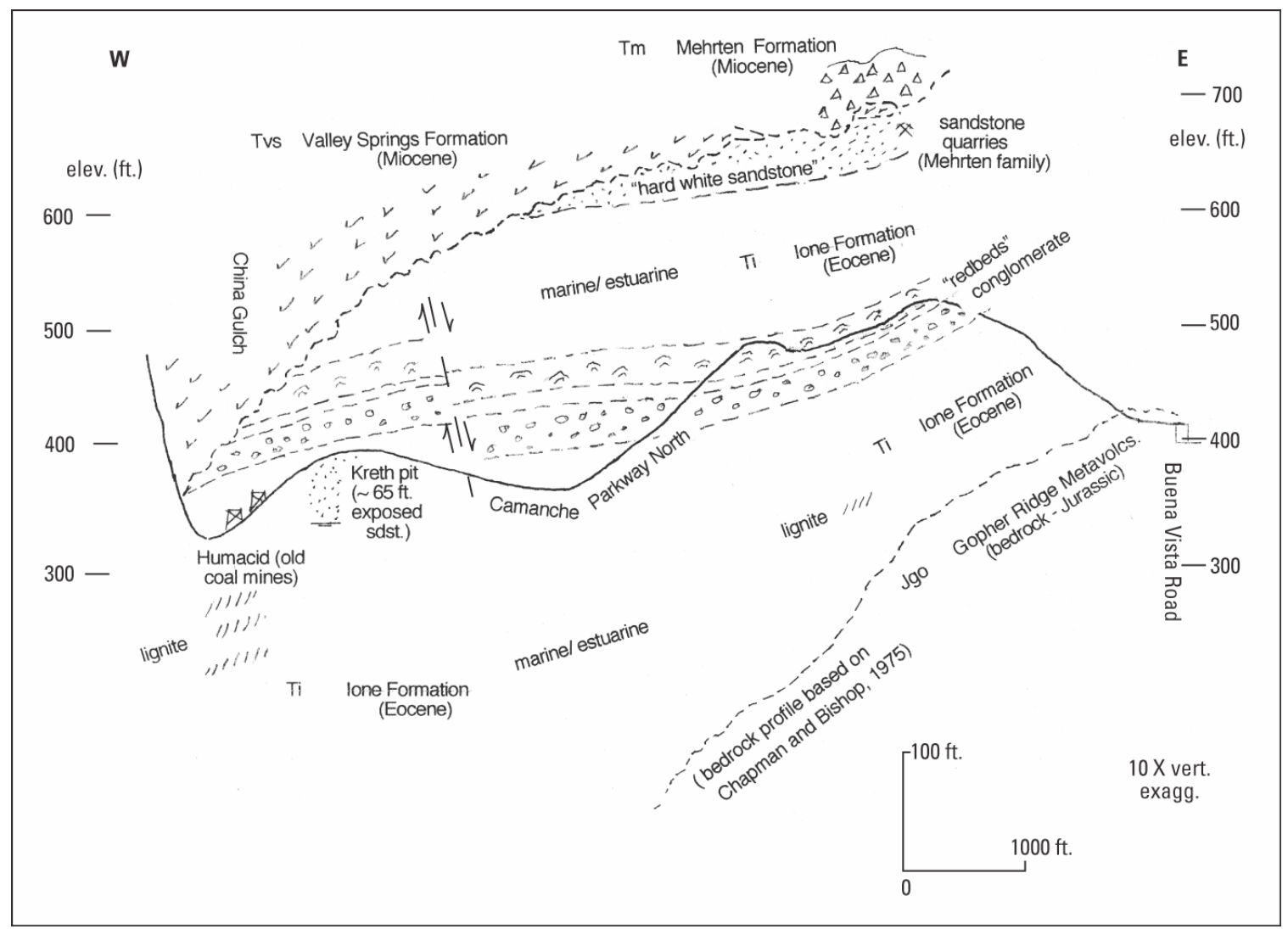

Figure 31. Structure sections through Ione Formation oriented generally east-west: A. Schematic structure section as a projection onto an E-W vertical plane in the vicinity of Camanche Parkway North/China Gulch;

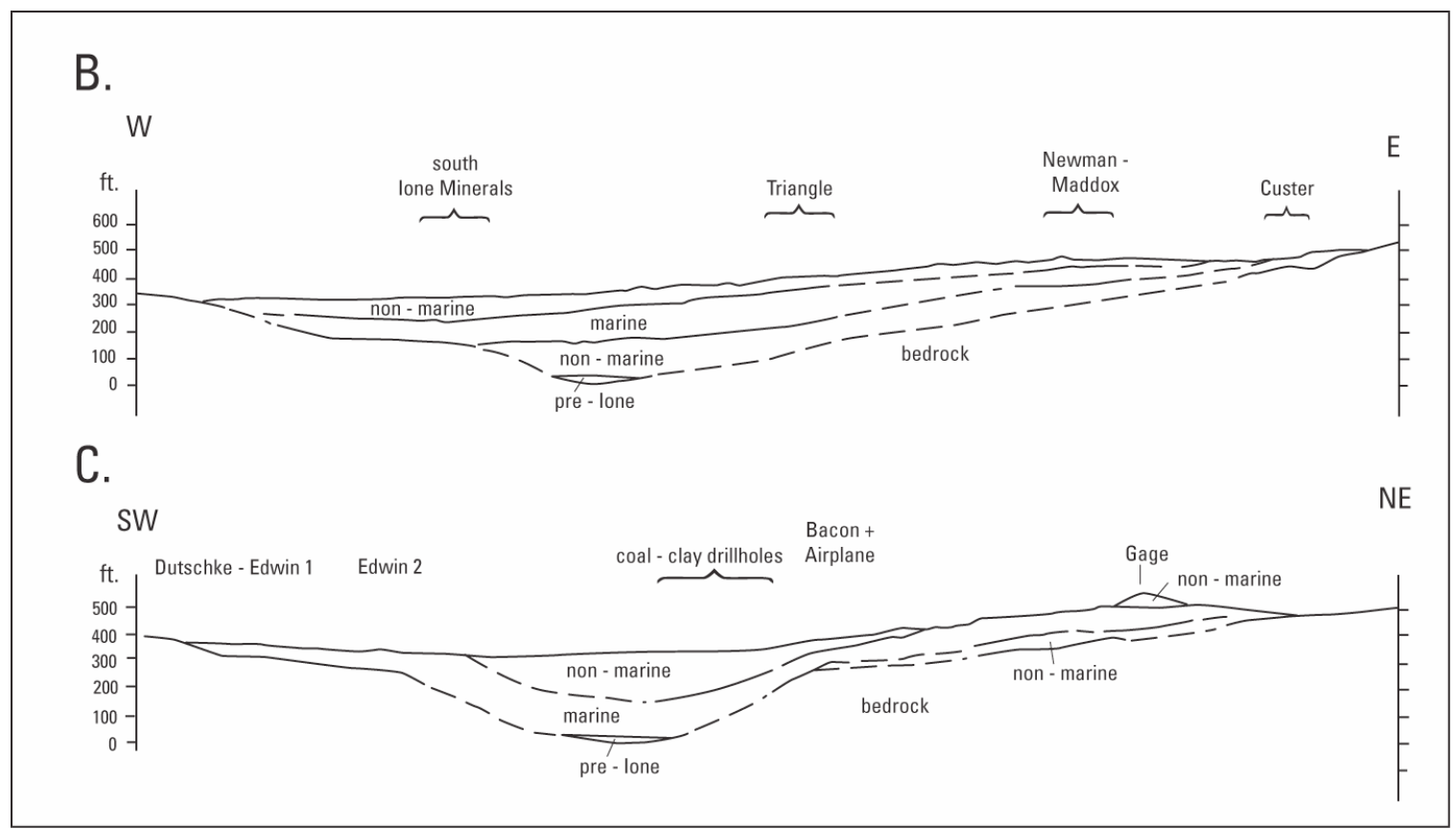

Figure 31B. Section through Custer, Newman-Muddox, Triangle, and southern Ione Minerals pits; C.

Section through Gage, Bacon-Airplane, and Dutschke pits. Localities from figure 8. Intervals of marine influence are shown (based on Ophiomorpha, other fossils, and glauconite) overlain and underlain by nonmarine deposits (based on coals and coarse gravels). Deposits below sea-level are apparently pre-Ione 
(from Chapman and Bishop, 1975, a source also for bedrock contact). Points of control from pits and drillholes shown above section. Coal-clay drillholes from Johnson and Ricker (1948); control near Ione Minerals from Gillam (1974).

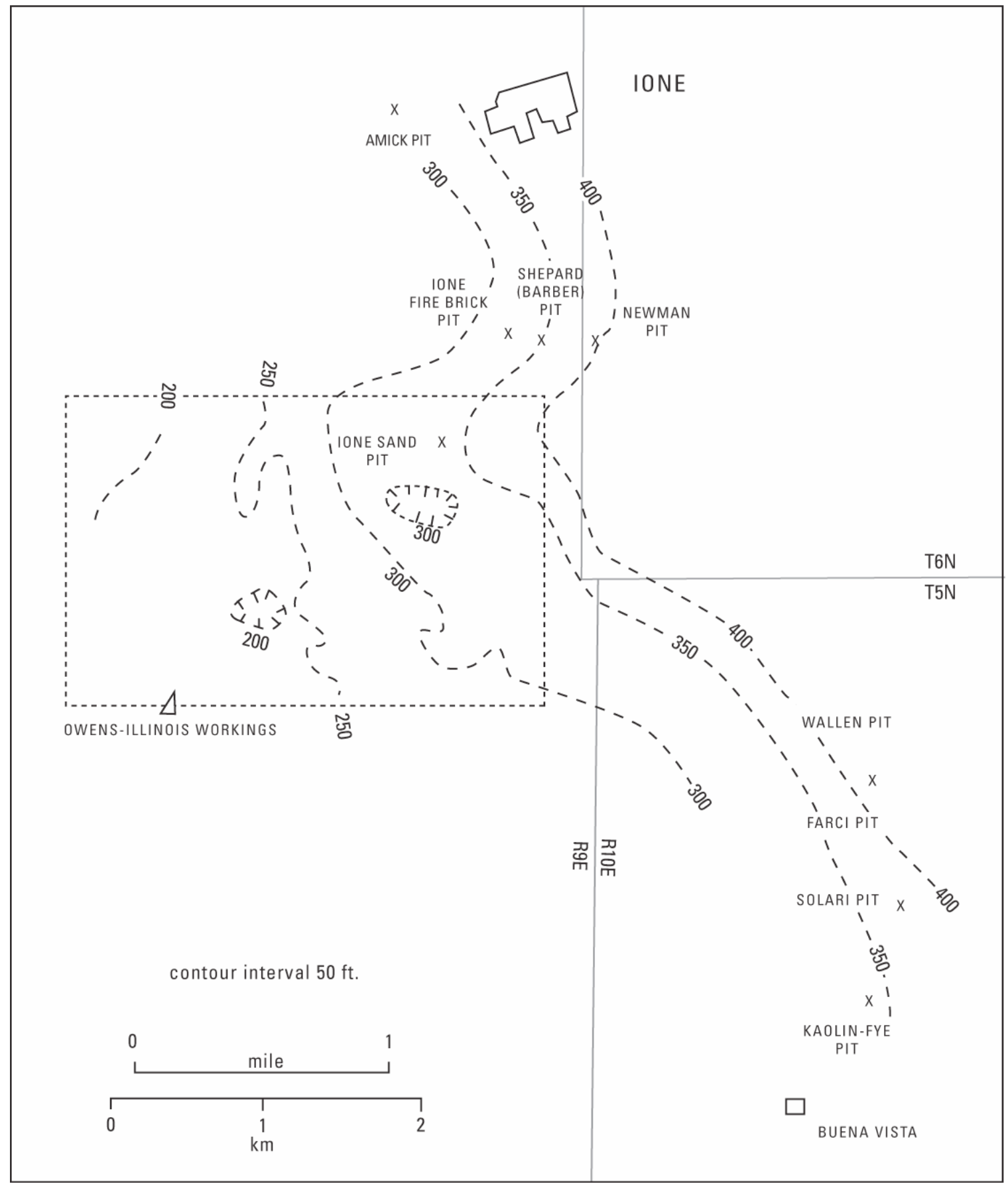

Figure 32. Distribution of Ione Sand member. Named pits are those in which this unit serves or did serve as principal "pay." Also shown are structural contours on top of Ione sand. Dotted outline denotes area drilled and mined by Owens-Illinois (see fig. 33). 


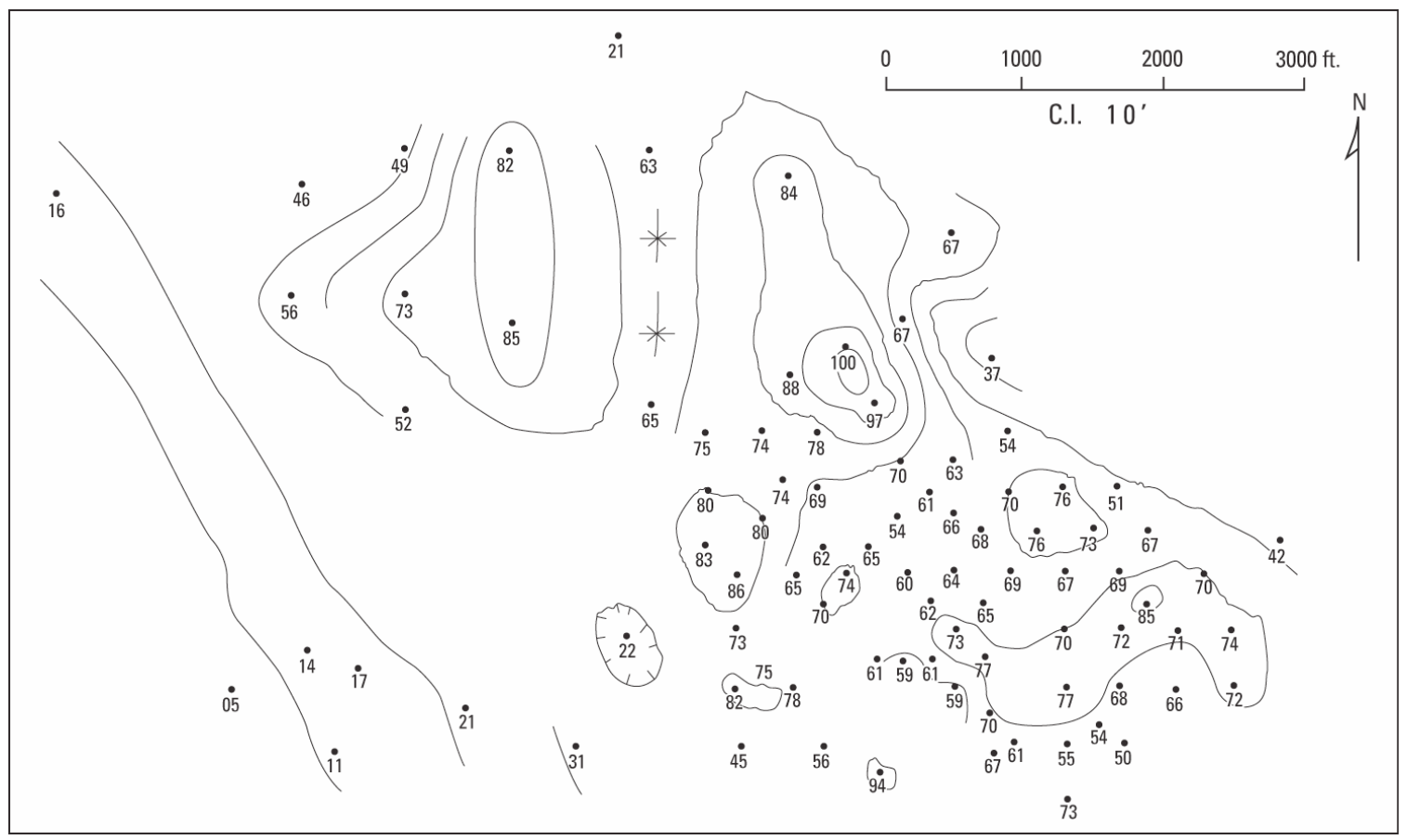

Figure 33. Thickness of Ione sand in Owens-Illinois pit (data from Gillam, 1974).

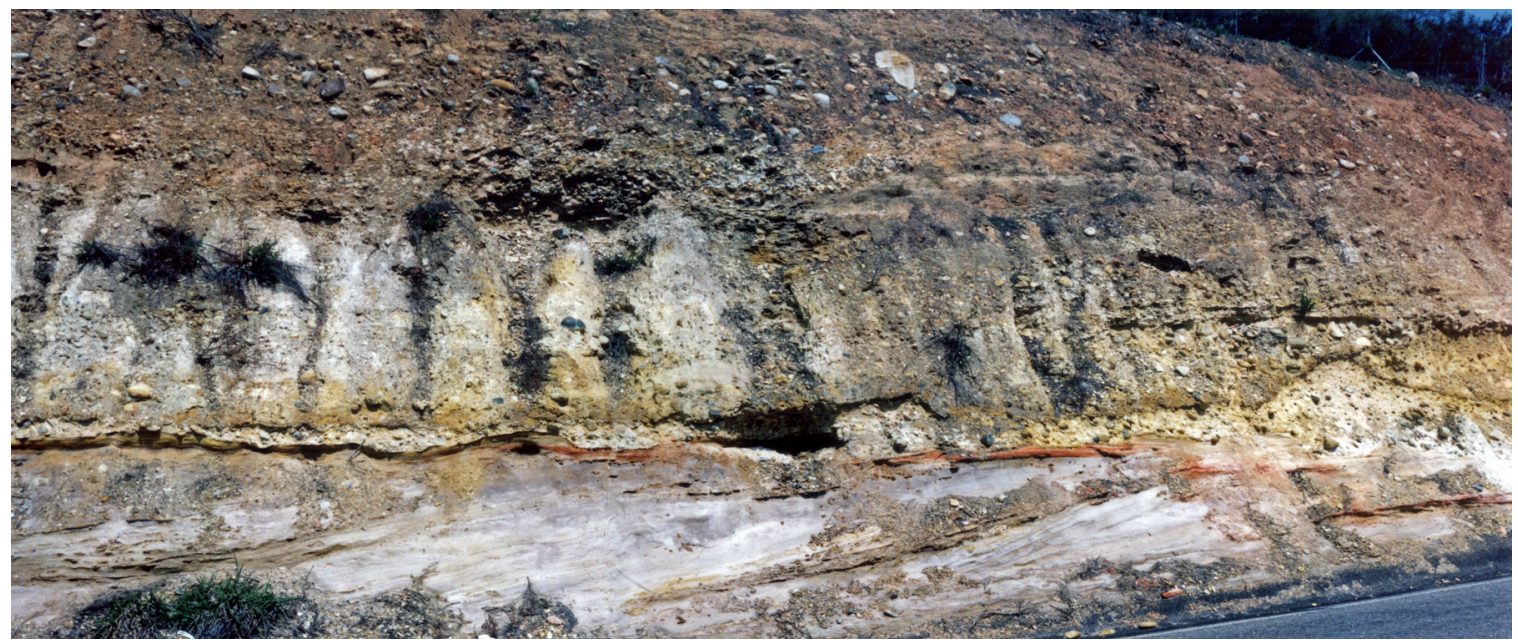

Figure 34. Irregular contact (between arrows) of shallow marine or estuarine deposits overlain by nonmarine (fluvial) sandstone and conglomerate. Lower beds with low-angle cross-stratification probably represent an intertidal sand flat, followed by a basinward progradation. Scale bar is $4 \mathrm{ft}$. long. Roadcut on Camanche Parkway North, about $2 \mathrm{~km}$ west of junction with Ione-Buena Vista Road, China Gulch area: A. Whole outcrop; 


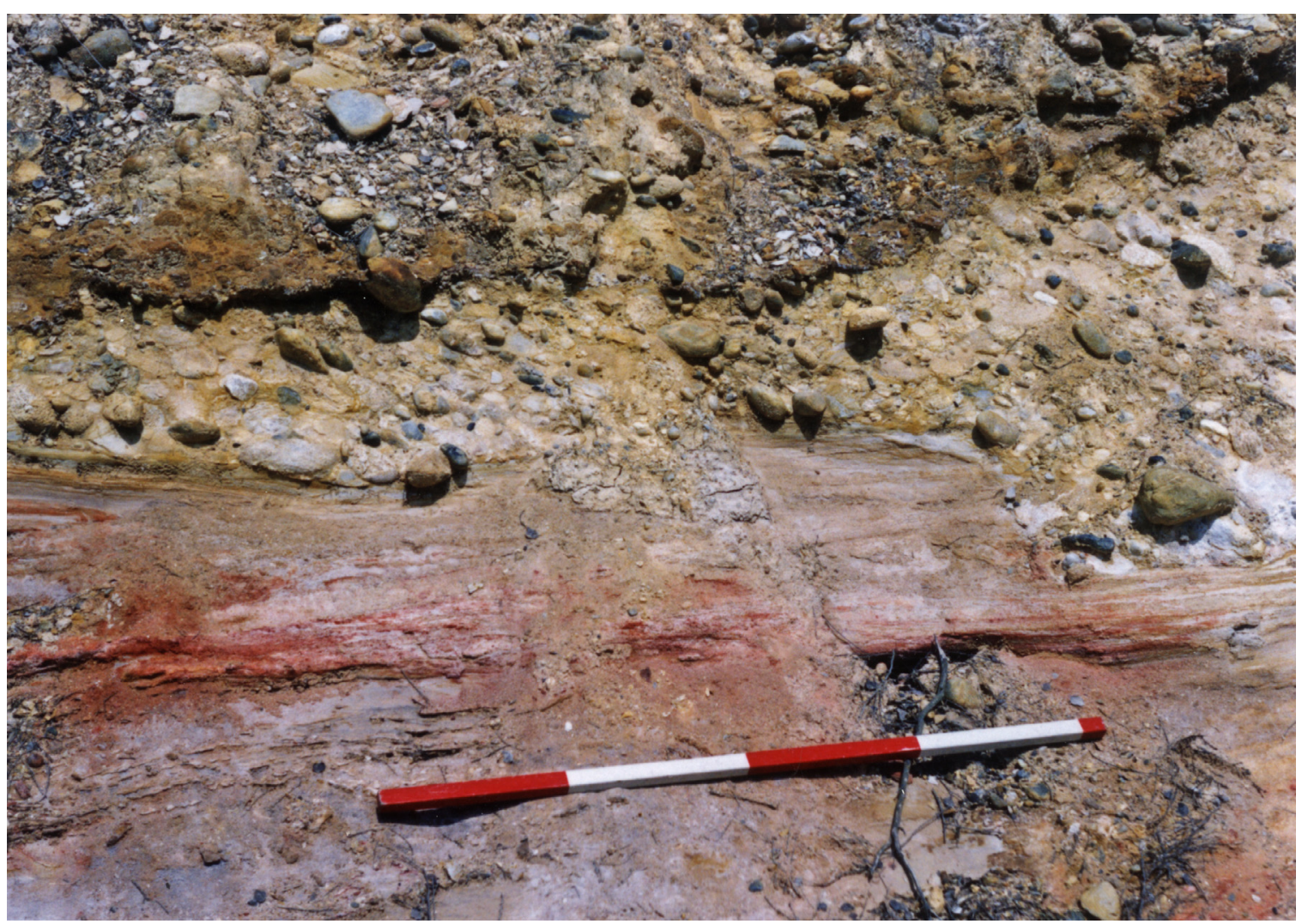

Figure 34B. Detail of contact, from far-right part of Fig. 34A. 


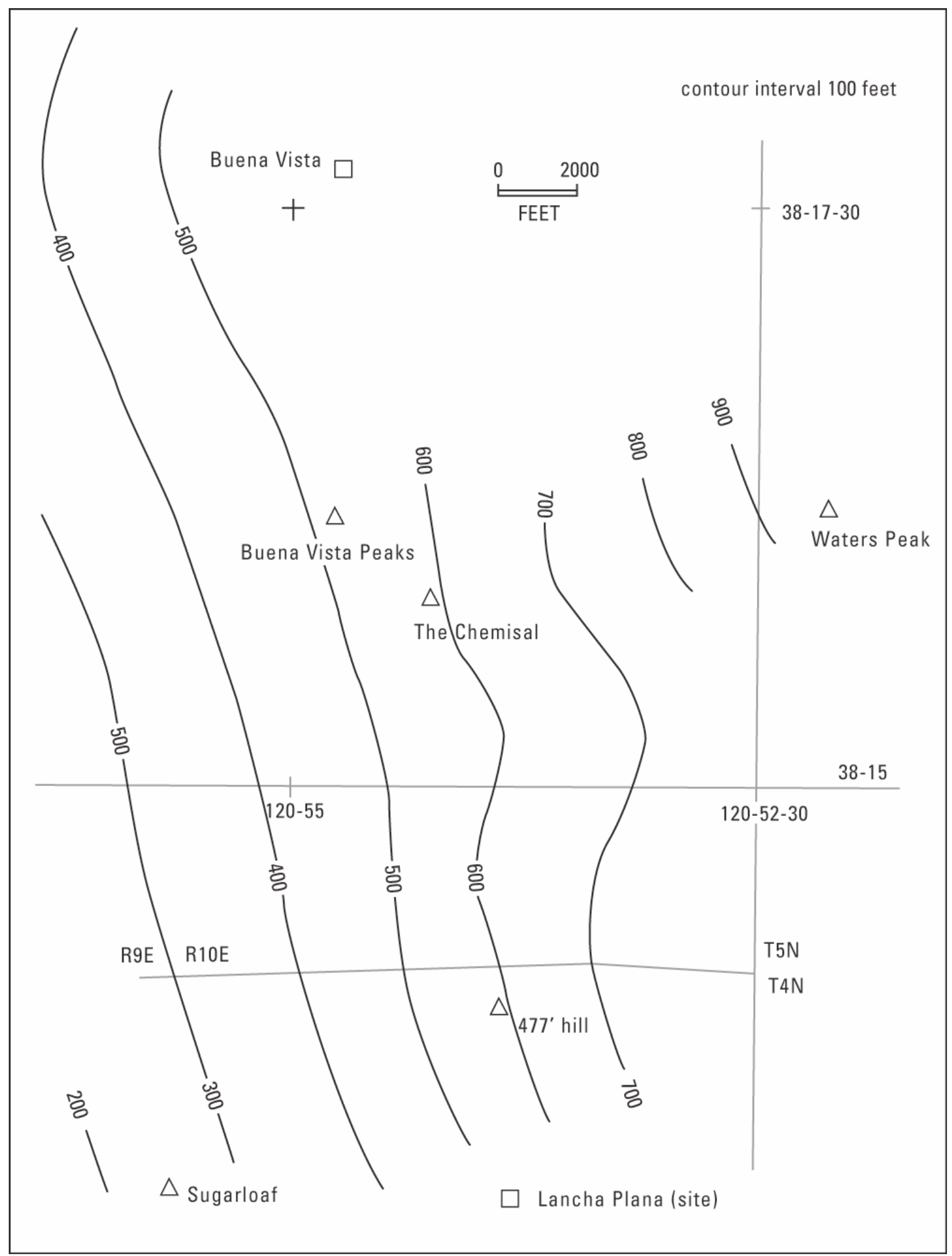

Figure 35. Structure-contour map on the top of the upper marine interval ("hard white sandstone") of the Ione Formation. 


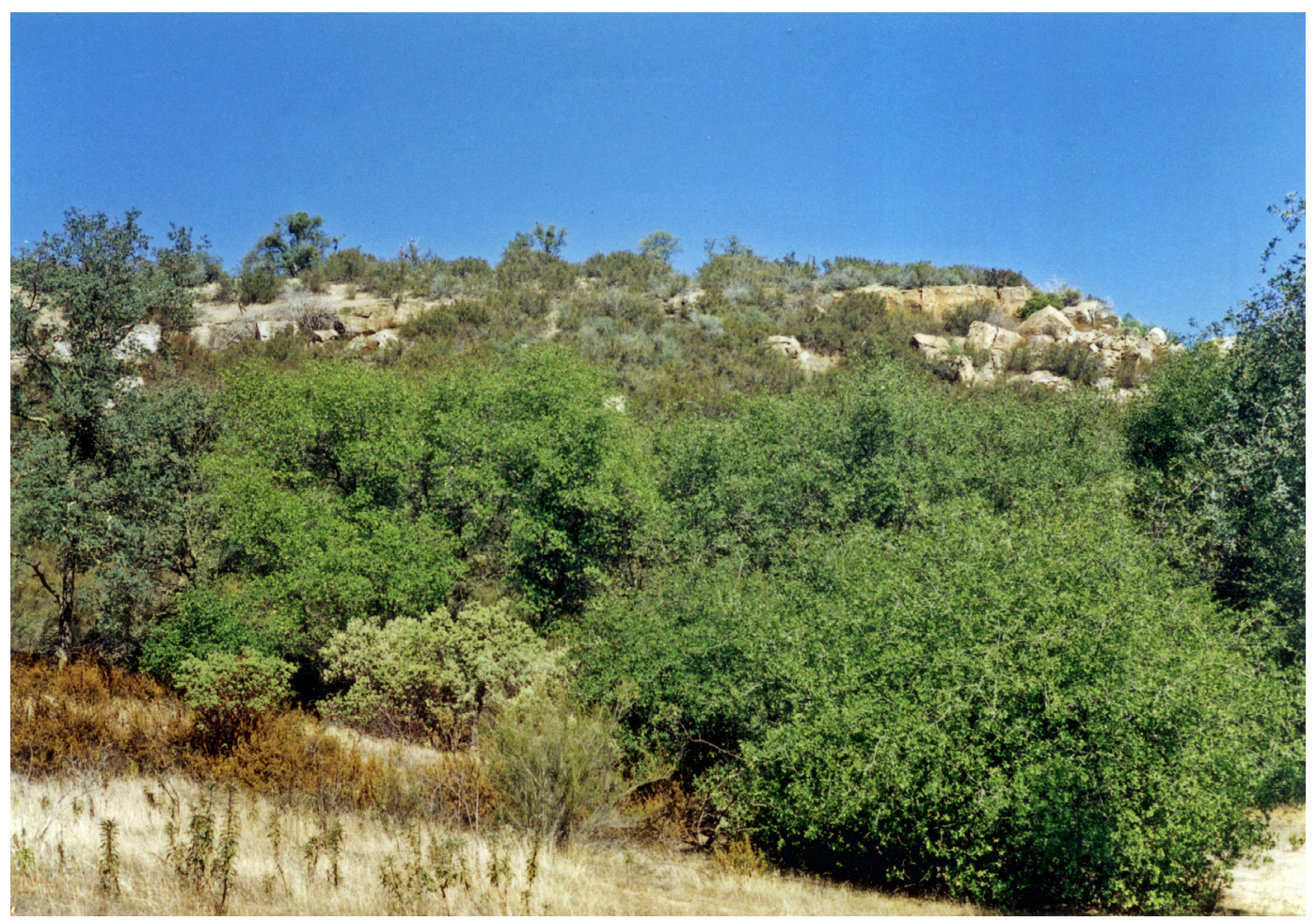

Figure 36. Mesa formed on "hard white sandstone", $1.4 \mathrm{mi}(2 \mathrm{~km}) \mathrm{SE}$ of Buena Vista Peaks. View north from Camanche Parkway North. Escarpment is approximately $100 \mathrm{ft}$. $(30 \mathrm{~m})$ high.

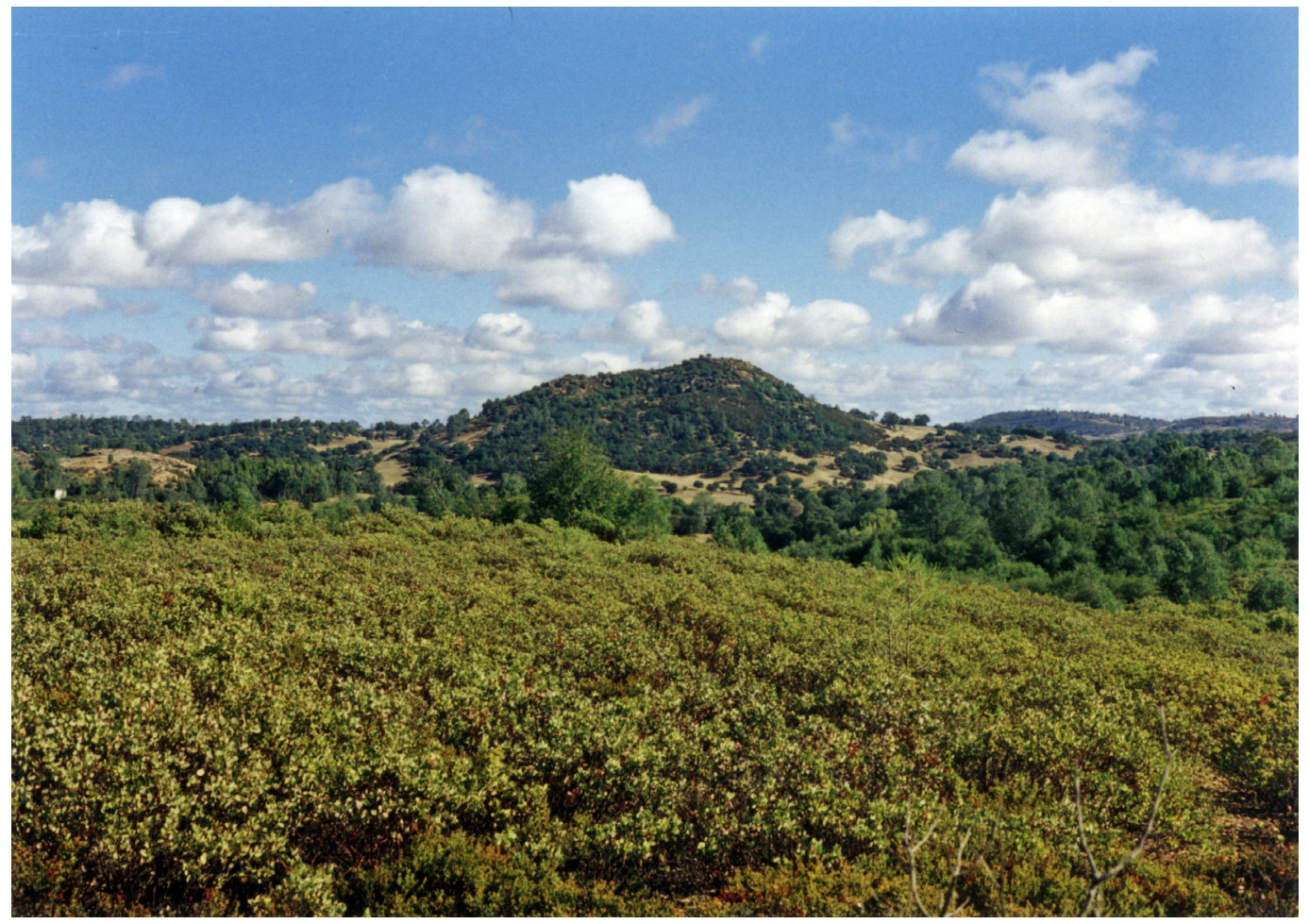

Figure 37. Waters Peak outlier, an erosion remnant of the Ione Formation ("hard white sandstone"), has an elevation of $950 \mathrm{ft}(290 \mathrm{~m})$ and about $450 \mathrm{ft}$ (135 m) of relief. View NE from Camanche Parkway North. 


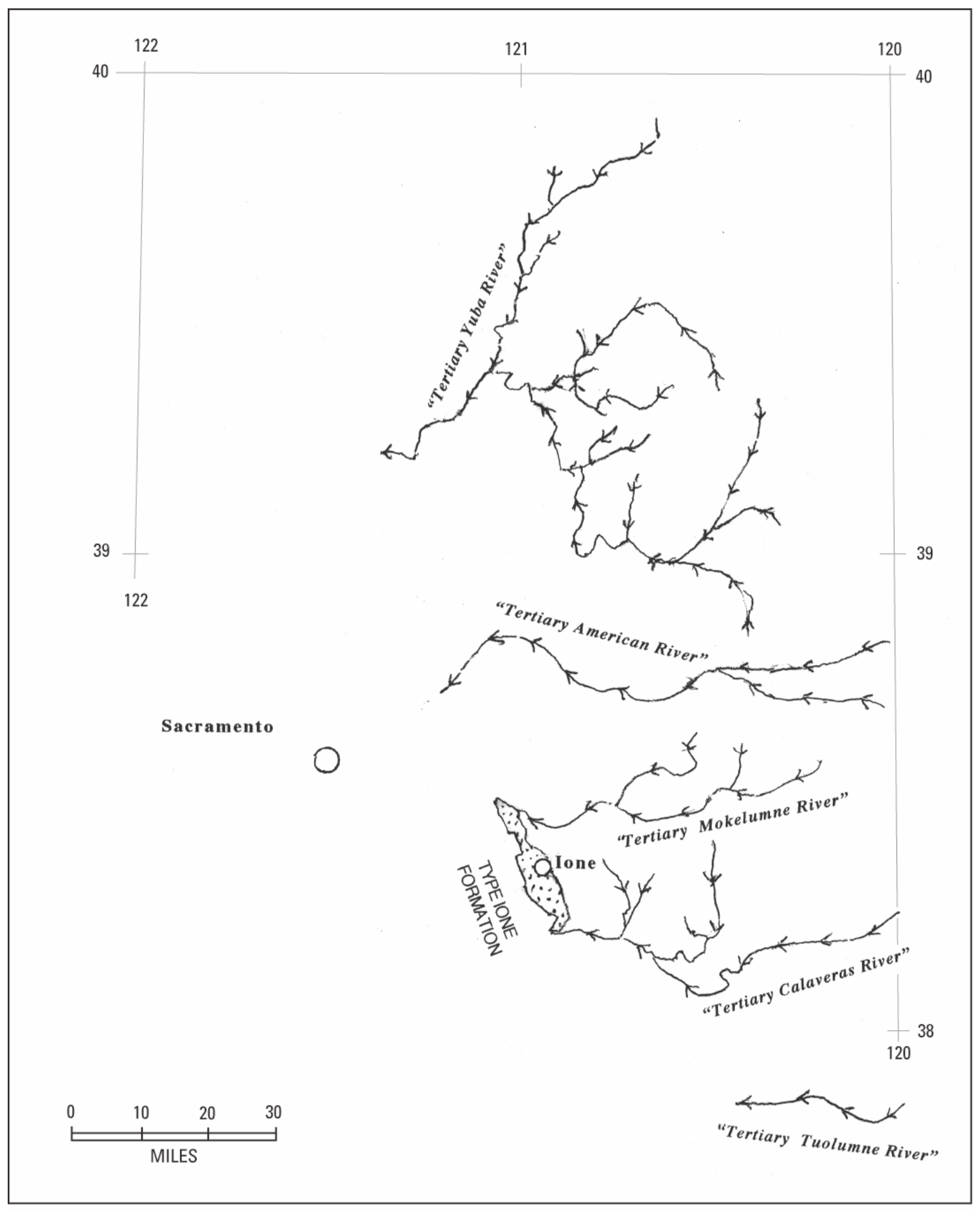

Figure 38. Paleogeographic map of the type area the Ione Formation relative to the northern Sierra Nevada, showing courses of major Tertiary (Eocene to Miocene) streams. Based on maps by Jenkins (1948) and by Bateman and Wahrhaftig (1966). 


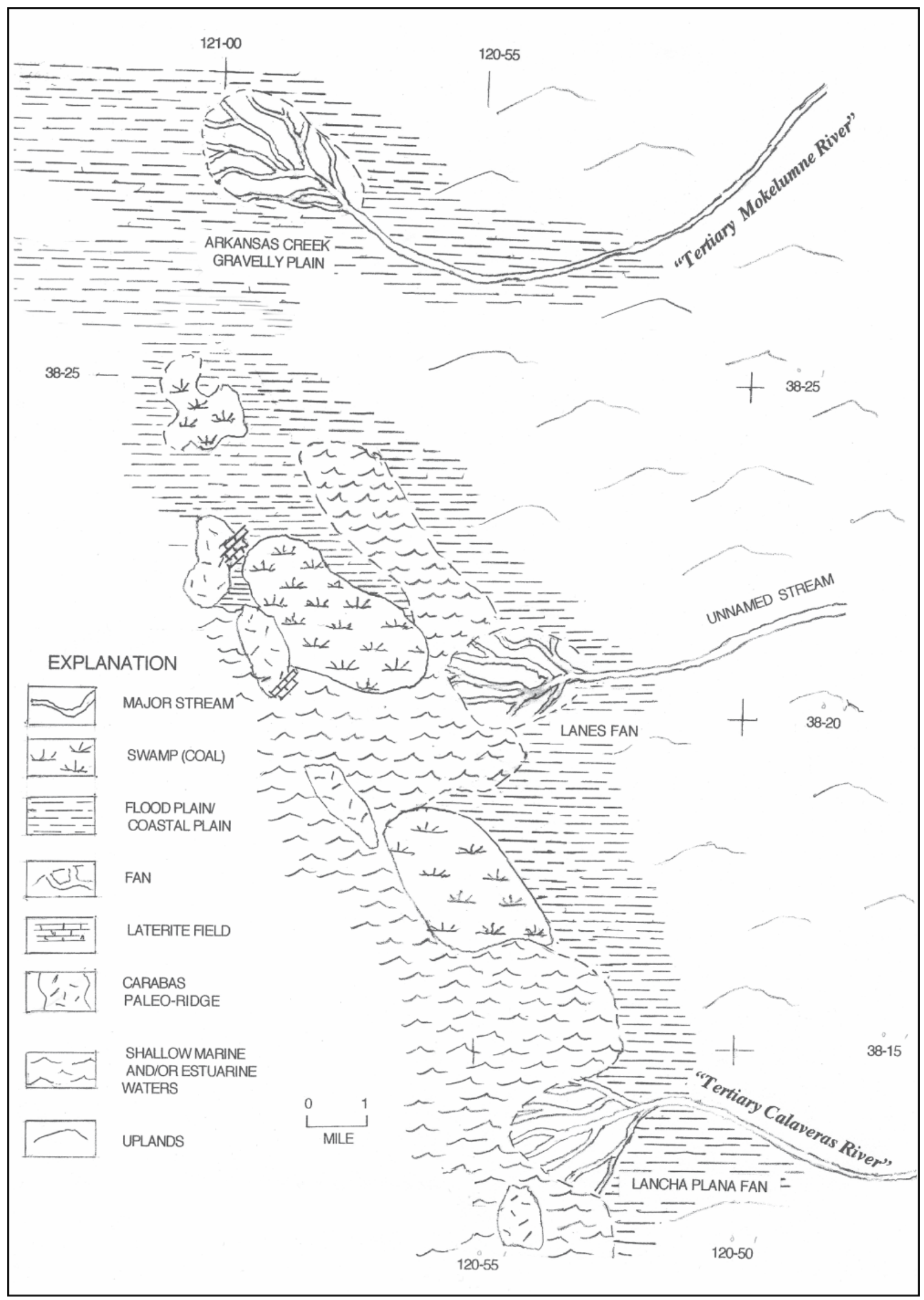

Figure 39. Hypothetical reconstruction of Eocene paleogeography of the type area of the Ione Formation during beginning of initial (lower) marine transgression. 